\title{
KÉTDIMENZIÓS RENDEZETT CINK-OXID NANOSTRUKTÚRÁK OPTIKAI ÉS FLUORESZCENCIÁS TULAJDONSÁGAI
}

\author{
Ábrahám Nóra \\ okleveles vegyészmérnök
}

Témavezető:

Dr. Dékány Imre

egyetemi tanár, az MTA rendes tagja

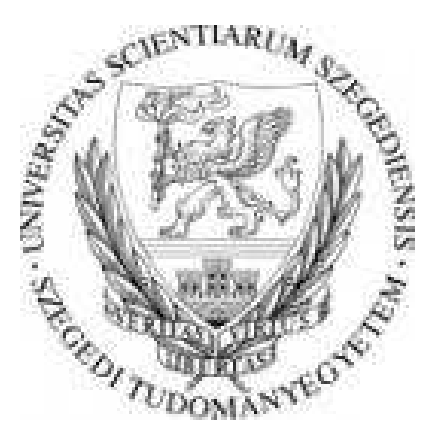

Szegedi Tudományegyetem, Fizikai Kémiai és Anyagtudományi Tanszék MTA-SZTE Szupramolekuláris és Nanoszerkezetű Anyagok Kutatócsoport Szeged, 2013 


\section{TARTALOMJEGYZÉK}

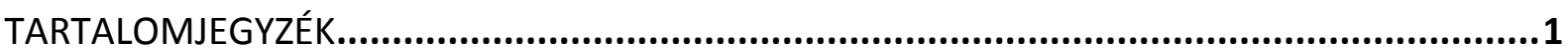

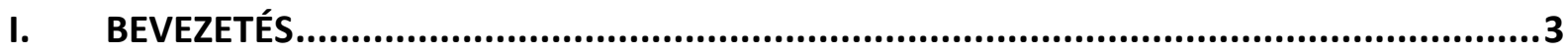

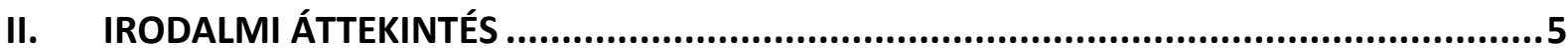

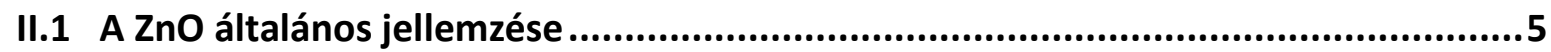

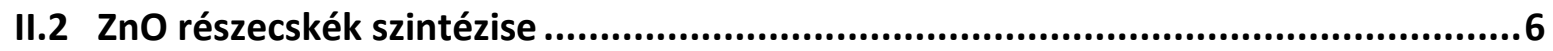

II.3 Nanoméretű ZnO részecskék optikai tulajdonságai ............................................9

II.3.1 Fluoreszcencia emissziós sajátságok ............................................................ 12

II.3.2 ZnO részecskék és filmek kölcsönhatása nemesfémekkel................................. 14

II.4 Nanorészecskék önszerveződése, rendezett struktúrák létrehozása ......................18

II.4.1 A Langmuir-Blodgett technika ............................................................... 21

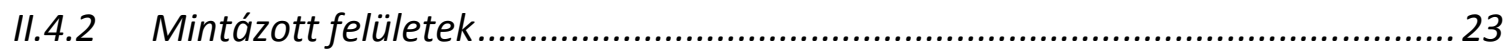

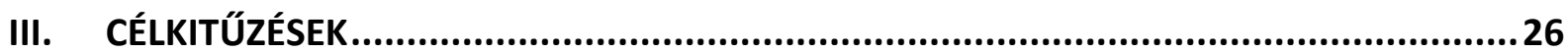

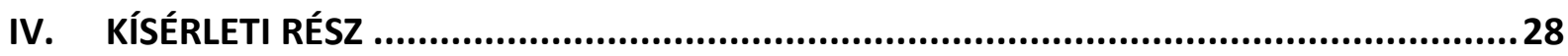

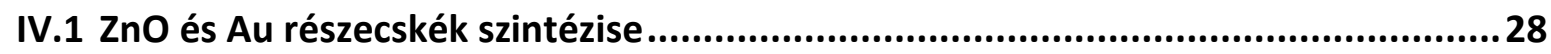

IV.1.1 ZnO részecskék elöállitása a 3-7 nm mérettartományban ...............................28

IV.1.2 Polietiléniminnel (PEI) stabilizált ZnO részecskék elöállitása ............................ 29

IV.1.3 ZnO részecskék elöállitása a 200-500 nm mérettartományban ..........................29

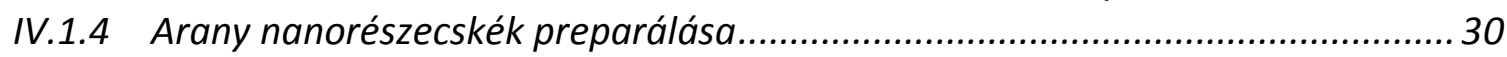

IV.2 Langmuir-filmek előállítása víz/levegő határfelületen ..........................................31

IV.3 Szilárd hordozós filmek készítése.......................................................................33

IV.3.1 Aranybevonatú hordozók készítése, felületkezelése ......................................... 33

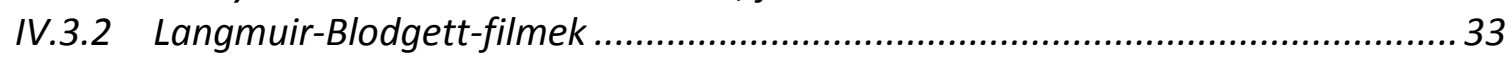

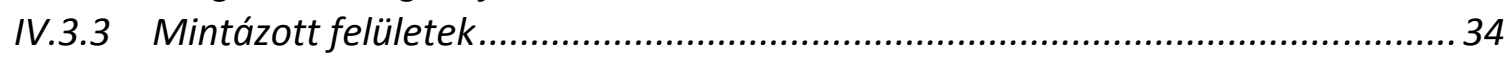

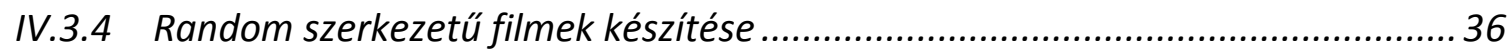

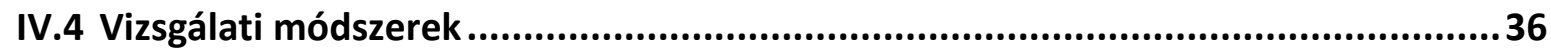

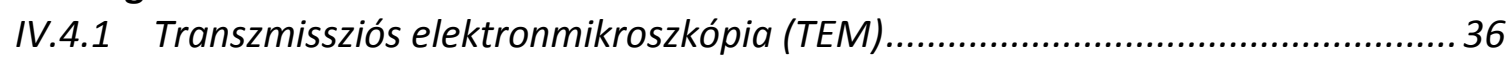

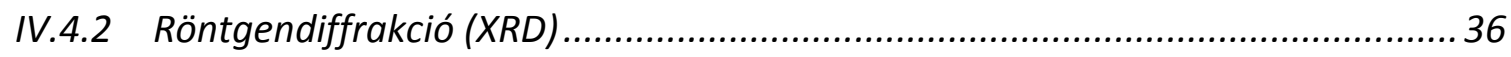

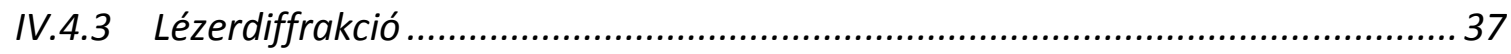

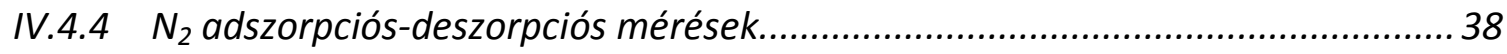

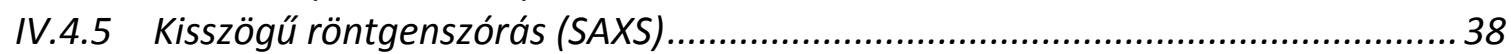

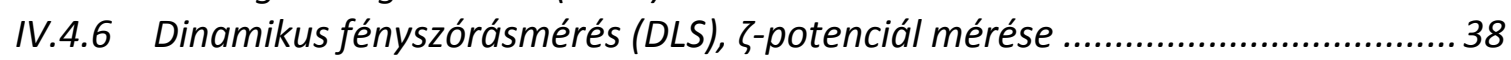

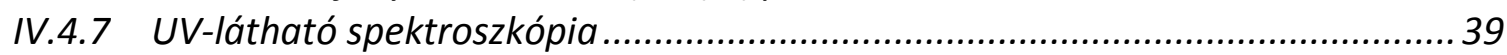

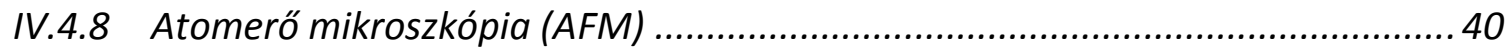

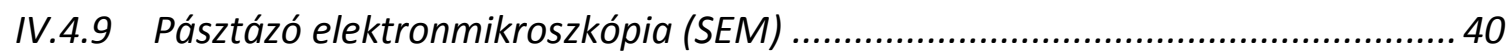

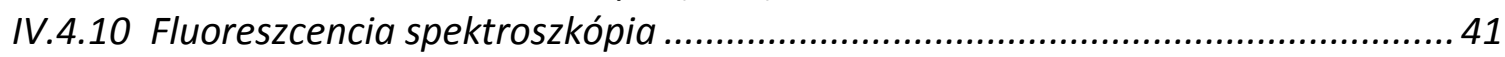


V. EREDMÉNYEK I. RÉSZ: 3-7 NM-ES CINK-OXID RÉSZECSKÉK ÉS FILMJEIK. 42

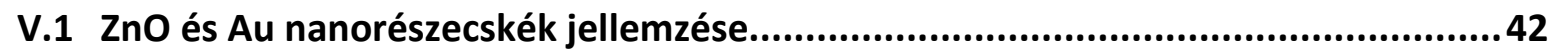

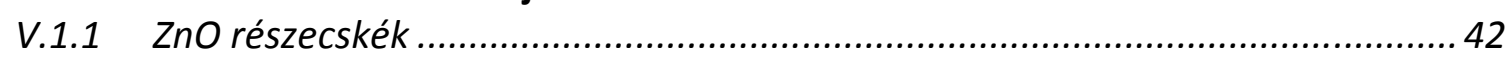

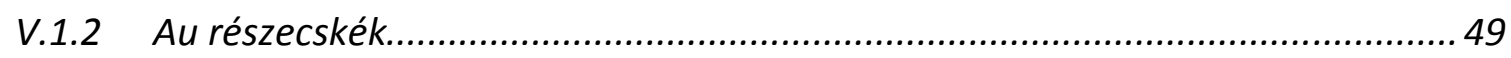

V.2 ZnO részecskék vízfelszíni Langmuir-filmjeinek vizsgálata .................................50

V.3 ZnO részecskék szilárd hordozós Langmuir-Blodgett-filmjeinek tulajdonságai .......51

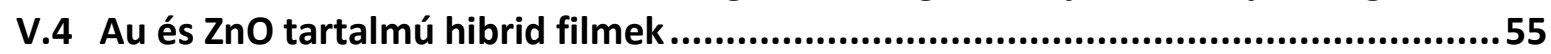

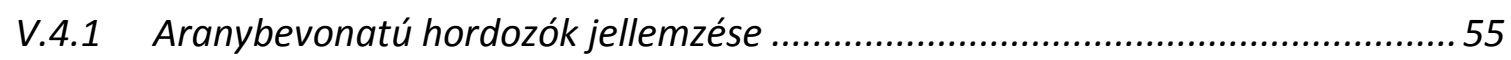

V.4.2 Au-ZnO hibrid filmek tulajdonságai................................................................56

VI. EREDMÉNYEK II. RÉSZ 200-500 NM-ES CINK-OXID RÉSZECSKÉK ÉS FILMJEIK ............63

VI.1 Monodiszperz, gömb alakú részecskék szintézise 200-500 nm

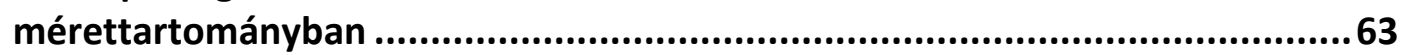

VI.2 200-500 nm-es $\mathrm{ZnO}$ részecskék jellemzése ..................................................64

VI.3 200-500 nm-es ZnO részecskék Langmuir-filmjeinek jellemzése ..........................69

VI.4 200-500 nm-es ZnO részecskék Langmuir-Blodgett-filmjeinek jellemzése .............71

VI.5 Mintázott felületek előállítása $341 \mathrm{~nm}$-es $\mathrm{ZnO}$ részecskékkel ...............................81

VI.5.1 Mintázatképzési paraméterek optimalizálása ............................................. 81

VI.5.2 ZnO részecskék mintázatainak jellemzése ...................................................... 84

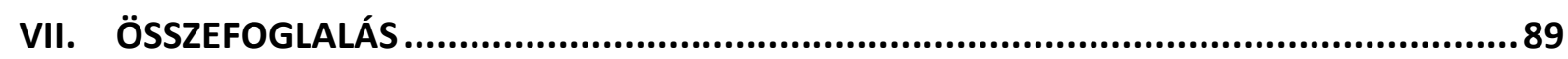

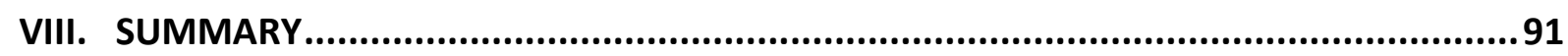

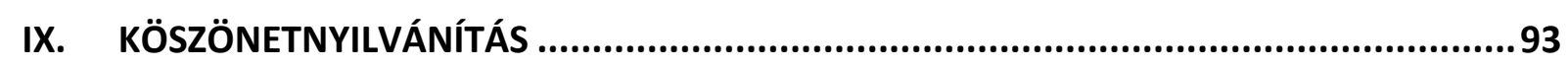

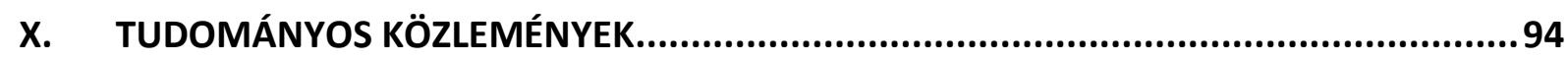

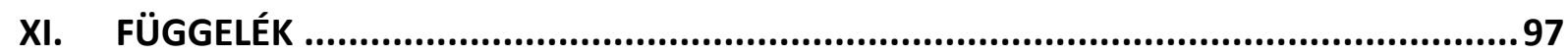

XI.1 Diszperz rendszerek kisszögű röntgenszórására vonatkozó általános összefüggések .......................................................................................99

XI.2 Nanorészecskés filmek fajlagos tömegének meghatározása abszorbancia kalibráció és elméleti számítás alapján..........................................................998

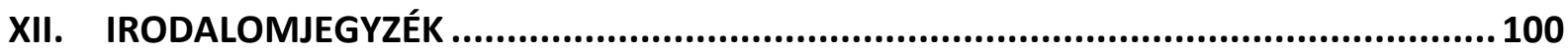




\section{BEVEZETÉS}

A nanotechnológia korunk egyik legdinamikusabban fejlődő és legintenzívebben kutatott tudományterülete. Az előrelépés az anyagszerkezeti vizsgálati módszerek jelentős fejlődésével, az anyag szerkezetét egyre kisebb léptékben vizsgálni képes új módszerek kidolgozásával vált lehetővé. A nanotechnológiai eljárások segítségével nanométeres méretü, különböző funkciókban müködtethető objektumok létrehozására vagyunk képesek. Ebben a mérettartományban megjelennek az anyagok méretkvantált fizikai jellemzői, ebböl adódóan a tömbfázisban mutatott tulajdonságokhoz képest a nanoszerkezetü anyagok újszerü optikai, elektromos, mágneses, stb. sajátságokkal rendelkeznek.

A nanoszerkezetű anyagok létrehozása és a tömbi fázistól eltérő tulajdonságaik minősítése az anyagtudományi kutatások középpontjában áll. A nanoméretű anyagokat tömbfázisú anyag bevonataként alkalmazva az eredeti tárgyat új, a szerkezeti tulajdonságokat meghaladó funkcióval láthatjuk el (például antireflexiós, öntisztuló vagy antibakteriális felületek). A nanorészecskék egyedi sajátságain túl meghatározó szerepe van annak, hogy milyen struktúrába rendezzük öket. Egy meghatározott rend esetén olyan új tulajdonsága jelenik meg az anyagnak, ami sem a tömbfázis, sem pedig a nanorészecskék szabálytalan struktúrája esetén nem figyelhető meg. Jó példa erre a fotonikus kristály, ahol a nanoléptékü periodikusságnak köszönhetően fotonikus tiltott sáv megjelenése figyelhető meg.

Munkám során rendezett, kétdimenziós filmek előállítását tűztem ki célul, amelyhez a gömb alakú és monodiszperz építőköveket $\mathrm{ZnO}$ részecskék szabályozott szintézisével valósítottam meg. A rendezett kétdimenziós filmek létrehozására többféle módszert is alkalmaztam: víz/levegő határfelületben Langmuir-filmeket késztettem, majd ezeket szilárd hordozóra vittem át a Langmuir-Blodgett technika segítségével. A Langmuir-Blodgett technika nagy előnye, hogy a szabályos részecskékből rétegenkénti építkezéssel pontosan szabályozható szerkezetű filmek hozhatók létre. A templát által irányított önrendeződéses filmképzési eljárással $\mathrm{ZnO}$ részecskék mintázatait sikerült létrehoznom. A részecskék önszerveződésén alapuló kolloidkémiai filmképzési eljárások nagyon egyszerü és olcsó utat biztosítanak különböző rendezettségű és felépítésű szilárd 
hordozós bevonatok létrehozására. Ilyen rendezett nanostrukturált filmek elönyösen alkalmazhatók például a szenzorika, a fotonika területén, de antireflexiós bevonatokként is funkcionálhatnak. 


\section{IRODALMI ÁTTEKINTÉS}

\section{II.1 A ZnO általános jellemzése}

A cink-oxid szilárd halmazállapotú fehér por, a természetben a hexagonális cinkit ásvány formájában található meg. Gyakran mangánnal vagy más elemekkel szennyezve fordul elő, amely sárga vagy vörös szín megjelenését eredményezi. A $\mathrm{ZnO}$ széleskörü alkalmazhatósága miatt meglehetősen elterjedt anyag. Az iparban a legnagyobb mennyiségben a gumigyártás során használják a vulkanizálási folyamat elösegítésére, valamint beton gyártása során a beton vízálló képességének növelésére. Antibakteriális hatásának köszönhetően számos kozmetikum tartalmazza, mint például testápolók, dezodorok és hintőporok, UV-elnyelőképessége miatt napvédő krémek fontos alapanyaga.

A cink-oxid amfoter vegyület. Vízben nagyon kis mértékben oldható, de savak és lúgok hatására könnyen oldódik [1]. A különböző oldott formák koncentrációját a pH függvényében az 1. ábra mutatja.

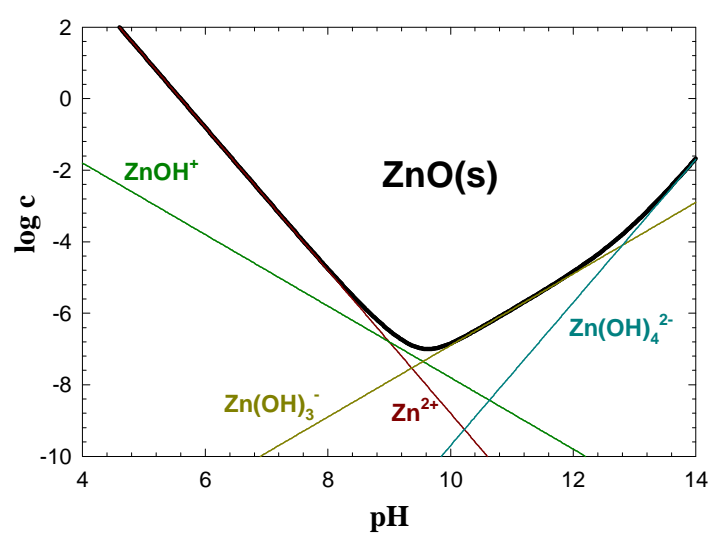

1. ábra. A ZnO oldhatósági diagramja [2].

A természetben előforduló kristályformája a hexagonális wurtzit kristályrács, de ismertek a köbös cink-blende és a kősó típusú kristályformák is, azonban ezek termodinamikailag nem stabilak [3]. 

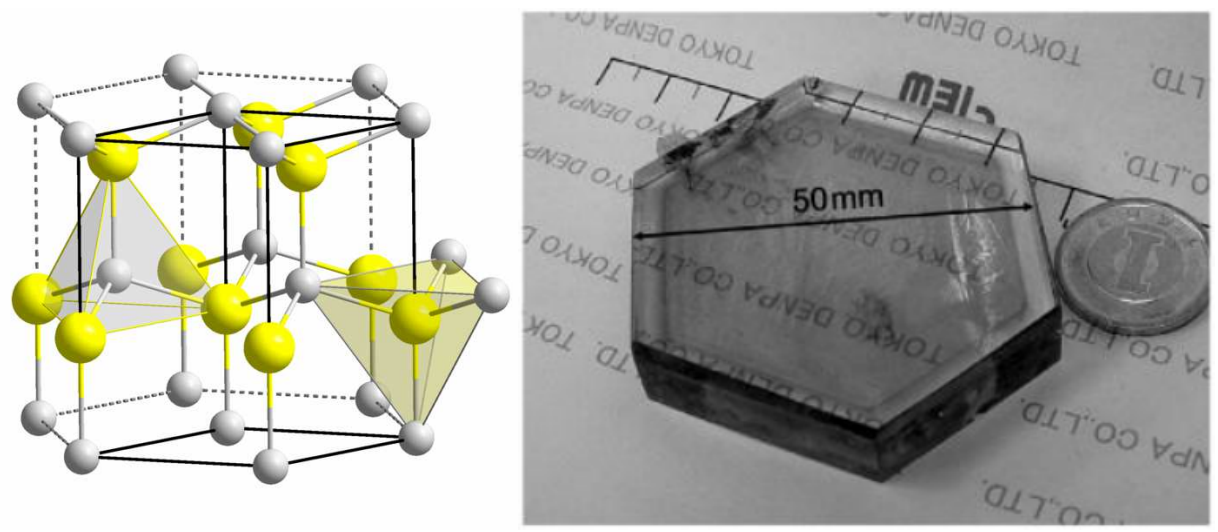

2. ábra. A hexagonális wurtzit kristályszerkezetü $\mathrm{ZnO}$ rácsmodellje, illetve egy hidrotermális eljárással növesztett $\mathrm{ZnO}$ egykristály [4].

$\mathrm{Az}$ anyagtudomány területén félvezető tulajdonsága miatt vizsgálják és alkalmazzák rendkívül elterjedten. A ZnO a kristályban lévő oxigén hibahelyek, vakanciák miatt természetes n-típusú félvezető. Számos előnyös tulajdonsággal bír, mint a jó fényáteresztő-képesség, az elektronok relatíve nagyfokú mobilitása, a széles tiltott sáv, a szobahőmérsékletü erős fotolumineszcencia, stb. [5].

\section{II.2 ZnO részecskék szintézise}

A cink-oxidot előnyös tulajdonságai miatt nagyon elterjedten használják a nanotechnológia területén, ennek megfelelően számos szintézismódszert dolgoztak ki a legalább egy dimenzióban nanométeres kiterjedésü $\mathrm{ZnO}$ részecskék szintézisére. Található eljárás vizes közegben $[6,7,8,9,10,11]$ illetve számos szerves oldószerben végzett szintézisre $[12,13,14,15]$, a részecskék mérete a néhány nm-től a több $\mu$ m-es méretig terjedhet, alakjuk pedig rendkívüli változatosságot mutat. Az irodalom áttekintése során olyan változatos morfológiájú $\mathrm{ZnO}$ részecskékkel találkozhatunk, amely azt az érzést keltheti, hogy szinte csak a fantázia szab határt a lehetőségeknek. Ennek demonstrálására összegyüjtöttem néhány általam érdekesebbnek talált példát (3. ábra). 

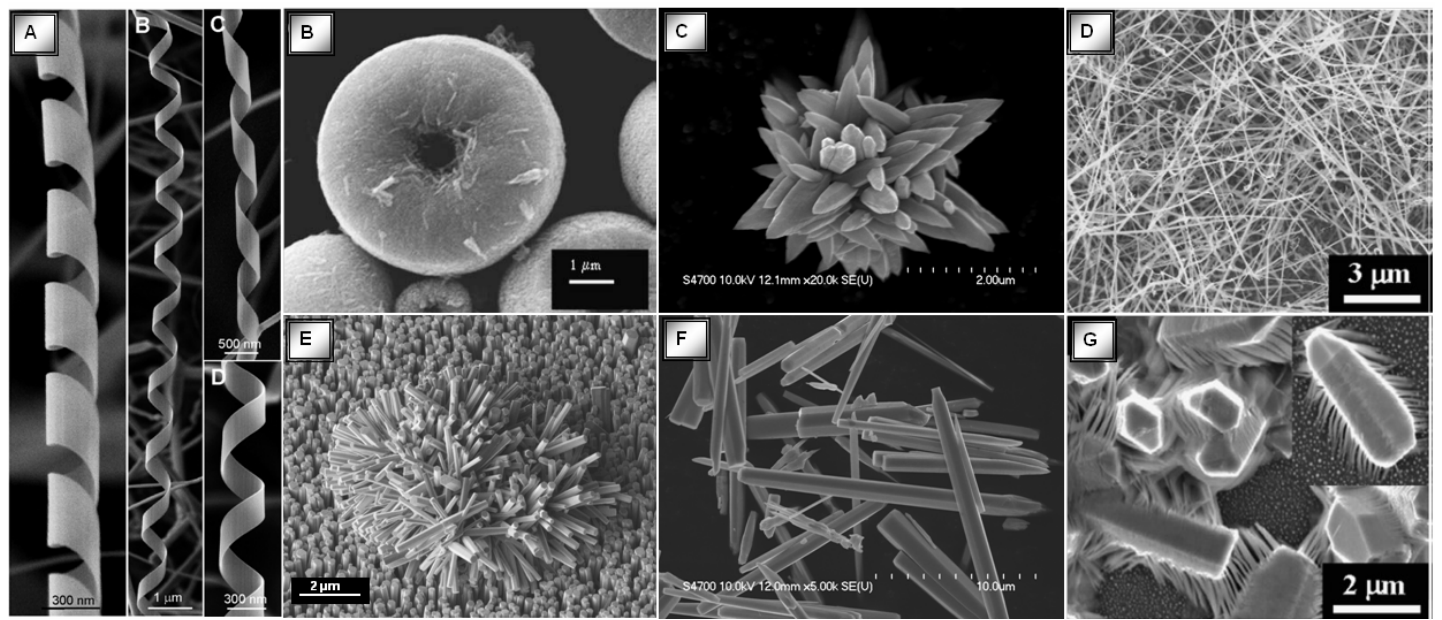

3. ábra. A szakirodalomban fellelhető néhány érdekesebb morfológiájú $\mathrm{ZnO}$ részecske: a) hélix [16], b) fánk [17], c) virág [6], d) szál [18], e) rúd [19], f) prizma [6], g) százlábú [18].

A szakirodalomban található számos szintézismódszer közül az általam alkalmazott egyik eljárást eredetileg Spanhel és Anderson [20] dolgozták ki, én a Meulenkamp által módosított változatot [21] adaptáltam. A Zn-acetát-dihidrát bázikus hidrolízisével etanolos közegben előállított 3 nm-es részecskék nem tökéletesen stabilak, a részecskeméret növekedése és lassú aggregáció is megfigyelhető a szolban. Az Ostwald-féle öregedésnek nevezett folyamat során a kisebb részecskék nagyobb oldhatóságuk (a görbületi sugár növekedésével nő az oldhatóság) miatt lassan feloldódnak, az oldat telítettsége miatt kiváló anyag pedig a nagyobb részecskék felszínére rakódik. Ez a folyamat alacsony hőmérsékletủ tárolással, illetve stabilizáló szerek adagolásával annyira lelassítható, hogy a szolok néhány hónapig kinetikailag stabilak maradnak.

Az irodalomban található néhány munka, amelyekben az általam használt eljárással (esetleg kisebb módosításokkal) szintetizált $\mathrm{ZnO}$ részecskék öregedését tanulmányozták. Meulenkamp [21] a hőmérséklet, az elektrolitok és a szolok mosásának (többszöri kicsapás, centrifugálás és újradiszpergálás) hatását vizsgálta a részecskeméretre. Azt találta, hogy a szolok mosása és az alacsony hőmérsékletü $\left(\sim 4^{\circ} \mathrm{C}\right)$ tárolás lassítja, különböző koncentrációban adagolt elektrolitok pedig gyorsítják a részecskeméret növekedését. Sun és munkatársai [22] Meulenkamp eredményei alapján egy tisztítási eljárást dolgoztak ki, amely megakadályozza a szolok öregedését. A szolok 2 hónap elteltével sem mutattak jelentős öregedést ha a mosás után hexán - metanol 1:7 illetve 1:3 arányú elegyében diszpergálták a részecskéket és a szolt azután alacsony hőmérsékleten tárolták. 
Több publikáció is található az irodalomban, amelyekben valamilyen felületmódosító szer alkalmazásával megpróbálták lassítani az öregedési folyamatot. Egyesek a kész szolhoz adagolják a stabilitás növelésére szánt komponenst [23, 24, 25], mások a felületmódosító anyag jelenlétében végzik a részecskék szintézisét [26, 27, 28, 29]. A felületmódosításhoz legelterjedtebben a különböző szilanizáló ágenseket [23, 24] és polielektrolitokat, mint a PEI (polietilénimin) [28] és a PVP (polivinilpirrolidon) [24, 26, 27, 29] alkalmazzák, de található példa egyéb anyagokra is: 1-dekántiol [27], dietanolamin [30] vagy trietanolamin [31]. Wu és munkatársai [24] öt különböző anyag hatását vizsgálták. Arra az eredményre jutottak, hogy a 3-aminopropil-trimetoxiszilán, a tetraetilortoszilikát és a merkaptoszukcinsav alkalmazásával sikeresen beborítható a részecskék felülete és valamelyest lassul a szolok öregedése, azonban a 3-merkaptopropil-trimetoxiszilán és a PVP adagolásával a szolban nagyobb agglomerátumok, klaszterek kialakulását figyelték meg.

A monodiszperz részecskék szintézisének fontossága a speciális felhasználhatósági lehetőségeikben mutatkozik meg: az egyforma méretü részecskékből pontosan szabályozható módon állíthatók elő -optikai tulajdonságok szabályzására is alkalmastervezhető felépítésü nanostruktúrák.

Az irodalomban található számos szintézismódszer közül csak néhány olyat lehet találni, amelyek valóban monodiszperz $\mathrm{ZnO}$ részecskéket eredményeznek. Vizes közegben szintetizáltak egyforma méretü részecskéket Chittofratti és munkatársai [32], Zhong és munkatársai [33], valamint Jiang és munkatársai [34]. Inoguchi és szerzőtársainak [35] egy mikroemulziós eljárással sikerült monodiszperz részecskéket előállítani.

Szűk méreteloszlású, gömb alakú fém és fémoxid részecskék szintézise sikeresen kivitelezhető poliol közegben [36, 37, 38]. Jezequel és munkatársai [39] számoltak be elsőként monodiszperz $\mathrm{ZnO}$ részecskék előállításáról 200-400 nm mérettartományban dietilén-glikolos közegben. Számos reakcióparaméter hatását vizsgálták a képződő részecskék méretére, úgymint a víz koncentrációja, az oldószer anyagi minősége, a prekurzor só koncentrációja, a reakció hőmérséklete és a felfütési sebesség. Tapasztalataik szerint a víz jelenléte elengedhetetlen a részecskék képződéséhez, az optimális mennyiséget $\mathrm{H}_{2} \mathrm{O} / \mathrm{Zn}^{2+}=2$ mólaránynál találták (ennek megfelelően kristályvizes Znacetátot alkalmaztak: $\left.\mathrm{Zn}\left(\mathrm{CH}_{3} \mathrm{COO}\right)_{2} \times 2 \mathrm{H}_{2} \mathrm{O}\right)$. A vizsgált oldószerek közül a szabályos, gömb alakú részecskék képzéséhez a dietilén-glikolt találták legmegfelelöbbnek. A 
megfelelő méretű (szubmikronos) részecskék maximum $0,18 \mathrm{~mol} / \mathrm{dm}^{3}$ sókoncentráció mellett keletkeztek. A részecskék méretének szabályozását a felfütési sebesség változtatásával valósították meg.

Seelig és munkatársai [40] egy kétlépéses eljárással állítottak elő monodiszperz, gömb alakú $\mathrm{ZnO}$ részecskéket. Az első lépésben kapott polidiszperz szol centrifugálása után a felülúszó bizonyos részletét a második reakcióelegyhez adagolták. A képződőtt részecskék méretét a második lépésben hozzáadott felülúszó mennyiségének változtatásával 100-600 nm mérettartományban tudták hangolni.

Tay és munkatársai [41] a dietilén-glikolos közegü $\mathrm{ZnO}$ részecskék képződési mechanizmusát vizsgálták. Megállapították, hogy a részecskék individuálisan instabil primer kristályok, kolloid alegységek aggregációjával jönnek létre. Az alegységek gömb alakú aggregátuma esetén a felületi szabadenergia minimuma, ezáltal a legnagyobb stabilitás valósul meg.

\section{II.3 Nanoméretü ZnO részecskék optikai tulajdonságai}

A $\mathrm{ZnO}$ nanorészecskék jellemzőinek, a méretkvantált effektusnak köszönhetően megjelenő új tulajdonságainak felderítése az utóbbi időben nagy hangsúlyt kapott [3, 42, 43, 44, 45]. A témában meglehetősen nagyszámú kísérleti munka született, ennek köszönhetően nehéz az eredmények teljes és szisztematikus tárgyalása. Erre a feladatra nem is vállalkoznék, inkább azokat a fontosabb szempontokat, eredményeket emelem ki, amelyek a dolgozat szempontjából leginkább relevánsak.

Ahogyan korábban már említettem a $\mathrm{ZnO}$ félvezető tulajdonságú. A félvezetők fajlagos vezetőképessége definíció szerint $10^{-9}$ és $10^{3} \Omega^{-1} \mathrm{~cm}^{-1}$ közti tartományban van, jellemzőjük, hogy a vezetést elektronok (nem ionok) közvetítik, illetve a hőmérséklettel csökken az ellenállásuk. A vezetők, szigetelők és félvezetők elkülönítését legjobban az elektronszerkezetüket leíró sávmodell alapján lehet szemléltetni. Kristályos anyagok esetén a kristályban található elektronok csak bizonyos intervallumrendszerbe eső energia értékeket vehetnek fel, ez az ún. sávszerkezet (4. ábra). Félvezetők esetén az elektronokat viszonylag kis energiaközléssel gerjeszthetjük a vezetési sávba, közben maguk után hagynak egy lyukat, amely pozitív töltésü részecskeként viselkedik. Ezek az elektron-lyuk párok felelősek a vezetés létrejöttéért. Félvezetőkben a kristály termikus energiája 
elegendő ahhoz, hogy az elektronok leküzdjék a tiltott sáv általi küszöböt és a vezetési sávba kerüljenek, azaz megvalósuljon a töltésszeparáció.

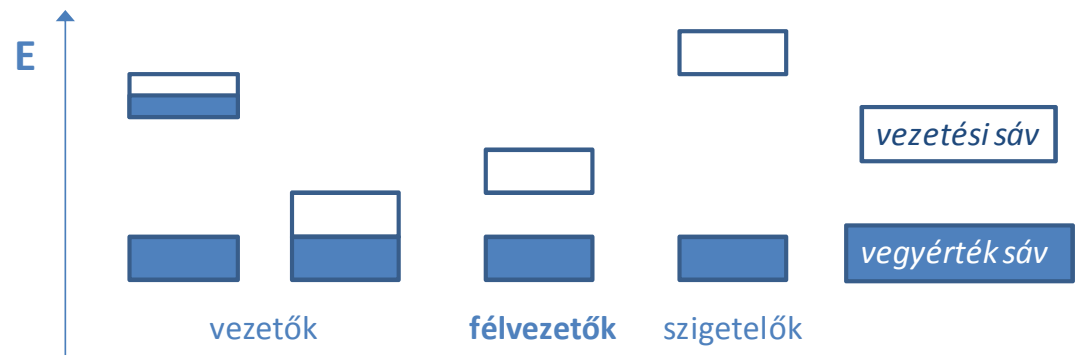

4. ábra. A kristályos anyagok sávelmélete: vegyérték és vezetési sávok relatív helyzete vezetők, félvezetők és szigetelők esetén.

A ZnO vegyület félvezető, a kristályban relatíve nagy hézagok találhatók, amely lehetőséget ad rácsközi atomok beépülésére. Hőkezelés hatására oxigén atomok lépnek ki a rácsból. A kristályban lévő oxigén vakanciáknak és a rácsközi cink atomoknak köszönhetően n-típusú félvezető, tehát a többségi töltéshordozók az elektronok. A tömbfázisú ZnO-ra jellemző tiltott sáv ('band gap') szélessége 3,37 eV [46], a szabad töltéshordozók kötési energiája viszonylag magas, $60 \mathrm{meV}$ [46], ami az optoelektronikai felhasználások szempontjából előnyös.

Ha a ZnO-ot a tiltott sáv szélességét meghaladó energiájú fénnyel világítjuk meg, akkor a fény egy részét elnyeli. Az abszorpcióhoz szükséges minimális energiát gerjesztési küszöbenergiának nevezik (tulajdonképpen megegyezik a tiltott sáv energiájának nagyságával, mindössze megközelítésbeli különbségről van szó). A 3,37 eV gerjesztési küszöbenergia 368 nm hullámhosszú fénynek felel meg, tehát a ZnO elnyelési spektrumán ennél kisebb hullámhosszaknál várható elnyelés.

Ismert, hogy a félvezető részecske méretének csökkentésével elérhetünk egy tartományt, amelyben megjelenik az ún. méretkvantálási hatás, azaz ebben a tartományban a részecskék tulajdonságai méretfüggőek és eltérnek a tömbi fázisra jellemzőektől. Ez a mérettartomány a szabadon mozgó törtéshordozók (excitonok) átlagos távolságával van összefüggésben, amelyet az excitonok Bohr sugarának nevezünk. A méretkvantálási hatás tulajdonképpen a töltéshordozók szabad mozgásának korlátozódása miatt jön létre. A korlátozás dimenzióinak száma alapján megkülönböztethetünk kvantumhullámokat (QW, quantum well), kvantumszálakat (QWR, quantum wire) és kvantumpöttyöket (QD, quantum dot), amelyeknél a szabad mozgást lehetővé tevő dimenziók száma rendre 2, 1, 
illetve 0. A $\mathrm{ZnO}$ esetén az excitonok Bohr sugara 2,34 nm [47], ezért ebben a nagyságrendben várható a méretfüggő hatások megjelenése.

A félvezetők egyik legfontosabb jellemzője a tiltott sáv szélessége. A gerjesztési küszöbenergia (tiltott sáv szélessége) UV-látható abszorbancia spektrumok kiértékelésével, mérések útján meghatározható, de elméleti megfontolások alapján számítható is.

Többféle módszert használnak a gerjesztési küszöbenergia UV-látható abszorbancia spektrumokból történő meghatározására, a legelterjedtebb a Tauc módszer [48]:

$$
(\alpha h v)^{2}=A \cdot\left(h \cdot v-E_{g}\right),
$$

ahol $\alpha$ az abszorpcós koefficiens, $A$ konstans, $h v$ a fotonenergia $(\mathrm{eV}) . \mathrm{Az}(\alpha h v)^{2}$ vs. $(h v)$ függvény lineáris részére illesztett egyenes és az abszcissza metszéspontja adja meg a gerjesztési küszöbenergia értékét. Egy másik, egyszerü, praktikus és megbízható eredményt adó megoldás, ha a gerjesztési küszöbenergiát azzal a hullámhosszú fénnyel azonosítjuk, amelynél az abszorbancia fele az abszorpciós csúcsnál mért értéknek $\left(\lambda_{1 / 2}\right)$ [21].

A részecskemérettől függő tiltott sáv szélességének $\left(E_{g}, e V\right)$ elméleti számításához ZnO esetén klasszikusan a Brus [49] által levezetett egyenletet alkalmazzák:

$$
E_{g}=E_{g}^{t o ̈ m b i}+\frac{h^{2}}{8 R^{2}}\left(\frac{1}{m_{e}}+\frac{1}{m_{h}}\right)-\frac{1,8 e^{2}}{4 \pi \varepsilon \varepsilon_{0} R}+\text { kisebb tagok, }
$$

ahol $E_{g}$ a részecske gerjesztési küszöbenergiája, $E_{g}{ }^{\text {tömbi }}$ a tömbi fázisra jellemző gerjesztési küszöbenergia, $h$ a Planck-állandó, $R$ a részecske sugara, $m_{e}$ az elektron effektív tömege, $m_{h}$ a lyuk effektív tömege, $e$ az elektron töltése, $\varepsilon$ a félvezetö relatív dielektromos állandója, $\varepsilon_{O}$ pedig a vákuum dielektromos állandója. A fenti kifejezés alapján a tiltott sáv szélesedését a részecskeméret függvényében két részre lehet bontani [50]:

$$
\begin{gathered}
E(e)=E_{g}+\frac{h^{2}}{8 m_{e} R^{2}}-\frac{0,9 e^{2}}{4 \pi \varepsilon \varepsilon_{0} R}, \\
E(h)=\frac{h^{2}}{8 m_{h} R^{2}}-\frac{0,9 e^{2}}{4 \pi \varepsilon \varepsilon_{0} R},
\end{gathered}
$$

ahol $E(e)$ és $E(h)$ a vezetési- és a vegyérték sávok szélső energia értékeit jelölik. A két kifejezés közt a töltéshordozó részecskék tömegében van különbség, ezek értéke határozza meg az eltérő méretfüggő energiaszint-eltolódást. 


\section{II.3.1 Fluoreszcencia emissziós sajátságok}

A szakirodalomban széleskörüen tanulmányozzák a különböző módszerrel előállított ZnO nanostruktúrák (részecskék, filmek) fluoreszcencia emissziós sajátságait. Az emissziós spektrum jelentős mértékben függ az előállítási körülményektől, de legtöbbször egy UV és egy látható tartományba eső emisszió jelenik meg [42, 51, 52, 53]. Az UV emisszió (amelyet általában exciton emissziónak neveznek) a fény által gerjesztett töltéshordozók direkt rekombinációjának eredménye. A látható tartományba eső emissziót általában a felületi hibahelyeken csapdázott elektronoknak köztes energiaszinteken történő relaxációjával magyarázzák (5. ábra).

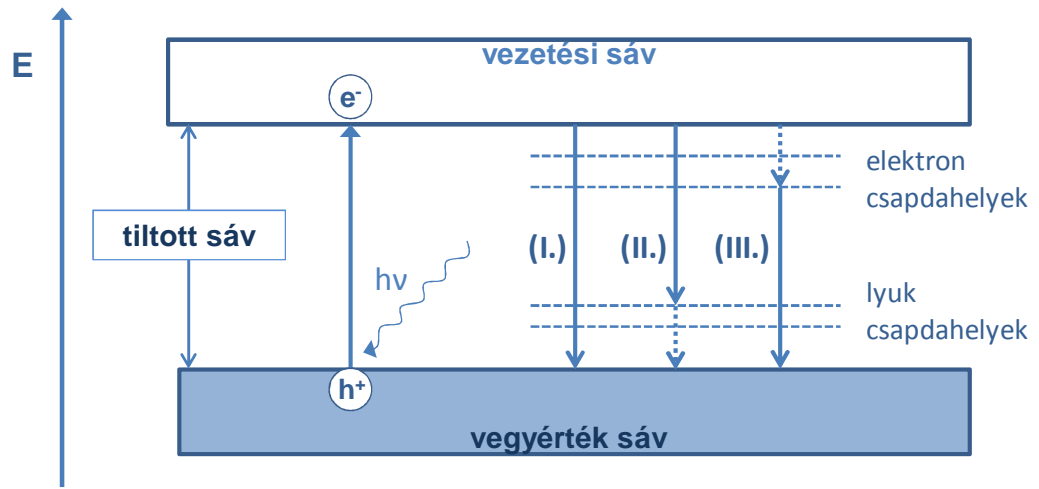

5. ábra. A ZnO emissziós folyamatainak szemléltetése az energiaszintek tükrében: (I.): direkt rekombináció, (II.) és (III.): relaxálás felületi hibahelyeken keresztül.

Habár a látható emisszió pontos magyarázata nem ismert, egyértelműnek látszik a felületi hibahelyek fontos szerepe, amelyek közül a legtöbb szerző az oxigén hibahelyeket említi meg [53, 54, 55], de más hibahelyek említése is előfordul: cink vakanciák [56], rácsközi oxigén atomok [57], rácsközi cink atomok [58] és az ún. 'antisite oxygen' [59], azaz a $\mathrm{Zn}$ rácspontban lévő $\mathrm{O}$ atom. A $\mathrm{ZnO}$ kristályokban a meghatározó hibahelyek a rácsközi cink atomok, illetve az oxigén vakanciák, amelyek donor hibahelyek, a cink vakanciák pedig akceptor hibahelyek. Az egyes hibahelyekhez tartozó energiaszintekre történtek becslések $[60,61]$, azonban viszonlag nagy különbségek vannak egyes szerzők eredményei közt.

Az említett két relaxációs folyamat egymással versengő folyamatok. Az UV és a látható emisszió helye és intenzitása függ a részecskemérettől [62], a kémiai összetételtől (esetlegesen hozzáadott szennyezők) [6,12] illetve a részecskék kémiai környezetétől 
(adszorbeált anyagok, oldószer molekulák) [63]. A részecskemérettől függő emisszió a tiltott sáv méretfüggésének eredménye. A Brus [49] által megadott, tiltott sáv meghatározására vonatkozó egyenlet két részre bontásával [50], a (3) és (4) egyenletek szerint megadható a vegyérték és vezetési sávok széleihez tartozó energia értékek a részecskeméret függvényében (6. ábra). Dijken és munkatársai [50] feltételezték, hogy a hibahelyek energiaszintje állandó, a részecskemérettől nem függ. Az emissziós maximum energiájának a mérettől függő változását összevetették a vegyérték és a vezetési sávok széleinek méretfüggésével, és úgy gondolták, hogy a meghatározó folyamat tendenciája meg fog egyezni az emissziós maximumnál mért tendenciával, így az az energiaszint részt vesz az emissziós folyamatban. Ebböl azután következtethetnek arra, hogy elektron vagy lyuk csapdahelyekhez köthető a látható emisszióhoz vezető relaxáció. Eredményeik a lyuk csapdahelyek meghatározó szerepére mutattak (6. ábra A). Zhang és munkatársai [54] méréseiket hasonló módon kiértékelve ellentétes eredményre jutottak: az elektron csapdahelyeken keresztül jön létre a látható emisszió (6. ábra B).
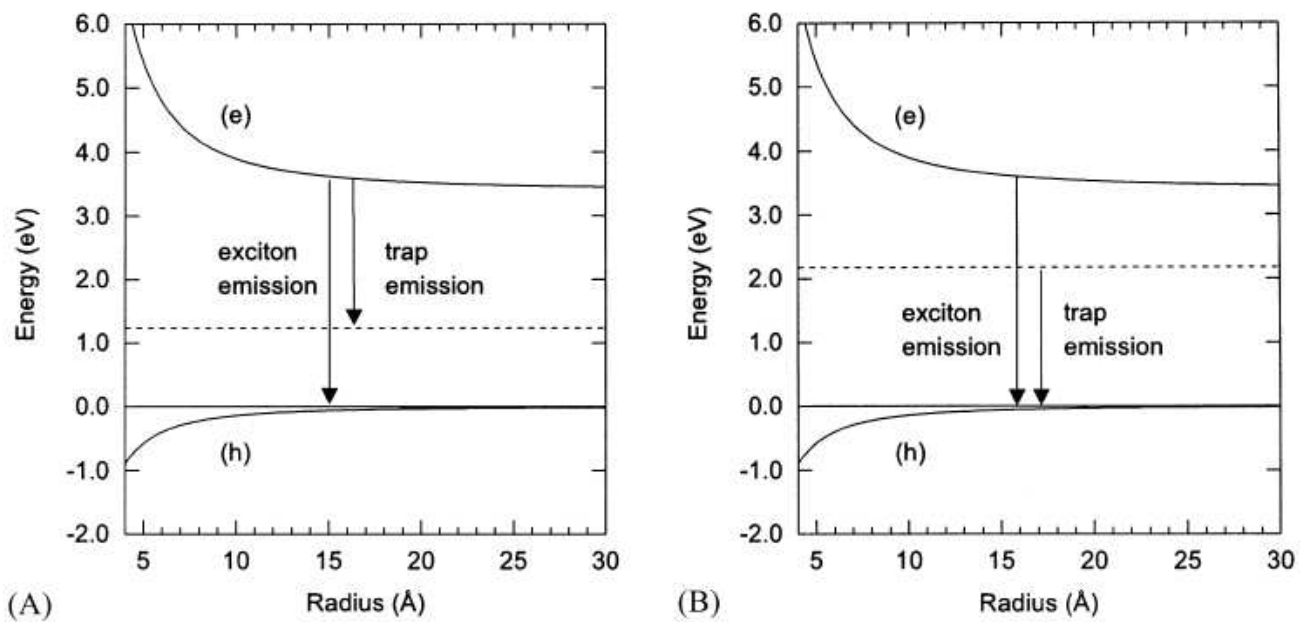

6. ábra. A tiltott sáv szélességének függése a részecskemérettől feltüntetve a lehetséges relaxációs utakat: (A) relaxáció lyuk csapdahelyen, illetve (B) elektron csapdahelyen keresztül [50]. (exciton emission: exciton emisszió, trap emission: csapdahelyekhez köthető emiszió)

A ZnO részecskék alkalmazása során számos esetben elengedhetetlen a részecskék felületének borítása, esetleg szennyező komponensek adagolása bizonyos tulajdonságaik módosítására. Ezek a kompononsek mind befolyásolhatják az emissziós spektrumot.

A részecskék felületmódosítását követően vizsgálták a $\mathrm{ZnO}$ részecskék emissziós tulajdonságait Liu és munkatársai [64], akik Spanhel módszerével előállított ZnO részecskék felületét 3-glicidiloxipropil-trimetoxiszilánnal borították majd szilika-titánia szol-gél vékony rétegbe építették be. A kapott hibrid, fluoreszcens filmnek számos előnyös 
tulajdonságát mutatták meg, mint a hosszútávú stabilitás, a nagyfokú fényáteresztő képesség és a rendkívül sima felület.

Guo és munkatársai [26, 65, 66 ] PVP-t használtak a ZnO részecskék méretnövekedésének megakadályozására. Részletesen vizsgálták a különböző arányban PVP-vel borított $\mathrm{ZnO}$ részecskék fluoreszcencia emissziós tulajdonságait. Azt tapasztalták, hogy a PVP jelentős mértékben megnövelte az UV emisszió intenzitását, a látható emissziót azonban a felület passziválása miatt kioltotta.

Irimpan és munkatársai [28, 29, 67 ] PEI-vel és PVP-vel stabilizált ZnO részecskéket állítottak elő Spanhel [20] módszerével és méretfüggő, valamint gerjesztési hullámhossztól függő emissziót vizsgáltak. Azt tapasztalták, hogy a részecskeméret növekedésével a 390 nm-es és 530 nm-es csúcsok mellett 420 nm-nél és 490 nm-nél is megjelenik egy-egy emissziós csúcs. Kimutatták, hogy a gerjesztő fény hullámhosszának változtatásával $(230 \rightarrow 350 \mathrm{~nm})$ közel 100 nm-rel eltolódik az emissziós csúcs (346 nm $\rightarrow 434 \mathrm{~nm}$ ), a jelenséget szolvatációs és energiaátviteli folyamatokkal magyarázták.

\section{II.3.2ZnO részecskék és filmek kölcsönhatása nemesfémekkel}

\section{Felületi plazmonokkal kapcsolatos alapvetö ismeretek}

A nemesfém nanostruktúrákhoz kapcsolódó kutatások régóta nagy figyelmet kapnak a változatos és komplex optikai tulajdonságaik miatt. Remek példája annak, hogy első látásra kevésbé érdekesnek tűnő anyagokkal (mint a fémek) különböző sajátságokat, illetve gyakran váratlan jelenségeket lehet felfedezni, ha az anyag a fény hullámhosszánál jóval kisebb méretü diszkontinuitásokat tartalmaz.

A nemesfém nanostruktúrákkal kapcsoltban két fő részre különíthető el a plazmonika: a folytonos filmekhez kapcsolható felületi plazmon polaritonok, és a nanorészecskékhez köthető lokalizált felületi plazmonok. Habár a két terület elméletileg világosan elkülöníthető, a különböző jelenségek helyes megítélése a két terület szoros összefonódása miatt nem mindig egyszerü [68].

A nemesfém nanorészecskék különleges méret, alak, összetétel és kémiai környezettől függő tulajdonságainak oka a fénnyel való egyedülálló kölcsönhatásuk [69, 70, 71]. Az optikai viselkedésük magyarázata, annak kvantitatív leírása Gustav Mie-től származik 1908-ból, amikor a Maxwell egyenletek megoldását adta meg homogén gömb 
esetére [72]. A nemesfém nanorészcskék esetén megfigyelhetö lokalizált felületi plazmon tulajdonképpen a fém-dielektrikum határfelületen lévő kollektív elektron oszcilláció (7. ábra a.), amelyet a megfelelö energiájú fénnyel gerjesztve létrejön a felületi plazmon rezonancia, amelynek eredményeképpen erős plazmon abszorpciót, erőteljes fényszórást és megnövekedett lokális elektromos eröteret figyeltek meg [73].

a)

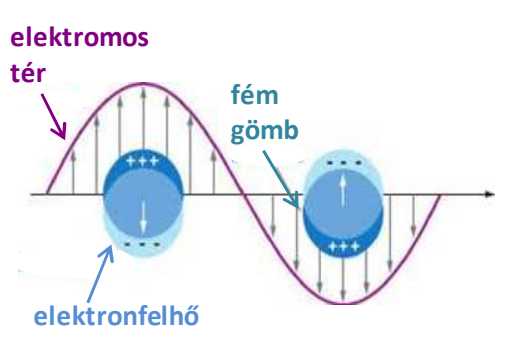

b)

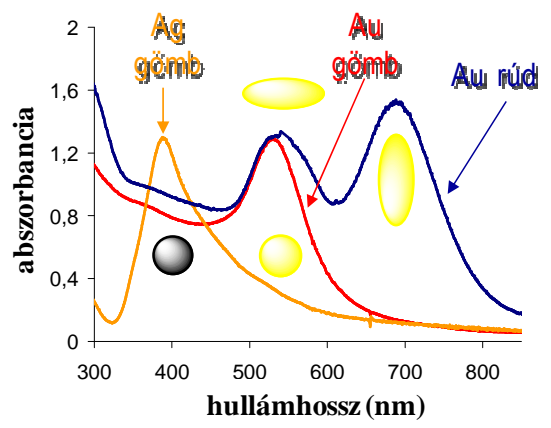

7. ábra. a) A nemesfém nanorészecskék plazmon oszcillációja, b) rezonancia esetén megfigyelt plazmon elnyelés függése a részecskék minőségétől és alakjától [74].

A plazmon rezononcia energiája rendkívül érzékeny a részecskék anyagi minőségére, alakjára, méretére és kémiai környezetére, a plazmon abszorpció helye, valamint az elnyelési csúcsok száma UV-látható spektrumokon nagymértékben függ az említett paraméterektől (7. ábra b.) [75, 76].

A sík fém-dielektrikum határfelületen is megfigyelhető a felületi plazmon rezonancia, az elektromágneses tér csatolódása során létrejövő felületi plazmon polaritonok tulajdonképpen elektronsürüség hullámként foghatók fel, amelyek a határfelület síkjában, a határfelületbe kényszerítve terjednek [68, 77]. Ez a terjedő hullám, lényegében egy evanszcens hullám, egy erős elektromos erőteret hoz létre a határfelület kis környezetében, amely a határfelülettől haladva exponenciális lecsengést mutat (8. ábra). Ez az elektromos erőtér a nanorészecskék körül kialakuló erőtérhez hasonlóan rendkívül érzékeny a benne létrejövő törésmutató változására, ennek kihasználására épül a felületi plazmon rezonancia spektroszkópia (SPR) módszere. 


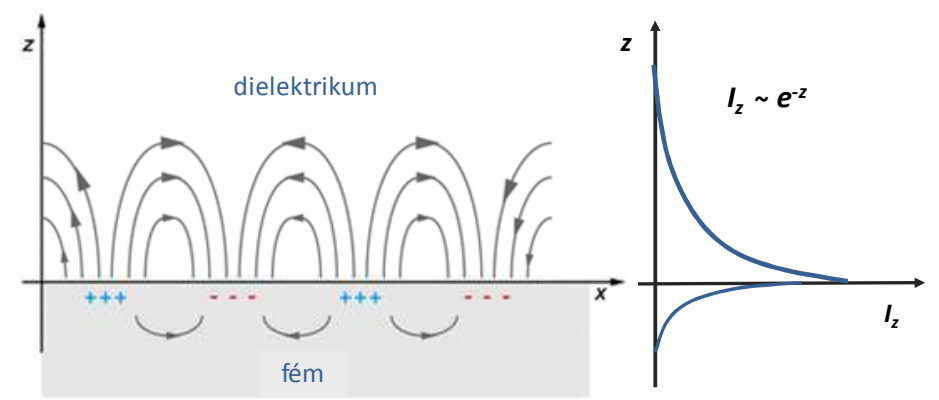

8. ábra. A fém-dielektrikum határfelületben létrejövő elektronsürüség hullámok reprezentációja és az evaneszcens tér lecsengése.

Lényegében ezek azok a tulajdonságok, amelyek folyamatos és intenzív kutatásokra sarkallják a kutatókat, ugyanis a felületi plazmon rezonancia nagyon változatos módokon és módszerekkel alkalmazható a nanoléptékű optikában és a fotonikában. A kémiai környezetre való nagy érzékenység olyan szenzorok kifejlesztését teszik lehetővé, amelyekkel akár nanomólos koncentrációban is kimutathatók bizonyos anyagok [78, 79]. Mindemellett fontos megemlíteni a folyamatosan bővülö orvosbiológiai alkalmazásokat is: a diagnosztika és a terápia területén is számos újdonságot hoztak [80, 81].

\section{ZnO részecskék és filmek viselkedése plazmonikus kölcsönhatásokban}

A nemesfémek floureszcencia emisszióra gyakorolt hatását már az 1970-es években felismerték. Azóta számos kutató foglalkozik nemesfém nanostruktúrák és különböző molekulák, fluoreszcens nanorészecskék és filmek kölcsönhatásának vizsgálatával, amelynek következtében számos jelenség megfigyelhető, úgymint a kioltás, erősítés, hullámhossz eltolódás, új emissziós csúcsok megjelenése, stb.

A plazmonika fejlődésével egyre több dolgozat születik a $\mathrm{ZnO}$ és nemesfém nanorészecskék, nanofilmek plazmonikus kölcsönhatásának jellemzésére. Ezen kísérletek egyik célja a $\mathrm{ZnO}$ fotokatalitikus hatékonyságának növelése [82, 83] vagy a fluoreszcencia emisszió erősítése, amelyet azután sikeresen alkalmazhatnak szenzorok fejlesztésénél, fénykibocsátó diódák hatékonyságának növelésénél $[84,85,86]$. Az elmúlt néhány évben számos dolgozat került publikálásra a ZnO-ot és Au-at tartalmazó nanostruktúrák előállításáról és fluoreszcencia vagy fotokatalitikus tulajdnonságaik jellemzéséről, ennek ellenére kevés olyan munka született, amelyben a kölcsönhatás mechanizmusának felderítését célozták meg. 
Több szerző is vizsgálta $\mathrm{ZnO}$ rudak felszínére kapcsolt arany, illetve ezüst részecskék hatását az emisszióra $[87,88,89,90,91]$. Az eredményeik viszonylag jó egyezést mutatnak: az UV emisszió erősödését és a látható emisszió csökkenését vagy teljes kioltását tapasztalták. A folyamat mechanizmusának a töltésátvitelt valószínűsítik (9. ábra): a nemesfém és a $\mathrm{ZnO}$ Fermi szintje közel esik egymáshoz, kapcsolás esetén létrejöhet a Fermi szintek kiegyenlítődése, amely révén töltésátvitel valósulhat meg a ZnO-tól a fém felé. Ezek az elektronok a fémben magasabb energiaszintre jutva újabb átvitellel a ZnO vezetési sávjába jutnak vissza, ahonnan UV vagy látható fény kibocsátása közben visszakerülnek az alapállapotba. Mivel a gerjesztett állapotú töltéshordozók direkt rekombinációja mellett nem mehet végbe a fenti folyamat, ezért összességében az UV emisszió aránya nőni, a láthatóé pedig csökkenni fog.
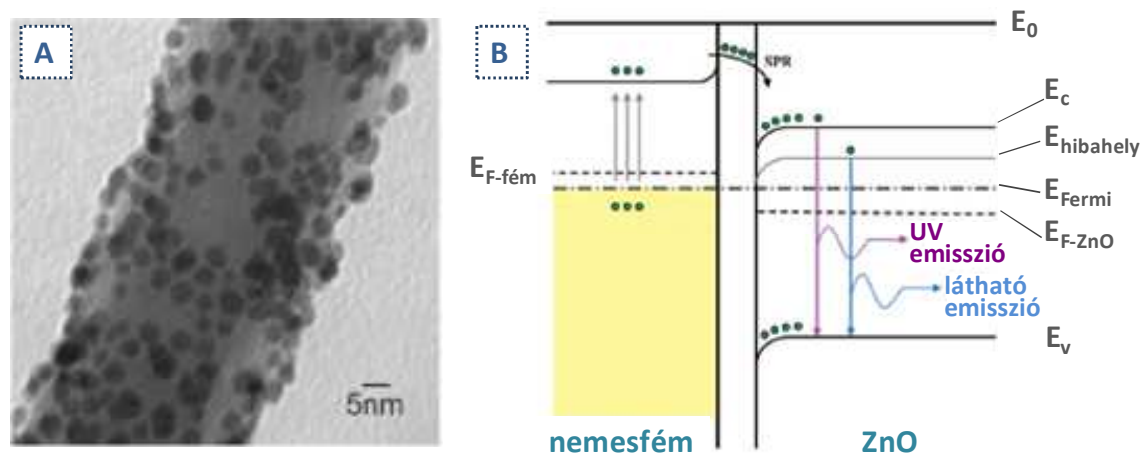

9. ábra. a) ZnO rúd felszínére kapcsolt Au nanorészecskék SEM felvétele [89], b) a ZnO-Au kompozitok esetén létrejövő plazmonikus kölcsönhatás fluoreszcencia emisszióra gyakorolt hatásának javasolt mechanizmusa [92].

Subramanian és munkatársai [93] részletesen tanulmányozták $\mathrm{ZnO}$ részecskék fluoreszcencia emissziós tulajdonságait etanolos közegű szoljaikban: töltésviszonyokat tanulmányoztak fém jelenlétében, illetve nélküle. Eredményeik azt mutatták, hogy a vezetési sávban felhalmozódó elektronok a látható emisszió kioltását okozzák, azonban kimutatták, hogy az elektronfelesleg oldott oxigén segítségével eltávolítható. A platinával és és arannyal borított $\mathrm{ZnO}$ részecskék eltérő viselkedést mutattak: a platina esetében megfigyelt ohmos kölcsönhatás elősegíti a töltésmentesítést az oldat felé, míg az arannyal borított $\mathrm{ZnO}$ esetén az elektronok megoszlanak a fém és a félvezető között, amelynek eredménye a Fermi-szintek kiegyenlítődése és az UV emisszió kioltása.

Arannyal borított $\mathrm{ZnO}$ filmeket állítottak elő Li és munkatársai [94]. Fluoreszcencia emissziós mérések az UV emisszió jelentős erősítését és a látható emisszió teljes kioltását mutatták ki, amelyet a fém és a félvezető közti direkt töltéstranszferrel magyaráztak. A 
fém/félvezető határfelületen létrejövő lokalizált felületi plazmonok rezonanciájának következtében kialakuló kölcsönhatás lehetővé teszi az elektronoknak a csapdahelyekröl a vezetési sávba való átjutását elősegítve az UV emissziót.

Haglund, Lawrie és Mu [95, 96] részletesen vizsgálták Ag és Au filmek hatását egy 70 nm-es ZnO film emissziós sajátságaira, a kettő közti távolság szabályozására különböző vastagságú $\mathrm{MgO}$ távtartó réteget építettek be. Eredményeik az UV és a látható emisszió erősödését mutatták, a jelenségeket a fém film szerkezetének (részecskés vagy kvázifolytonos) és az emisszió típusának függvényében értelmezték. A látható emisszió esetén a részecskés és a kvázifolytonos filmekkel való kölcsönhatást is a lokalizált felületi plazmonok dipól-dipól szórásával magyarázták. Az UV emisszió esetében bonyolultabb a magyarázat: a részecskés filmek esetén a lokalizált felületi plazmonok hatását és a gerjesztett elektronok alagutazását feltételezik, míg a kvázifolytonos filmeknél a felületi plazmon polaritonok hatására bekövetkező Purcell-erösítést említik meg.

Régóta ismert, hogy a $\mathrm{ZnO}$ jelentős fotokatalitikus aktivitást mutat, újabb kutatások során az $\mathrm{Au}-\mathrm{ZnO}$ kompozitok fluoreszcenciás vizsgálata mellett nagy érdeklődésre tart számot ezeknek az új anyagoknak a katalitikus teljesítményének jellemzése. Több tanulmányban is beszámolnak $\mathrm{Au}-\mathrm{ZnO}$ kompozit anyagok fotokatalitikus hatásáról összevetve az azonos módon, Au hozzáadása nélkül készült katalizátorokkal és szerencsére található néhány példa párhuzamosan végzett fluoreszcencia emissziós mérésekre is [82, 83, 97, 98 ]. Ezeket az eredményeket áttekintve azt tapasztaljuk, hogy a nemesfém segítségével növelhető a katalizátor aktivitása, azonban a jobb katalizátorok gyengébb emissziót mutatnak és fordítva.

\section{II.4 Nanorészecskék önszerveződése, rendezett struktúrák létrehozása}

A nanotechnológia egyik nagy kihívása a nanorészecskék rendezett vagy akár hierarchikus struktúrákba történő szervezése. A megfelelő rendezettség elérésével olyan új elektromos, optikai, mechanikai vagy mágneses tulajdonságai jelenhetnek meg az anyagnak, amely számos alkalmazás szempontjából lehet kiemelkedően fontos. Kiváló példa erre a fotonikus kristály, amely az anyag nanoléptékü periodicitásának köszönhetően mutat speciális optikai tulajdonságokat (ún. fotonikus tiltott sáv). 
A szabályos struktúrák létrehozásának jelentős igénye magával vonta a számos különböző eljárás kifejlesztését, amelyekkel különböző elven és megvalósításban lehet irányítani a részecskék önszerveződését $[99,100,101]$. A kolloid méretü egységekből történő építkezés nagy előnye, hogy a paraméterek megfelelő optimálása mellett az eljárások jelentős része viszonylag olcsó, gyors és az esetek többségében jól kontrollálható. A rendezett struktúrák létrehozásának követelménye, hogy az azt felépítő egységek is szabályosak legyenek mind alak, mind méret szempontjából [102].

A részecskék önszerveződése kivitelezhető egyszerü ülepítéssel, kapilláris erők vagy külső tér által irányítva, adszorpciós vagy más biospecifikus kölcsönhatások által vezérelve, de sikeresen alkalmaznak különböző templátokat is [103]. A rendezett egységekbe tömörült kolloid rendszerek között megkülönböztethetünk 3, 2 illetve 1 dimenziós szervezett struktúrákat (10. ábra).
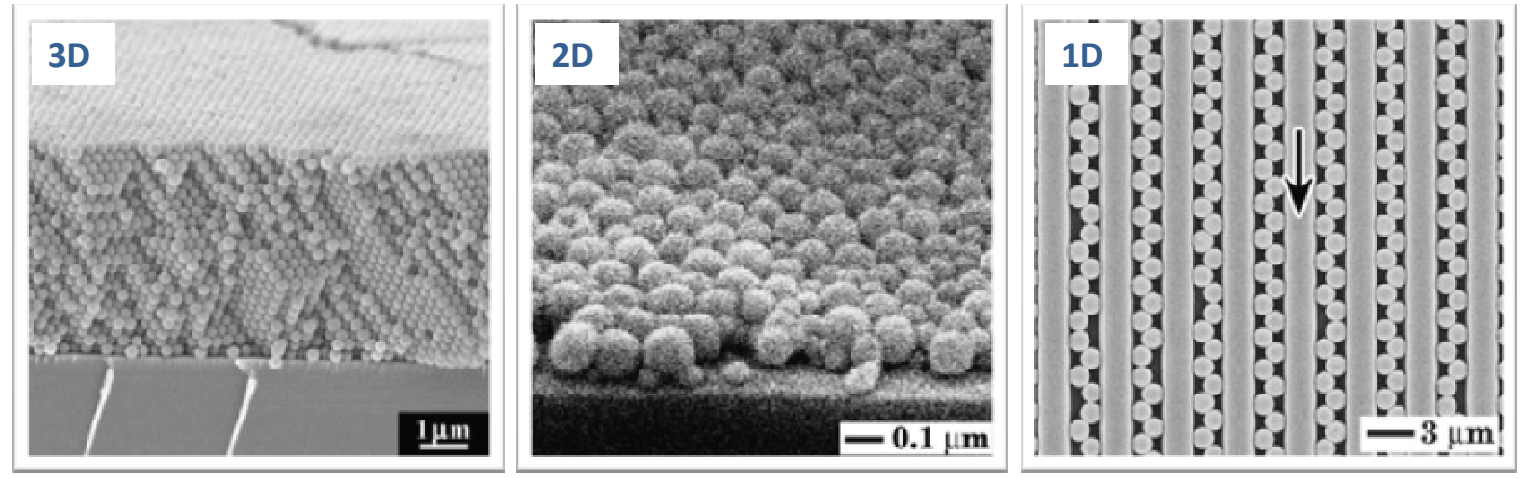

10. ábra. Részecskék önrendeződésével létrehozott 3D [104], 2D [105] és 1D [106] rendszerek.

A háromdimenziós rendszereket a monodiszperz egységek egyszerü ülepítésével elő lehet állítani [40]. Az ülepítéses folyamat felgyorsítására alkalmaznak centrifugálást, elektroforézist, szürést és egyéb módszereket [103], illetve a kétdimenziós technikák közül is van olyan, amelyekkel 3D struktúrák hozhatók létre.

A nanorészecskék kétdimenzióban történő rendezésére használatos módszerek három alapvető elv valamelyikének különböző formában történő megvalósítása (11. ábra). Folyadék/levegő határfelületbe juttatott részecskék (11. ábra A) megfelelö felületi tulajdonságaik esetén tökéletesen rendezett, úgynevezett szoros hexagonális illeszkedésbe tömöríthetők. Ezt az elvet általában Langmuir-mérlegben alkalmazzák. A vízfelszínen létrehozott rendezett film többféle technikával is átvihető különböző szilárd hordozókra: a Langmuir-Blodgett [107, 108] és a Langmuir-Schäfer [109] technikák a legelterjedtebbek, de létezik más módszer is (Roll-to-Roll [109], stb.). 

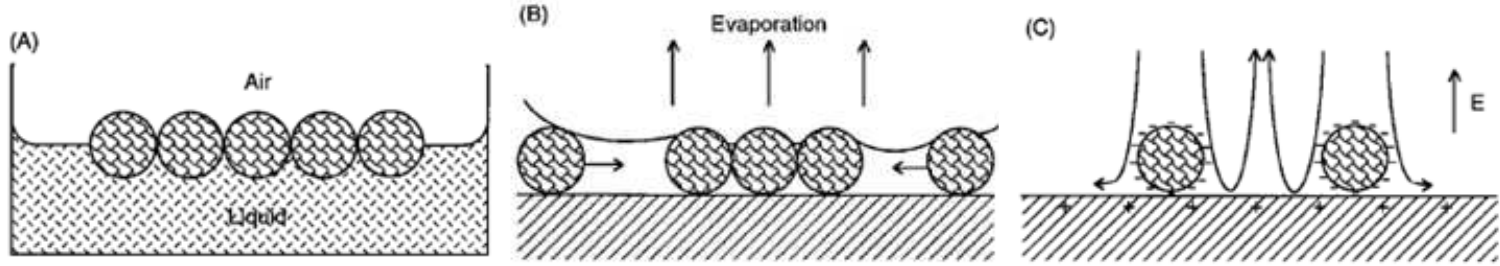

11. ábra. Gömb alakú részecskék hexagonálisan rendezett struktúráinak előállítása [102].

A részecskék diszperziós közegének párolgása (11. ábra B) közben létrejövő mozgó folyadékmeniszkusz mentén ható kapilláris erőket is ki lehet használni a részecskék önrendezésénél. A párolgás következtében elvékonyodó folyadékmeniszkusz közelében a részecskékre vonzó kapilláris erők hatnak, amelyek a folyadékcsepp széléhez juttatják öket. Ez az elv számos kísérleti elrendezésben megvalósítható: a hordozóra cseppentett megfelelő koncentrációjú diszperzió közegének kontrollált elpárologtatása [ 110 ], a részecskéket tartalmazó diszperzióba vertikálisan bemerített hordozó lassú kihúzása illetve a diszperzió közeg elpárologtatása [111], a konvektív önrendeződés [112] (itt egy mozgó tárgylemez szabályozza a folyadékmeniszkusz mozgását), továbbá alkalmazható a forgatásos filmképzés (spin coating) [113] is. A párologtatás paramétereinek illetve a részecskék koncentrációjának változtatásával széles tartományban szabályozható vastagságú filmeket lehet előállítani [114], ezzel a módszerrel 3D kolloid kristályok is előállíthatók.

Külső elektromos erötér hatására (11. ábra C) is bekövetkezhet a részecskék önrendeződése. Elektroforetikus filmképzés során a részecskék két elektróda közti elektromos térben haladnak, megfelelően nagy erőtér mellett a hordozóra tapadt részecskék képesek elmozdulni és tömör, hexagonális illeszkedésű filmet létrehozni [102].

Egydimenziós struktúrák létrehozásakor általában külső elektromos vagy mágneses tér irányítja a részecskék mozgását, illetve egy másik lehetőség a különböző templátok alkalmazása [103].

A fentebb részletezett módokon, önszerveződéssel előállítható rendezett struktúrákhoz a szabályos, monodiszperz építőkövek gömb alakúak, ugyanis alakjuk miatt ezekkel a legegyszerübb a megvalósítás. Ennek ellenére anizometrikus részecskékkel is végeznek kísérleteket, rúd alakú részecskék Langmuir-Blodgett-filmjeit vizsgálták Kim és munkatársai [115].

A monodiszperz gömbök kémiai minőségét illetően messze legtöbbet alkalmazott anyagok a Stöber [116] módszerével előállított szilika, valamint a polisztirol részecskék 
[117]. Ezek a részecskék további felületmódosítás nélkül is kiváló tulajdonságokkal bírnak az önszerveződés szempontjából: viszonylag könnyedén létrehozhatók gyakorlatilag tökéletes struktúráik. A részecskék méretének hatását is meg kell említenem: azonos felületi tulajdonság esetén a méret növekedésével általában egyre könnyebbé válik az önszerveződés.

\section{II.4.1 A Langmuir-Blodgett technika}

Irving Langmuir és Katharine Blodgett az 1920-as és 1930-as években úttörö munkát végeztek határfelületi monomolekulás filmek vizsgálatában [118]. A víz/levegő határfelületbe juttatott különböző amfifil jellegü molekulák határfelületi viselkedésének leírása mellett eljárást dolgoztak ki a filmek szilárd hordozóra történő átvitelére is [119]. Az azóta Langmuir-Blodgett (LB) technikának elnevezett eljárást számos anyagra alkalmazták már, amfipatikus (poláris és apoláris részeket is tartalmazó) molekulák mellett különböző nanorészecskékkel is jó eredményeket értek el [120,121]. Az LB technika lényege, hogy a Langmuir mérlegben víz/levegő határfelületen kialakított, tömör, monorétegű filmet szilárd hordozóra visszük át (12. ábra). Az eljárás ismétlésével többrétegű filmeket állíthatunk elő egyidejüleg a hordozó mindkét oldalán. Amennyiben az egyedi nanorészecskék alakja, illetve felületi tulajdonsága megfelelő, akkor tökéletesen rendezett szerkezetü filmek előállítására is lehetőség nyílik.

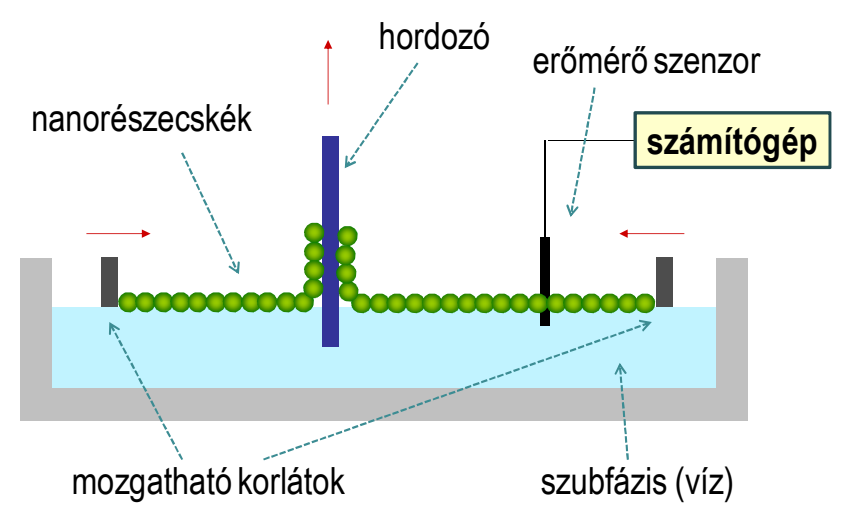

12. ábra. A Langmuir-Blodgett technika.

A határfelületi folyamatok követése a határfelületben ható erő mérésén keresztül a felületi feszültség, illetve az oldalnyomás segítségével valósul meg [121]. A felületi feszültség a határfelületben fellépő, az új felület létrehozása ellen ható összetartó erő, az oldalnyomás $(\pi)$ pedig a filmmel borított folyadékfelszín esetén mérhető felületi feszültség 
$\left(\gamma_{v}\right)$, valamint a tiszta folyadék felületi feszültségének $(\gamma)$ különbségeként definiálható: $\pi=\gamma_{v}-\gamma$. Az oldalnyomás felfogható a vizsgált molekulák, illetve részecskék által a korlát(ok)ra kifejtett nyomásként, innen egyenes út vezet a háromdimenziós rendszerekkel való analógiához. A vízfelszíni film oldalnyomását a molekulák rendelkezésére álló terület függvényében mérve megkaphatjuk a kétdimenziós állapotgörbét. A felület csökkentésével az oldalnyomás nő: a film ideális gáz analógja, majd kondenzációs szakasz következik. Tovább csökkentve a vízfelszín területét a kondenzált fázisnak megfelelő szakasz mérhető, ennél nagyobb nyomásnál a film összeroppan (kollapszus következik be). Az oldalnyomás vs. terület izoterma alakja az egyes anyagok esetén nagyon változatos: gyakran nem különíthetők el egyértelműen az egyes fázisoknak megfelelő szakaszok.

A kísérlet során elöször a részecskéket (vagy molekulákat) megfelelö oldószerben kell diszpergálni (illetve felodani). A diszperziós közeggel szemben támasztott követelmény, hogy stabil, aggregációtól mentes diszperzót lehessen vele létrehozni, a mérés során használt szubfázissal (általában víz) ne elegyedjen, terítést követően szétterüljön az alsó fázison, illetve hogy illékony legyen. A leggyakrabban használt közegek a kloroform, a diklór-metán, a hexán és a toluol. A részecskéket tartalmazó úgynevezett terítőszolt a vízfelszínre juttatjuk, az oldószer elpárolgását követően tömöríthető a vízfelszíni film. A kompresszió során felvett oldalnyomás vs. terület izotermák kiértékelésével kiszámolhatjuk az egy részecske által elfoglalt terület nagyságát. A vízfelszíni film többszöri kompressziós-dekompressziós izotermái alapján a részecskerészecske kölcsönhatásokra, illetve a részecske-szubfázis kölcsönhatásokra lehet következtetni [122, 123].

ZnO részecskék vízfelszíni Langmuir- és szilárd hordozós Langmuir-Blodgettfilmjeinek előállítására, jellemzésére kevés példa található az irodalomban. Magyarországon Hórvölgyi Zoltán kutatócsoportjában született ezzel kapcsolatosan néhány publikáció $[124,125,126,127]$, én magam is ebben a kutatócsoportban kezdtem el $\mathrm{ZnO}$ nanorészecskékkel és rendezett filmjeikkel foglalkozni. A különböző méretű ZnO és $\mathrm{SiO}_{2}$ részecskék felhasználásával készített többrétegű, változó összetételü bevonatokat optikai (antireflexiós) és fotokatalitikus tulajdonságaik szempontjából vizsgáltuk.

Tudomásom szerint ezen kívül két dolgozatban számoltak be $\mathrm{ZnO}$ részecskék vízfelszíni filmjeinek vizsgálatáról. Shortell és munkatársai [128] dodekántiollal borított $\mathrm{ZnO}$ részecskék vízfelszíni filmjeit állították elő, majd a Langmuir-Blodgett és a 
Langmuir-Schäfer technikákat is alkalmazták a vízfelszíni film szilárd hordozóra történő átviteléhez. Váratlan és érdekes jelenséget figyeltek meg: a TEM gridre elkészített filmeknél rúd alakba rendeződött részecskéket láttak (13. ábra). Ezt azzal magyarázták, hogy a felületmódosító dodekántiol hosszú, rúd alakú micellákat képez és a részecskék a micella belsejében rendeződnek.

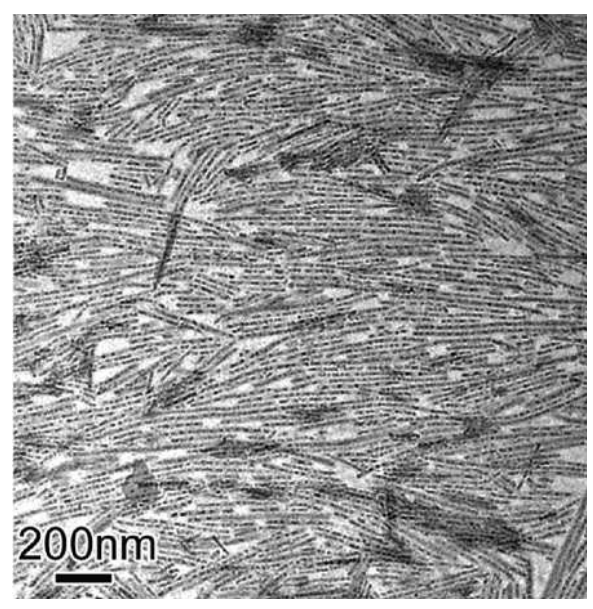

13. ábra. $1 \mathrm{D} \mathrm{ZnO}$ struktúra TEM képe: hosszú, rúd alakú dodekántiol micellákba zárt ZnO részecskék filmje Langmuir-Schäfer technikával [128].

Azam és munkatársai [129] ZnO részecskék Langmuir-Blodgett-filmjeit állították elő ITO-s (indium-ón vegyes oxid) hordozókon és ciklikus voltammetriás méréseket végeztek a film szenzorikus tesztelésére. Különböző $\mathrm{pH}$-jú foszfát puffer oldatokra eltérö jeleket mértek, amelyből arra következtettek, hogy az általuk előállított elektróda gázszenzorként alkalmazható.

\section{II.4.2 Mintázott felületek}

A nanorészeckék önszerveződő struktúrákba rendezése során egyre gyakrabban láthatunk példát arra, hogy a részecskék mozgását valamilyen templát irányítja. A különböző felületi struktúrájú templát lehetőséget ad szubmikrométeres periodicitásokat tartalmazó, mintázott felületek létrehozására kolloidkémiai módszerekkel. Elterjedten használnak templátként PDMS-t (polidimetil-sziloxán), amely egy rugalmas, gumiszerü anyag. A PDMS felszín strukturálásának lényege, hogy a különböző irányokban megnyújtott gumit oxidálják, ennek hatására egy merev réteg alakul ki felszínén, amely relaxálás után periodikus mintázatokat formáz. Az alkalmazott megnyújtás irányától és erősségétől függően különböző felületeket kaphatunk (14. ábra) [130, 131]. 
Hullámos felszínü (párhuzamos hullámok) PDMS templát létrehozásának és alkalmazásának különböző részecskék mintázatainak kialakításában részletes munkát végeztek Andreas Fery kutatócsoportjában [132]. Megállapították, hogy a létrejövő hullámok hullámhossza az alkalmazott oxigén plazma kezelés idejével (lényegében a felső, oxidált réteg vastagságától), az amplitúdója pedig az alkalmazott feszültség nagyságától (megnyújtás) függ.

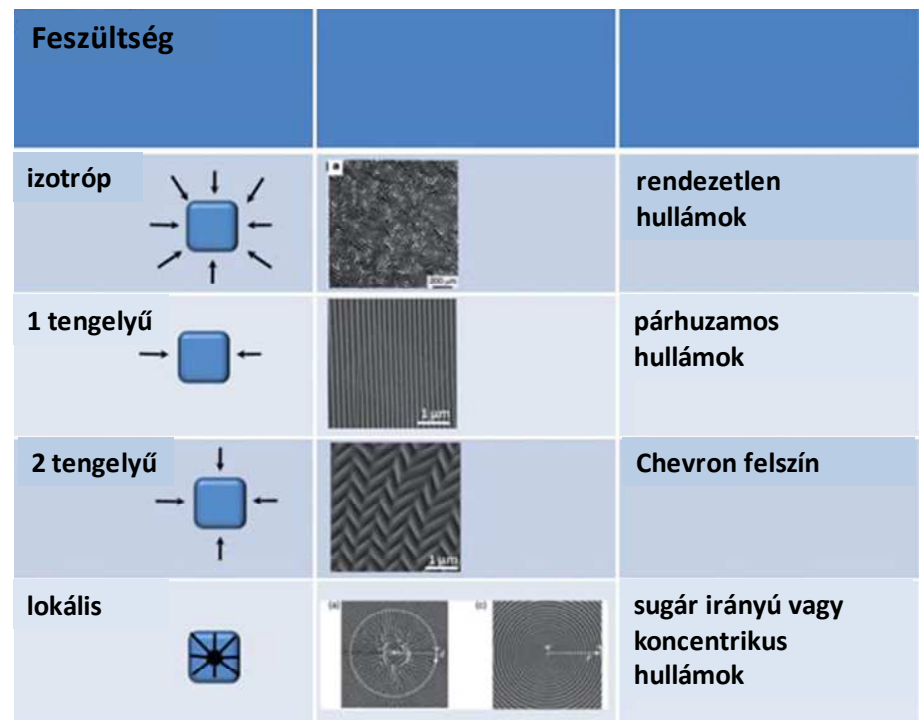

14. ábra. PDMS gumi felszínén különböző feszültség terek alkalmazásával létrehozható mintázatok [131].

A strukturált felszínü bélyegző alkalmazható részecskék mintázatokba rendezésén kívül az úgynevezett mikrokontakt nyomtatás eljáráshoz is [132]. Ennek az eljárásnak az elve rendkívül egyszerü, talán éppen az adja a szépségét. A kezelt felületű bélyegző felszínére különböző molekulákat (általában tiolokat vagy polielektrolitokat) adszorbeáltatnak, majd ezt egy megfelelően előkezelt szubsztrátra nyomva az adszorbeált molekulák csak arról a részről fognak áttapadni a hordozóra, ahol közvetlenül érintkeztek vele (15. ábra).

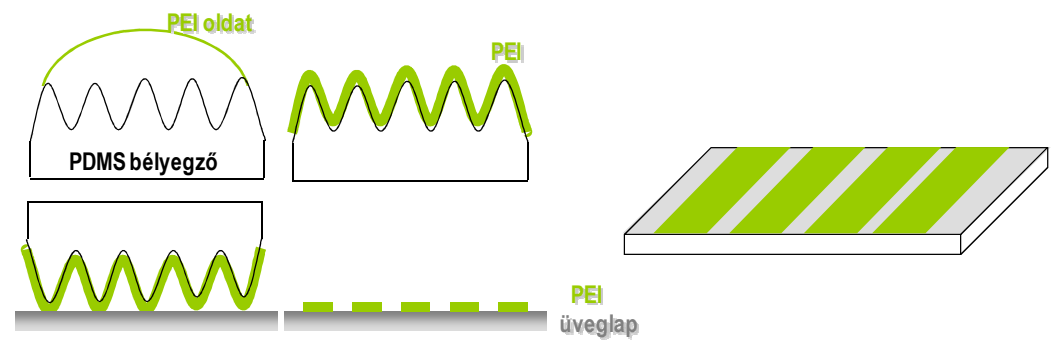

15. ábra. A mikrokontakt nyomtatás folyamata. 
A sávos felszínü PDMS bélyegzők nanorészecskék mintázatainak kialakításához való felhasználása viszonylag új eljárásnak számít, azonban egyszerü és olcsó kivitelezhetősége miatt az alkalmazások szempontjából nagyon előnyös. A részecskék rendezése a hordozó és a bélyegző közötti bezárt térben kapilláris erők irányításával történik (16. ábra) [133, 134]. A módszert többek között alkalmazták arany nanorészecskék sávos mintázatokba történő rendezésére, így olyan plazmonikus felületeket hoztak létre, amelyek a felület által érzékenyített Raman-szórás technikánál használhatók előnyösen $[131,135]$.

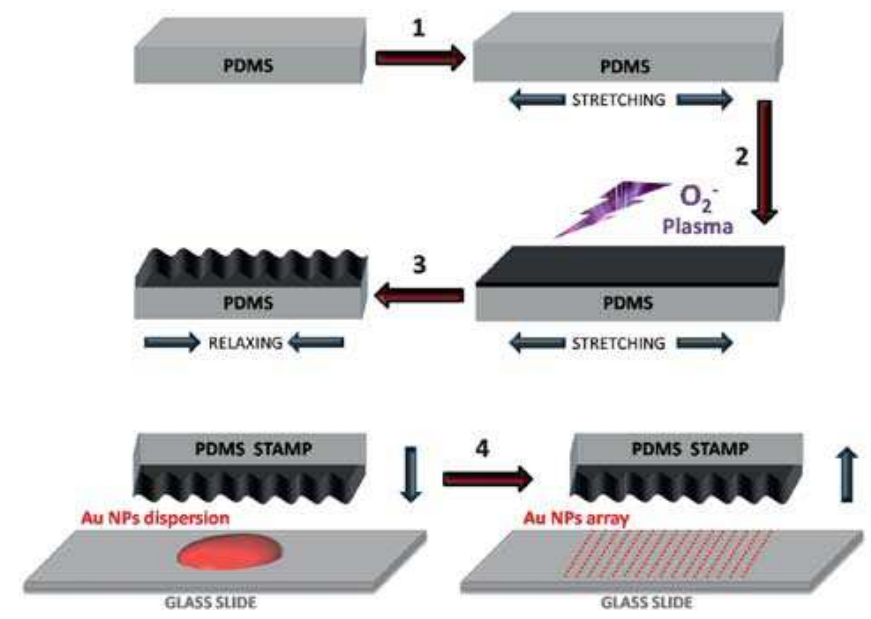

16. ábra. A hullámosított felszínű bélyegző létrehozása és alkalmazása a nanorészcskék önszerveződő módon mintázatokba rendezéséhez [135]. 


\section{CÉLKITÜZÉSEK}

A $\mathrm{ZnO}$ nanorészecskék szintézisének és vizsgálatának kiterjedt irodalma van köszönhetően a széleskörü alkalmazási lehetőségeinek. Található példa olyan eljárásokra, amelyekkel közel monodiszperz, gömb alakú részecskék nyerhetők. Kevés olyan dolgozat született azonban, amelyben szabályos részecskékből önszerveződéses technika segítségével létrehozott rendezett struktúrákról számolnának be. Doktori munkám során rendezett nanorészecskés filmek létrehozását tüztem ki célul, amelyeket potenciális alkalmazási lehetőségeik szempontjából kívántam jellemezni. Ezek figyelembe vételével a kísérleti munkámat az alább megfogalmazott célok megvalósítása köré építettem fel.

- Meulenkamp módszerét választottam 3-7 nm-es mérettartományba eső közel monodiszperz $\mathrm{ZnO}$ nanorészecskék szintéziséhez. A részecskék fluoreszcens elven müködő szenzorként való alkalmazhatóságának érdekében célom volt részletesen tanulmányozni az emissziós sajátságaikat etanolos közegü szoljaikban, kvarc, illetve arannyal bevont üveg hordozóra felvitt Langmuir-Blodgett-filmjeiken. Célom volt, hogy a különböző felépítésű $\mathrm{Au}-\mathrm{ZnO}$ hibrid filmek fluoreszcencia emissziós vizsgálatával elemezzem a fém és a félvezető között létrejövő plazmonikus kölcsönhatást, illetve felderítsem, hogy milyen paraméterek mellett érhető el legnagyobb erősítés, amelyet azután a szenzorfejlesztés során lehet hasznosítani.

- Autoklávban 200-500 nm mérettartományba eső monodiszperz, gömb alakú ZnO részecskéket preparáltam dietilén-glikolos közegben. A részecskék alapos szerkezetvizsgálatával célom volt a szilárd hordozós filmjeik optikai modellezéséhez szükséges paraméterek meghatározása. A részecskékből szoros illeszkedésü, hexagonálisan rendezett filmeket hoztam létre a Langmuir-Blodgett technika segítségével kvarc hordozón, amelyeket azután optikai és fluoreszcenciás tulajdonságaik szempontjából jellemeztem. Kiemelt figyelmet fordítottam a reflektancia spektrumaik kiértékelésére: célom volt a tanszékünkön korábban kidolgozott optikai modell továbbfejlesztése. A szabályos felépítésből adódóan lehetőség van a film szerkezetét pontosabban leíró modell kidolgozására, amellyel jobb közelítés adható a film effektív törésmutatójára és vastagságára, továbbá a speciális modellnek köszönhetően becsülhetö a filmben a részecskék egymástól mért átlagos távolsága is. 
- A 200-500 nm mérettartományban előállított részecskék felhasználásával templát által irányított önrendeződéses elven mintázott felületek előállítását tüztem ki célul kvarc- és arannyal bevont üveghordozókon. Ehhez a részecskék, a hordozó és a hullámosított felszínủ templát felületi tulajdonságainak egyidejü optimalizálását kellett megvalósítani. A megfelelően rendezett mintázatok létrehozását követően UV-látható transzmittancia és fluoreszcencia emissziós vizsgálatokat végeztem. 


\section{KÍSÉRLETI RÉSZ}

\section{IV.1 ZnO és Au részecskék szintézise}

\section{IV.1.1 ZnO részecskék előállítása a 3-7 nm mérettartományban}

A szolokat egy Meulenkamp által kidolgozott eljárás [21] szerint állítottam elő. Ezzel a módszerrel 3-7 nm átlagos átmérőjü, izometrikus $\mathrm{ZnO}$ részecskéket tartalmazó etanolos közegű szolt nyertem. A nagyjából $3 \mathrm{~nm}$ átmérőjü részecskék mérete a szintézist követően lassan tovább növekszik, bizonyos idő után azonban elér egy maximális értéket (kb. $7 \mathrm{~nm}$ ). A dolgozat további részében az adott méretü $\mathrm{ZnO}$ részecskék elnevezést fogom használni, de ez természtesen minden esetben átlagos átmérő értékre vonatkozik.

Az eljárás során $1,10 \mathrm{~g} \mathrm{Zn}(\mathrm{AcO})_{2} \cdot 2 \mathrm{H}_{2} \mathrm{O}$-ot (>98,0\%, purum, Fluka) $50 \mathrm{ml}$ abszolút etanolban (> 99,99\%, a.r., Molar Chemicals) forralás és keverés közben feloldottam, majd az oldatot hirtelen lehütve vízmentes $\mathrm{Zn}(\mathrm{AcO})_{2}$ vált ki. Eközben 0,29 g $\mathrm{LiOH}_{2} \mathrm{H}_{2} \mathrm{O}-\mathrm{t}$ (>99\% SigmaUltra, Sigma) $50 \mathrm{ml}$ abszolút etanolban szobahőmérsékleten ultrahangfürdőben feloldottam. A LiOH oldatát csepegtető tölcsér segítségével kb. egy óra alatt hozzáadagoltam a $\mathrm{Zn}(\mathrm{AcO})_{2}$ oldatához, miközben az elegy hőmérséklete végig $0^{\circ} \mathrm{C}$ körül volt. Néhány órás kevertetés után a kész szolt két részre osztottam: az egyik részletet szobahőmérsékleten $\left(\sim 22^{\circ} \mathrm{C}\right)$, a másik részletet hütőszekrényben $\left(\sim 5^{\circ} \mathrm{C}\right)$ tároltam. $\mathrm{A}$ szol szárazanyag tartalma $0,4 \mathrm{~g} / 100 \mathrm{ml}$.

\section{Porminta elöállitása}

A Meulenkamp módszerével előállított $\mathrm{ZnO}$ részecskék röntgendiffrakciós vizsgálatához pormintát készítettem. Ehhez az etanolos közegủ szolhoz destabilizáló szert, heptánt (>99,9\%, Molar Chemicals) adtam kétszeres mennyiségben. Ennek hatására a részecskék aggregálódtak, majd centrifugálást (Hettich Universal 30F, 2000 fordulat/perc, 5 perc) követően kiülepedtek. A felülúszó eltávolítása után a részecskéket etanolban újradiszpergáltam az eredeti koncentráció kétszeresére. Háromszoros mennyiségü heptán hozzáadása, újbóli centrifugálás és a felülúszó eltávolítása után az üledéket szárítószekrényben $80^{\circ} \mathrm{C}$-on 2 óra alatt beszárítottam. 


\section{IV.1.2 Polietiléniminnel (PEI) stabilizált ZnO részecskék előállítása}

A 3 nm-es részecskék a szintézist követően tovább növekednek, a szolok stabilizálása érdekében polietiléniminnel borítottam a $\mathrm{ZnO}$ részecskék felszínét. A negatív felületi töltésű részecskékre elektrosztatikus vonzó kölcsönhatások miatt egyszerüen kapcsolható a pozitív töltésü kationos polielektrolit, a PEI. A ZnO részecskék szintézisét PEI jelenlétében végeztem. Az eljárás során a kiindulási $50 \mathrm{ml}$ etanolhoz (> 99,99\%, a.r., Molar Chemicals) a $\mathrm{Zn}(\mathrm{AcO})_{2} \cdot 2 \mathrm{H}_{2} \mathrm{O}(>98,0 \%$, purum, Fluka) bemérése elött hozzáadtam 0,4 g PEI-t (M.W.: 800, Aldrich), a hozzáadandó mennyiséget itt nem részletezett előkísérletek eredménye alapján választottam. Ezek után a $\mathrm{ZnO}$ részecskék szintézise megegyezett a IV.1.1 pontban leírtakkal.

\section{IV.1.3 ZnO részecskék előállítása a $200-500$ nm mérettartományban}

A szintézist Jezequel módszere [39] alapján autoklávban (Parr 5500 Series) végeztem, mellyel 234, 301, 341, 349 és 457 nm átlagos átméröjü, gömb alakú ZnO részecskéket tartalmazó szolokat kaptam. Az autoklávban végzett preparáció előnye, hogy reprodukálhatóan és pontosan szabályozható a felfütési sebesség és a keverés. A dolgozat további részében az adott részecskék elnevezésében használt méret mindig a transzmissziós elektronmikroszkópos képek alapján meghatározott átlagos átmérőt fogja jelenteni.

Az előállítás során 1,1-2,2g $\mathrm{Zn}(\mathrm{AcO})_{2} \cdot 2 \mathrm{H}_{2} \mathrm{O}-$ ot (>98,0\%, purum, Fluka) és $100 \mathrm{ml}$ dietilén-glikolt (>99,9\%, puriss, Molar Chemicals) bemértem az autoklávba (1. táblázat), egy szelepet levegőre nyitottam (a reakciótérben kialakuló kismértékü túlnyomás elkerülése végett), majd a következő paramétereket állítottam be: $160^{\circ} \mathrm{C}$ hömérséklet, 3,5 $5^{\circ} \mathrm{C}$ perc felfütési sebesség, $400 \mathrm{rpm}$ keverési sebesség. A reakcióelegyet 1 órán át kevertettem a beállított hőmérsékleten, majd lehülést követően a kész szolokat szobahőmérsékleten tároltam.

1. táblázat. A $\mathrm{ZnO}$ részecskék szintézise során használt prekurzor $\left(\mathrm{Zn}(\mathrm{AcO})_{2} \cdot 2 \mathrm{H}_{2} \mathrm{O}\right)$ mennyisége és a kész szolok szárazanyag-tartalma.

\begin{tabular}{lccccc}
\hline $\mathbf{d}_{\text {TEM, }} \mathbf{n m}$ & $\mathbf{2 3 4} \pm \mathbf{1 1}$ & $\mathbf{3 0 1} \pm \mathbf{1 2}$ & $\mathbf{3 4 1} \pm \mathbf{1 5}$ & $\mathbf{3 4 9} \pm \mathbf{1 4}$ & $\mathbf{4 5 7} \pm \mathbf{1 6}$ \\
\hline $\mathbf{m}\left(\mathbf{Z n}(\mathbf{A c O})_{2} \cdot \mathbf{2 H}_{\mathbf{2}} \mathbf{O}\right), \mathbf{g}$ & 1,1 & 2,2 & 1,6 & 2,2 & 1,1 \\
$\mathbf{c}(\mathbf{g} / \mathbf{1 0 0} \mathbf{m l})$ & 0,407 & 0,814 & 0,61 & 0,814 & 0,407 \\
\hline
\end{tabular}




\section{Porminta elöállítása}

$\mathrm{Az}$ autoklávban előállított $\mathrm{ZnO}$ részecskék jellemzéséhez (röntgendiffrakció, $\mathrm{N}_{2}$ adszorpció-deszorpció, kisszögü röntgenszórás) pormintát készítettem a szolokból. Ennek során a dietilén-glikol közegü ZnO szolokat centrifugáltam (Hettich Universal 30F , 2000 fordulat/perc, 2 óra), a felülúszó eltávolítása után az eredetivel megegyező koncentrációban etanolban (> 99,99\%, a.r., Molar Chemicals) diszpergáltam a részecskéket 1 perc ultrahangozás segítségével. Az etanolban lévő részecskéket centrifugálással ülepítettem (2000 fordulat/perc, 30 perc), dekantáltam, majd azonos mennyiségü etanolban újradiszpergáltam (1 perc ultrahang). A mosási ciklust még kétszer megismételtem a leírtakkal azonos módon. Az utolsó lépésben kapott üledéket szárítószekrényben $105^{\circ} \mathrm{C}$-on 12 óra alatt kiszárítottam.

\section{1 nm átlagos átméröjü ZnO részecskék átmosása vizes közegbe}

A mintázatok készítéséhez a 341 nm-es $\mathrm{ZnO}$ részecskék vizes közegü diszperziójára volt szükségem. Ehhez a törzsszol $300 \mu$ l-es részletét eppendorf csőben 5 percig centrifugáltam (Eppendorf MiniSpin) $12500 \mathrm{rpm}$ fordulatszámon, a felülúszó eltávolítása után nagy tisztaságú vízzel (Millipore, MilliQ Integral 3, vezetőképesség: 18,2 $\mathrm{mS} / \mathrm{cm}$ ) öntöttem fel a kiindulási koncentrációra, majd 1 perces ultrahangozással diszpergáltam. A mosási ciklust még kétszer ismételtem meg, végül a törzsszollal megegyező koncentrációban nagy tisztaságú vízben diszpergáltam a részecskéket.

\section{IV.1.4 Arany nanorészecskék preparálása}

Az arany nanorészecskék szintézisét a széleskörben használt Turkevich módszerrel végeztem [136]. A szintézis nagy előnye, hogy monodiszperz, szabályos gömb alakú részecskék képződnek, valamint a szintézis paramétereinek változtatásával hangolható a részecskeméret [137, 138]. Munkámhoz $10 \mathrm{~nm}$ átlagos átmérőjü részecskéket állítottam elö.

A szintézis során $58,25 \mathrm{ml}$ 0,209 $\mathrm{mmol} / \mathrm{dm}^{3} \mathrm{HAuCl}_{4}$ (>99\% Sigma Aldrich) vizes oldatot kevertetés közben forrásig melegítek. Amikor az oldat hőmérséklete eléri a $\sim 80^{\circ} \mathrm{C}$ -

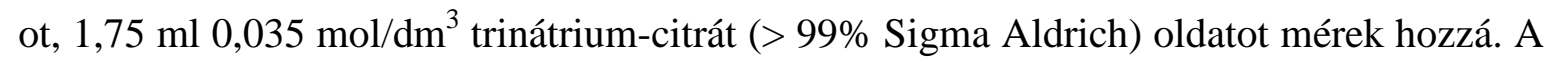
reakcióelegyet 1 órán át forralom, majd a fütés lekapcsolása után még néhány órát kevertetem. Az élénk vöröses színű szolt hűtőszekrényben tároltam. 


\section{IV.2 Langmuir-filmek előállítása víz/levegő határfelületen}

A kétféle mérettartományban elóállított $\mathrm{ZnO}$ részecskék, valamint sztearinsav vízfelszíni filmjeinek elóállítását és jellemzését a Kibron MicroroughS típusú kétkorlátos Langmuir-mérlegben végeztem. A kétkorlátos modell jellemzöje, hogy a monorétegü film kompresziója a két korlát egymás felé mozgásával valósul meg, szemben az egykorlátos modellel, amikor is a film a kád egyik végébe tömörül. A korlátok mozgásának megfelelően a felületi feszültség mérése a kád középső részénél történik. Ennek a típusnak a jellemzője egy speciálisan kialakított kád, amellyel jelentősen csökken a szubfázis térfogata. Ahogyan a képen is látszik a kád a felület jelentős részén nagyon sekély, a középső részén azonban egy mélyedést alakítottak ki, így lehetőség van a vízfelszíni film szilárd hordozóra történő átvitelére a Langmuir-Blodgett technikával. (Itt meg kell jegyeznem, hogy az eredeti üveg kád elszennyeződése miatt teflonból készíttetett másolattal dolgoztam.)

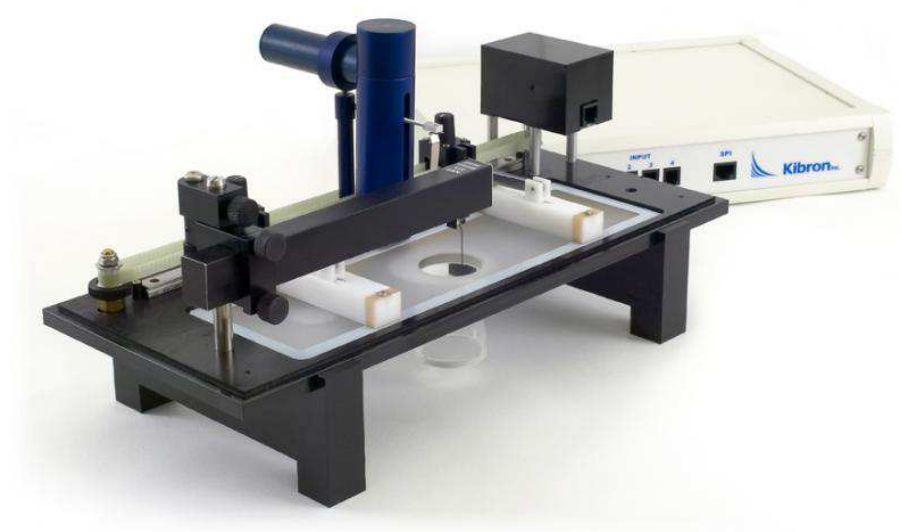

17. ábra. A mérésekhez használt Kibron MicroTroughS típusú Langmuir-mérleg.

A mintaelőkészítés során a törzsszolt 1 percre ultrahangfürdőbe tettem. A 3-7 nmes $\mathrm{ZnO}$ és PEI-vel stabilizált $\mathrm{ZnO}$ részecskék etanolos közegú szoljaihoz 1:2 térfogatarányban kloroformot (CHROMASOLV® Plus for HPLC, etanollal stabilizált, Sigma Aldrich) adtam, a 200-500 nm-es ZnO részecskék dietilén-glikolos közegủ szoljait 1:1 térfogatarányban hígítottam kloroformmal, a sztearinsavból (>99,5\%, Fluka) $0,1 \mathrm{mg} / \mathrm{ml}$ koncentrációjú kloroformos oldatot készítettem. A terítendő szolokat közvetlenül a vízfelszínre juttatás előtt 1 percre ultrahangfürdőbe tettem.

A kád előkészítése során etanollal nedvesített papírvattával többször áttöröltem azt, majd feltöltöttem ultratiszta vízzel (Millipore, MilliQ Integral 3, vezetőképesség: 18,2 
$\mathrm{mS} / \mathrm{cm})$. Ezután vízsugárszivattyú segítségével megtisztítottam a vízfelszínt és beállítottam a vízszintet.

A korlátok szélső állásában (maximális vízfelszíni terület) egy mikrofecskendő segítségével a vízfelszínre vittem a megfelelő mennyiségü terítőszolt vagy oldatot. A terítőfolyadék elpárolgását követően (5 perc) a korlátok egyenletes sebességü mozgatásával $\left(815 \mathrm{~mm}^{2} /\right.$ perc) csökkentettem a vízfelszíni film területét, miközben a müszert irányító számítógép regisztrálta az erőmérő által mért oldalnyomást a vízfelszín területének függvényében.

Az oldalnyomás - terület izotermákból meghatározható a Langmuir-filmre jellemző kontakt keresztmetszeti terület $\left(\mathrm{A}_{\mathrm{k}}, \mathrm{nm}^{2}\right)$, valamint a kollapszuspont paraméterei: oldalnyomás $\left(\pi_{c}, \mathrm{mN} / \mathrm{m}\right)$ és terület $\left(\mathrm{A}_{\mathrm{c}}, \mathrm{mN} / \mathrm{m}\right)$, a paramétereket az alábbi ábrán mutatom be (18. ábra).

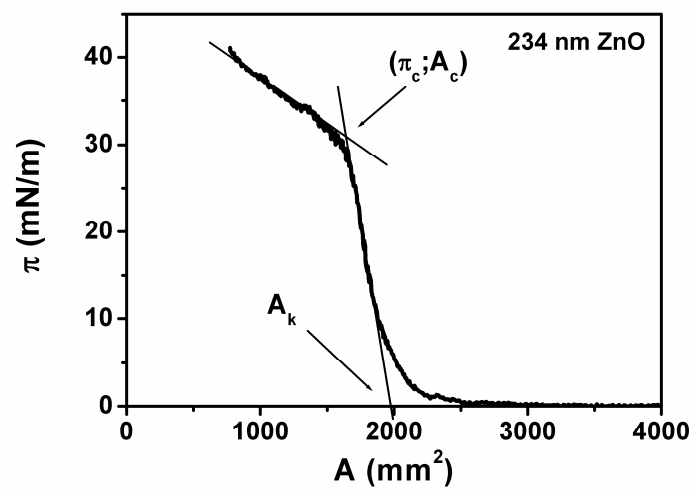

18. ábra. Az oldalnyomás $(\pi)$ vs. terület $(\mathrm{A})$ izotermából meghatározható paraméterek szemléltetése: $A_{k}$ : kontakt keresztmetszeti terület, $\pi_{\mathrm{c}}$ : kollapszus nyomás, $\mathrm{A}_{\mathrm{c}}$ : kollapszus terület.

A kontakt keresztmetszeti területből a vízfelszínre vitt részecskék számának ismeretében meghatározható az egy részecskére jutó terület $\left(\mathrm{A}_{1}, \mathrm{~nm}^{2}\right)$ :

$$
A_{1}=\frac{A_{k}}{N}=\frac{A_{k} \cdot d^{3} \pi \rho_{p}}{6 m},
$$

ahol $N$ a részecskék száma a vízfelszíni Langmuir-filmben, $d$ a részecskék átlagos átmérője, $\rho_{p}$ a részecskék sürüsége és $m$ a részecskék tömege a filmben. Egyetlen részecske területigénye elméleti számolás alapján is meghatározható a részecske köré írt hatszög területével $\left(\mathrm{A}_{\mathrm{H}}, \mathrm{nm}^{2}\right)$ :

$$
A_{H}=\frac{\sqrt{3}}{2} d^{2} .
$$




\section{IV.3 Szilárd hordozós filmek készítése}

\section{IV.3.1 Aranybevonatú hordozók készítése, felületkezelése}

A $\mathrm{ZnO}$ részecskék arannyal való plazmonikus csatolásának vizsgálatára arannyal bevont hordozókra készítettem filmeket, mintázatokat $\mathrm{ZnO}$ részecskékkel. Ezekhez a vizsgálatokhoz kétféle arany filmet használtam: (i) a IV.1.4 fejezetben leírtak szerint előállított arany nanorészecskék ún. spray coating (magyarul nagyjából porlasztásos filmképzés) technikával készített bevonata kvarc hordozón, (ii) SPR spektroszkópiában használatos $50 \mathrm{~nm}$ vastagságú folytonos arany filmmel bevont üveglap.

(i) A kvarc- és üveghordozókat krómkénsavban tisztítottam, desztillált vízzel öblítettem és nitrogén áramban szárítottam. Az arany részecskék szolját további kezelés nélkül használtam fel. A filmképzést fülke alatt végeztem. Ennek során a megtisztított kvarc- és üveglapokat egy tiszta lapon szorosan egymás mellé fektettem, forró levegővel (hajszárító) felmelegítettem, majd az arany szol egy részletét a felületükre porlasztottam. Száradás után addig ismételtem a filmképzést, amíg szabad szemmel jól látható rózsaszínes bevonat képződött rajtuk. A filmeket végül levegő atmoszférában hőkezeltem $400^{\circ} \mathrm{C}$-on 3 órán át. A kvarchordozós filmeket fluoreszcencia emissziós vizsgálatokra, az üveghordozós filmeket AFM mérésekre készítettem.

(ii) Az $50 \mathrm{~nm}$ vastag Au filmmel borított üveglapot a Platypus Technologies cégtől vásároltuk (típus: AU.0500.ALSI). A felszínét friss perkénsav oldatban (cc. $\mathrm{H}_{2} \mathrm{SO}_{4}$ és $30 \%$ $\mathrm{H}_{2} \mathrm{O}_{2}$ 3:1 térfogatarányú elegye) tisztítottam meg 5 perc alatt, majd desztillált vízzel öblítettem és nitrogén áramban szárítottam. Az így nyert felület túlságosan hidrofób volt a további célokra, így hidrofilizáltam azt: 24 órára 2\%-os 2-merkaptoetanol (>99,0\%, Sigma-Aldrich) etanolos oldatába merítettem, majd etanollal és desztillált vízzel öblítettem, végül nitrogén áramban szárítottam.

\section{IV.3.2 Langmuir-Blodgett-filmek}

A $\mathrm{ZnO}$ részecskék esetén hordozóként üvegből készült mikroszkóp tárgylemezt használtam, melyek mérete átlagosan $2,6 \mathrm{~cm} \times 3,8 \mathrm{~cm}$ volt. A pásztázó elektronmikroszkópos felvételekhez a vizsgálandó filmeket Si lapra építettem fel, a fluoreszcencia spektrumok méréséhez pedig kvarchordozós filmeket készítettem. Az 
előkészítés során a célom hidrofil felület előállítása volt, ehhez a hordozókat krómkénsavba merítettem legalább egy órára, majd desztillált vízzel öblítettem, és nitrogén áramban szárítottam. Sztearinsav esetében kvarc lapot vagy különböző aranybevonatú hordozókat használtam, ezek előkészítése a már ismertetett módon történt (IV.3.1).

A kád előkészítése (IV.2) után a korlátok szélső pozíciójában a filmhúzó feltét (lásd 17. ábra) segítségével a hordozót a vízbe merítettem $\mathrm{kb}$ a $2 / 3$ részéig. Ezt követően a terítőszolt vagy oldatot apró cseppekben, mikrofecskendő segítségével a vízfelszínre juttattam. A terítőfolyadék elpárolgása után a vízfelszín területét egyenletes sebességgel csökkentettem a megfelelő tömörségü film eléréséig. A Langmuir-Blodgett-filmeket állandó oldalnyomás mellett $2 \mathrm{~mm}$ /perc sebességgel húztam ki, majd levegőn szárítottam. Többrétegű filmek ezen eljárás ismétlésével állíthatók elő. Sztearinsav esetén a Z-típusú depozíciós módot alkalmaztam, ahol a molekulák a filmképzéskor fej-lánc érintkezésben vannak.

Ezzel a módszerrel állítottam elő egy- és többrétegü filmeket mindkét típusú ZnO részecskéből. A $3 \mathrm{~nm}$-es átlagos méretü $\mathrm{ZnO}$ részecskékből arannyal bevont hordozókra (IV.3.1.) építettem különböző filmeket. A fém és a félvezető közti távolság szabályozására sztearinsav Langmuir-Blodgett-filmeket építettem be (19. ábra).
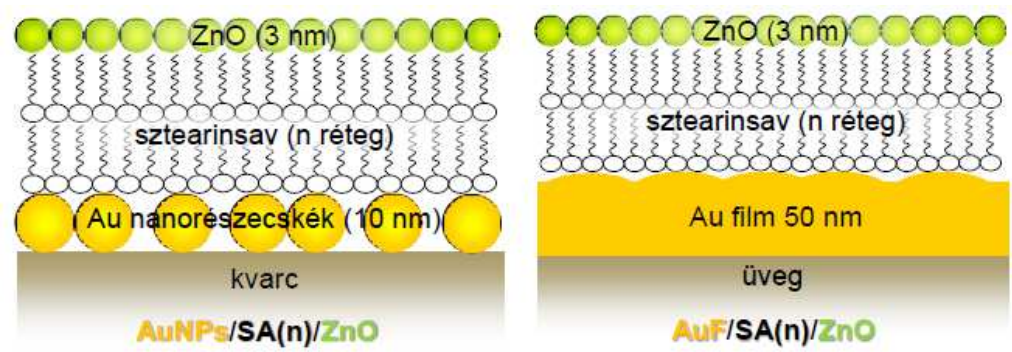

19. ábra. Az előállított Au-ZnO hibrid filmek felépítése.

a) $\mathrm{AuNPs} / \mathrm{SA}(\mathrm{n}) / \mathrm{ZnO}$ : Au nanorészecskék filmje (porlasztásos filmképzés) + n rétegszámú sztearinsav (Langmuir-Blodgett technika) + 1 réteg $\mathrm{ZnO}$ (Langmuir-Blodgett technika)

b) $\mathrm{AuF} / \mathrm{SA}(\mathrm{n}) / \mathrm{ZnO}$ : Au folytonos filmmel borított üveglap $+\mathrm{n}$ rétegszámú sztearinsav (LangmuirBlodgett technika) + 1 réteg $\mathrm{ZnO}$ (Langmuir-Blodgett technika)

\section{IV.3.3 Mintázott felületek}

A mintázatok készítéséhez önrendeződésen alapuló technikát használtam: hullámosított felszínü PDMS (polidimetilsziloxán) bélyegzők irányítják a részecskék rendeződését. A technika elvét a II.4.2. fejezetben mutattam be.

A hullámos felszínű bélyegző előállításához a PDMS prekurzor (Sylgard 184, Dow Corning, USA) és a térhálósító ágens (Sylgard 184 curing agent, Dow Corning, USA) 10:1 
tömegarányú keverékét egy $10 \mathrm{~cm}$ x $10 \mathrm{~cm}$ x $1 \mathrm{~cm}$-es lapos üveg kádba öntöttem, Petricsészvel lefedve 1 nap alatt képződik és megszilárdul a térhálós PDMS gumi. A tömböt az üveg kádból kivéve $\mathrm{kb} 1 \mathrm{~cm} \times 4 \mathrm{~cm}$-es darabokra vágtam fel. A PDMS csíkot két végénél egy erre alkalmas szerkezetbe befogtam, majd az eredeti hosszának 125\%-ára nyújtottam meg és oxigén plazmában (Flecto10, Plasma Technology, Németország) oxidáltam a felszínét 10 vagy 20 perc kezelési idő, 0,2 mbar nyomás és $0,1 \mathrm{~kW}$ mellett. A plazma kezelés után a rugalmas PDMS tömb relaxálásakor az oxidálás hatására merevvé vált felszíni réteg hullámos alakot vesz fel. A bélyegzök felszíne az előállítást követően hidrofil jellegü, de nagyjából 3 hét öregítés után teljesen hidrofóbbá válik. A felület oxigén plazmában történő kezeléssel újra hidrofilizálható.

A mintázatok hordozójaként perkénsavban megtisztított kvarc- és üveglapokat vagy hidrofilizált arany felületeket (IV.3.1) használtam. A perkénsav oldatban megtisztított üvegfelszín negatív felületi töltésü. A hordozó felületmódosítására aminopropiltrietoxiszilánt (APTES />99\%, Aldrich/, vákuum exszikkátorban 1 óra gőzadszorpció), poli-L-lizin-polietilénglikol kopolimert (PLL-g-PEG /PLL(20 kDa)-hez oldalláncként kapcsolva PEG(2 kDa), g = 3,0 - 4,0, SuSoS AG, Svájc/, $1 \mathrm{mg} / \mathrm{mL}$ vizes oldat, 20 perc adszorpció) és kétféle molekulatömegü polietilénimint ( $\mathrm{PEI}_{\mathrm{LMW}}$ /elágazó, MW: 800/, Aldrich és $\mathrm{PEI}_{\mathrm{HMW}}$ /MW: 25000, Aldrich/, 1g/L vizes oldat, 5 perc adszorpció) használtam.

A 341 nm-es $\mathrm{ZnO}$ részecskéket minden kísérlethez frissen vittem át vízbe (IV.1.3. fejezet), ugyanis vizes közegben csak viszonylag rövid ideig maradnak egyedi részecskékként diszpergálva (nagyjából 1 nap után megjelennek a néhány részecskéből álló aggregátumok, azonban nagymértékủ aggregáció több hónap elteltével sem tapasztalható). A pozitív felületi töltésü $\mathrm{ZnO}$ részecskék felületmódosítására negatív töltésü polimereket, polisztirol-szulfonátot (PSS, MW: 70,000, Aldich) és poliakrilsavat (PAA, a. r., Fluka) használtam (vizes közegü törzsszol centrifugálása után újradiszpergálás 1g/L polimer oldatban, keverés 20 percig, majd centrifugálás és mosás 3-szor desztillált vízben).

A mintázatképzési eljárás rendkívül egyszerü: a megfelelően elökészített hordozó felszínére cseppentettem $10 \mu 1 \mathrm{ZnO}$ részecskéket tartalmazó szolt majd óvatosan rátettem a bélyegzőt és az egészet lefedtem egy petri-csészével. Száradás után (12 óra) óvatosan eltávolítottam a bélyegzőt. 


\section{IV.3.4 Random szerkezetü filmek készítése}

A $\mathrm{ZnO}$ részecskéket szabálytalan elrendeződésben tartalmazó filmeket adszorpcióval hoztam létre. A 341 nm-es részecskék szolját vizes közegbe vittem át (IV.1.3. fejezet), a kvarc-, üveg- és arannyal bevont üveghordozók felszínét friss perkénsav oldatban tisztítottam, további kezelés nem történt. A filmkészítéshez a hordozókat lefektettem egy tiszta felszínre, $200 \mu \mathrm{ZnO}$ részecskéket tartalmazó szolt cseppentettem a felületükre, majd 1 perc elteltével desztillált vízzel öblítettem és nitrogén áramban szárítottam a filmeket.

\section{IV.4 Vizsgálati módszerek}

\section{IV.4.1 Transzmissziós elektronmikroszkópia (TEM)}

$\mathrm{A} \mathrm{ZnO}$ és $\mathrm{Au}$ részecskék méretét transzmissziós elektronmikroszkóppal (Philips CM-10, SZTE, ÁOK, Pathológiai Intézet; FEI Tecnai G² 20 X-TWIN, SZTE, TTIK, Alkalmazott és Környezetkémiai Tanszék; valamint Hitachi S-4700 pásztázó elektronmikroszkóp transzmissziós üzemmód, SZTE, TTIK, Alkalmazott és Környezetkémiai Tanszék) készített felvételek alapján jellemeztem. A részecskeméreteloszlás meghatározását az Image Tool 3.0 szoftver segítségével végeztem, minden esetben legalább 200 db részecske méretének figyelembe vételével.

A $\mathrm{ZnO}$ részecskék esetén a minták előállításához a filmmérlegben elkészítettem a vizsgálandó részecskék Langmuir-filmjét (IV.2 fejezet). A tömör filmből kanalazó mozdulattal mintát vettem egy rézrácsra (gridre). A preparátumot szobahőmérsékleten szárítottam. Az arany részecskék esetén a szolból rézrácsra felvitt cseppet infra lámpa alatt beszárítottam.

\section{IV.4.2 Röntgendiffrakció (XRD)}

Az előállított $\mathrm{ZnO}$ részecskék kristályosságát röntgendiffrakciós mérésekkel jellemeztem. A mérések a IV.1.1 és a IV.1.3 pontokban leírtak szerint előállított pormintákról a Philips röntgendiffraktométerrel (PW 1830 generátor, PW 1820 goniométer, $\mathrm{CuK}_{\alpha}$ sugárzás: $\lambda=0,1542 \mathrm{~nm}, 40 \mathrm{kV}, 35 \mathrm{~mA}, 1 \mathrm{~mm}$-es rés) 
szobahőmérsékleten a $20-80^{\circ}(2 \Theta)$ szögtartományban. A sztearinsavból felépített többrétegü Langmuir-Blodgett-filmek szerkezetének jellemzésére is XRD mérések készültek, amelyeknél a mérési szögtartomány 0,5 - $60^{\circ}(2 \Theta)$ volt.

A Scherrer-egyenlet felhasználásával a csúcsok vonalszélesedése alapján kiszámoltam a mintára jellemző átlagos kristályméretet $(d)$ :

$$
d=\frac{k \lambda}{\beta \cos \Theta},
$$

ahol $\lambda$ a röntgensugárzás hullámhossza $(\lambda=0,1542 \mathrm{~nm}), \beta$ a félértékszélesség, $\Theta$ a diffrakció szöge, $k$ pedig konstans.

\section{IV.4.3 Lézerdiffrakció}

A ZnO részecskékből kialakított sávos mintázatok hullámhosszát lézerdiffrakciós módszerrel is meghatároztam egy házilag összeállított berendezéssel. Az üveghordozón kialakított mintázatot piros $(670 \pm 10 \mathrm{~nm}$, Class IIIa laser pionter, teljesítménye max. $3 \mathrm{~mW})$ illetve zöld $(532 \pm 10 \mathrm{~nm}$, Class II laser pointer, teljesítménye $<1 \mathrm{~mW})$ lézerforrással felülről megvilágítottam, majd a meghatározott távolságban alatta lévő fehér lapon bejelöltem az áteső direkt fényt, továbbá az első- és a másodrendü diffrakciók helyét. A mintázat hullámhossza $(\Lambda, \mathrm{nm})$ a következő egyenlettel meghatározható [139]:

$$
\Lambda=\frac{2 \pi}{q},
$$

ahol a $q$ szórásvektor az alábbi kifejezéssel számolható [139]:

$$
q=\frac{4 \pi}{\lambda} \sin \frac{\theta}{2}
$$

ahol $\lambda$ a lézerfény hullámhossza $(\mathrm{nm}), \theta$ a diffrakciós szög. A (9) képlet azonos a SAXS méréseknél (IV.4.5) a szórásvektor (XI.1) meghatározására használt egyenlettel.

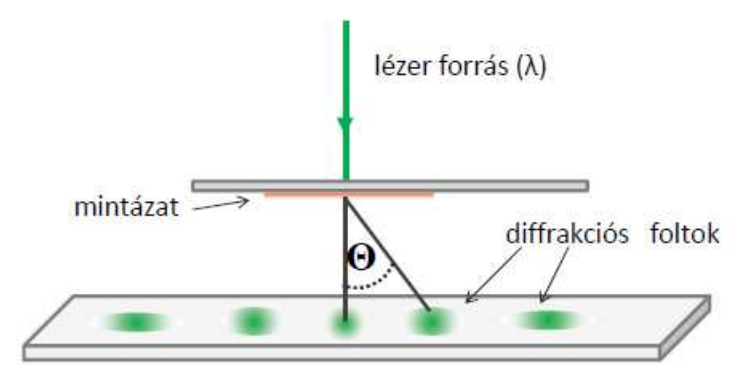

20. ábra. A lézerdiffrakciós mérés elve. 


\section{IV.4.4 $\mathrm{N}_{2}$ adszorpciós-deszorpciós mérések}

A ZnO részecskék fajlagos felületét, pórusosságát és sürüségét $\mathrm{N}_{2}$ gázadszorpciós izotermák mérése alapján jellemeztem. Az izotermák felvételéhez a korábban leírtak (IV.1.3. alfejezet) szerint nyert pormintákat használtam fel, amelyeket $100^{\circ} \mathrm{C}$-on egy éjszakán át $10^{-2}$ Torr nyomáson előkezeltem. A mérések a Micrometrics Gemini 2375 típusú automata szorptométerrel készültek $77 \mathrm{~K}$ hőmérsékleten, a mért adszorpciós és deszorpciós izotermák kiértékelését program végezte: a BET egyenlet alapján fajlagos felület értékeket, a BJH módszer felhasználásával pedig pórusméret-eloszlást kaptam [140]. A BJH módszerrel nyert pórustérfogat eredményeket használtam fel a részecskék porozitásának és sürüségének kiszámítására.

\section{IV.4.5 Kisszögü röntgenszórás (SAXS)}

A kisszögü röntgenszórási mérések során a 200-500 nm-es ZnO részecskék szerkezetét, strukturáltságát jellemeztem. A szolokból nyert porminták (IV.1.3. alfejezet) analízise egy Philips PW 1820 típusú generátorral előállított $\mathrm{CuK} \alpha$ sugárzás alkalmazásával $(\lambda=0,154 \mathrm{~nm}, 40 \mathrm{kV}, 30 \mathrm{~mA})$ készült. A primer sugárzás egy Ni filteren keresztül jut a KCEC/3 típusú kompakt Kratky-kamerába, amelyben a sugár szélessége 15 mm, vastagsága $40 \mu \mathrm{m}$. A mérések vákuum atmoszférában történtek. A porminták egy 0,5 mm vastagságú mintatartóban lettek elhelyezve. A szórt sugárzás intenzitását az ASA szoftver által vezérelt helyérzékeny detektor (PDS 50M) határozta meg a $2 \Theta=0,05-8^{\circ}$ szögtartományban. A röntgenabszorpciós intenzitások $\left(A_{S}, A_{B}\right)$ a mozgó rés módszerrel lettek meghatározva. A Kratky-kamerában mért $\mathrm{I}_{\mathrm{S}}(\mathrm{h})$ szórásfüggvényből a háttér szórását $\mathrm{I}_{\mathrm{B}}(\mathrm{h})$ le kell vonni és az adatokat normálni kell, hogy a minta szerkezeti paramétereinek meghatározására alkalmas függvényt kapjunk. Az eredmények kiértékelésének menetét a Függelék XI.1 fejezetében részletezem.

\section{IV.4.6 Dinamikus fényszórásmérés (DLS), ל-potenciál mérése}

A dinamikus fényszórási (DLS) és elektrokinetikai potenciál ( $\zeta$-potenciál) méréseket a Malvern Zetasizer NanoZs típusú készülékkel végeztem, amely egy 632,8 nm 
hullámhosszú He-Ne lézer fényforrással müködik. DLS mérésekkel jellemeztem a 3-7 nm-es $\mathrm{ZnO}$ részecskék ill. aggregátumaik méretét, a $341 \mathrm{~nm}$ átlagos átmérőjü $\mathrm{ZnO}$ részecskék vizes közegű szoljain pedig a DLS mérések mellett ל-potenciál méréseket is végeztem. A vizsgálatokhoz a törzsszolokat további hígítás nélkül használtam fel. A méret meghatározásához a mintákat üveg mintatartó küvettába, az elektrokinetikai potenciál meghatározásához pedig polisztirolból készült U-alakú kapilláris mintatartóba töltöttem, a mérési eredményeket három párhuzamos mérés átlagából számítottam.

\section{IV.4.7 UV-látható spektroszkópia}

A 3-7 nm-es $\mathrm{ZnO}$ részecskéket tartalmazó etanolos közegű szolok UV-látható abszorbancia spektrumait a részecskék méretének és gerjesztési küszöbenergiájának meghatározására használtam. A spektrumokat az OceanOptics USB2000 típusú spektrofotométerrel mértem kvarc küvettában, a fotométer felbontása $0,3 \mathrm{~nm}$, háttérként abszolút etanolt használtam, a mérésekhez a törzsszolt minden esetben 50-szeresére hígítottam abszolút etanollal.

Az abszorbancia spektrumokból meghatározható a részecskék gerjesztési küszöbenergiája valamint a részecskék mérete is [21]. Az abszorbancia spektrumokból a részecskeméret az

$$
1240 / \lambda_{1 / 2}=3,301+294 / D^{2}+1,09 / D
$$

egyenlet alapján számolható, ahol $\lambda_{1 / 2}$ az abszorbancia spektrum 300-400 nm közötti részének inflexiós pontja (meghatározható a mért spektrum differenciálásával), $D$ pedig a részecskék átmérője $\AA$ mértékegységben. A $\mathrm{ZnO}$ részecskék méretkvantált tulajdonságának jellemzéséhez kiszámoltam a részecskék gerjesztési küszöbenergiáját a Tauc-módszer segítségével. Ennek során ábrázoltam az $(A h v)^{2}$ vs. ( $\left.h v\right)$ függvényt, ahol $A$ az adott hullámhosszon mért abszorbancia, $h v$ pedig a fotonenergia $(\mathrm{eV})$. A lineáris részre illesztett egyenes és az abszcissza metszéspontja adja meg a gerjesztési küszöbenergia értékét.

A 10 nm-es $\mathrm{Au}$ részecskéket tartalmazó szolok UV-Vis spektrumait a részecskék plazmonikus tulajdonságának jellemzésére mértem az OceanOptics USB2000 típusú spektrofotométerrel kvarc küvettában, a fotométer felbontása $0,3 \mathrm{~nm}$, háttérként nagy tisztaságú vizet, a mérésekhez a törzsszolt további hígítás nélkül használtam. 
A 3-7 nm-es és a 200-500 nm-es ZnO részecskékből üveg és kvarchordozóra felépített Langmuir-Blodgett-filmeket, mintázatokat és random szerkezetü filmeket jellemeztem UV-látható abszorbancia illetve transzmittancia spektrumokkal. A méréseket az Ocean Optics USB4000 és az Ocean Optics CHEM 2000 típusú diódasoros spektrofotométerekkel végeztem, a felbontás $0,3 \mathrm{~nm}$, referenciaként a levegő spektrumát mértem. A 234 nm-es átlagos átmérőjű $\mathrm{ZnO}$ részecskék többrétegü filmjeinek reflexió spektrumát az Ocean Optics USB4000 típusú diódasoros fotométerrel végeztem, amelyhez optikai kábelen keresztül egy házi tervezésü reflexiós mérőcellát csatlakoztattam, a spektrumok felvételét $45^{\circ}$-os elrendezésben valósítottam meg, referenciaként tiszta üveglapot használtam, a készülék felbontása $0,3 \mathrm{~nm}$.

\section{IV.4.8 Atomerő mikroszkópia (AFM)}

A 3-7 nm-es $\mathrm{ZnO}$ részecskékből épített többrétegü Langmuir-Blodgett-filmek valamint az arannyal bevont hordozók szerkezetét atomerő mikroszkóppal készített felvételekkel jellemeztem. A vizsgálatokhoz üveghordozóra készítettem el a filmeket. A méréseket a Digital Instruments Nanoscope III típusú atomerő mikroszkóppal készítettem tapogató (tapping) üzemmódban, a készülék piezo kristálya x és y irányban $12,5 \mu \mathrm{m}, \mathrm{z}$ irányban $3 \mu \mathrm{m}$ mozgásra képes. A leképezéshez szilícium tapping tüt (Veeco Nanoprobe Tips RTESP modell) használtam $(125 \mu \mathrm{m}, 300 \mathrm{kHz})$. A kiértékelés során meghatároztam a mintákra jellemző felületi érdesség értékét a következő egyenlet segítségével:

$$
R M S=\sqrt{\frac{\sum_{i=1}^{N}\left(Z_{i}-Z_{\text {att }}\right)^{2}}{N},}
$$

ahol $Z_{a \text { atl }}$ egy adott területre jellemző átlagos magasság érték, $Z_{i}$ az i-edik pontban mért magasság, $N$ az adott területen található adatpontok száma.

\section{IV.4.9 Pásztázó elektronmikroszkópia (SEM)}

Az autoklávban előállított 200-500 nm-es ZnO részecskék morfológiáját, felületi struktúráját, Langmuir-Blodgett-filmjeik és a mintázatok rendezettségét pásztázó elektronmikroszkópos képekkel jellemeztem. A kvarchordozón elkészítet minták felszínére vékony (néhány $\mathrm{nm}$ ) arany filmet párologtattam a mintafelszín elektromos 
vezetőképességének javátására. A mérések a Hitachi S-4700 típusó pásztázó elektronmikroszkóppal készültek (SZTE, TTIK, Alkalmazott és Környezetkémiai Tanszék) 5 kV gyorsító feszültség mellett. A képek kiértékelését az Image Tool 3.0 szoftver segítségével végeztem.

\section{IV.4.10 Fluoreszcencia spektroszkópia}

A $\mathrm{ZnO}$ részecskés szolok illetve filmek fotoemissziós tulajdonságainak jellemzéséhez fluoreszcencia emissziós spektrumokat mértem a Horiba Jobin Yvone Fluoromax-4 spektrofluoriméteren. A 3-7 nm-es ZnO részecskék etanolos közegủ szoljait abszolút etanollal 50-szeresre hígítottam. A filmek méréséhez egy porminták és hordozós vékonyrétegek számára kialakított speciális mintatartó feltétet használtam. A mérésekhez a készülék kalibrációja a desztillált víz 397 nm-nél található Raman emissziójához történt, gerjesztő forrásként $280 \mathrm{~nm}, 300 \mathrm{~nm}$, valamint $350 \mathrm{~nm}$-es hullámhosszú fénysugarat alkalmaztam, a belépő és a kilépő rés egyaránt $5 \mathrm{~nm}$, a felbontás $1 \mathrm{~nm}$ volt, az integrációs idő pedig $0,1 \mathrm{~s}$ volt. A spektrumok kiértékelésénél az oldószert (etanol) illetve az Au-ZnO hibrid filmeknél a csak ZnO-t tartalmazó filmeket használtam referenciaként. 


\section{EREDMÉNYEK I. RÉSZ: 3-7 NM-ES CINK-OXID RÉSZECSKÉK ÉS FILMJEIK}

Ebben a fejezetben a 3-7 nm-es mérettartományban előállított $\mathrm{ZnO}$ részecskékkel kapcsolatos eredményeket tárgyalom. Bemutatom, hogy az etanolos közegü szoljaikban Ostwald-féle öregedés miatt idővel nő a részecskék mérete, amelyet UV-látható abszorbancia spektrumok eltolódása alapján határoztam meg. Különböző korú, ezáltal különböző méretü részecskéket tartalmazó szolok fluoreszcencia emissziós vizsgálatán keresztül jellemzem a részecskék méretfüggő emissziós tulajdonságait. Létrehotzam ezen részecskék Langmuir- és Langmuir-Blodgett-filmjeit és jellemzésükre többek között UVlátható abszorbancia- és fluoreszcencia spektrumokat mértem, amelyek kiértékelésével rámutatok, hogy a részecskék a filmben megőrzik látható emissziójukat. $\mathrm{Au}$ és $\mathrm{ZnO}$ tartalmú hibrid filmeket állítottam elő, és jellemzem az $\mathrm{Au}$ hatását a $\mathrm{ZnO}$ részekék emissziójára. Az Au-ZnO távolság finom hangolására sztearinsav Langmuir-Blodgettfilmeket építettem közéjük különböző rétegszámban. A plazmonikus kölcsönhatás következtében létrejövő fluoreszcencia emisszió változását az $\mathrm{Au}-\mathrm{ZnO}$ távolság és az $\mathrm{Au}$ nanostrukturáltságának függvényében elemzem.

\section{V.1 ZnO és Au nanorészecskék jellemzése}

\section{V.1.1ZnO részecskék}

$\mathrm{Az}$ etanolos közegben szintetizált $\mathrm{ZnO}$ részecskék és a PEI-vel stabilizált $\mathrm{ZnO}$ részecskék morfológiájának jellemzésére transzmissziós elektronmikroszkópos képek készültek (21. ábra). A felvételekről megállapítható, hogy a részecskék közel gömb alakúak és a méretük $5 \mathrm{~nm}$ alatt van, azonban a pontos méret és méreteloszlás nem határozható meg. A részecskék kristályosságának jellemzésére röntgendiffrakciós mérések készülttek. A 22. ábra mutatja a $\mathrm{ZnO}$ részecskék diffraktogramját, amelyen $31,70^{\circ}$-nál,

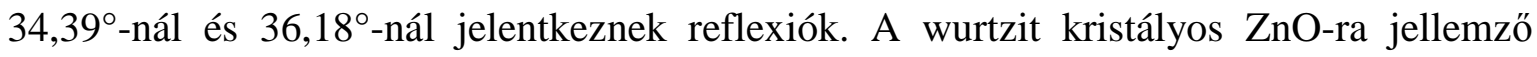

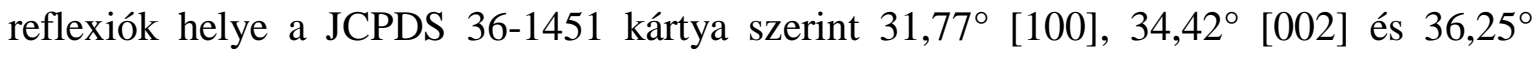
[101], amelyekkel jó egyezést mutatnak a mért diffraktogramok, így megállapítható, hogy az előállított részecskék wurtzit kristályos $\mathrm{ZnO}$ nanorészecskék. 

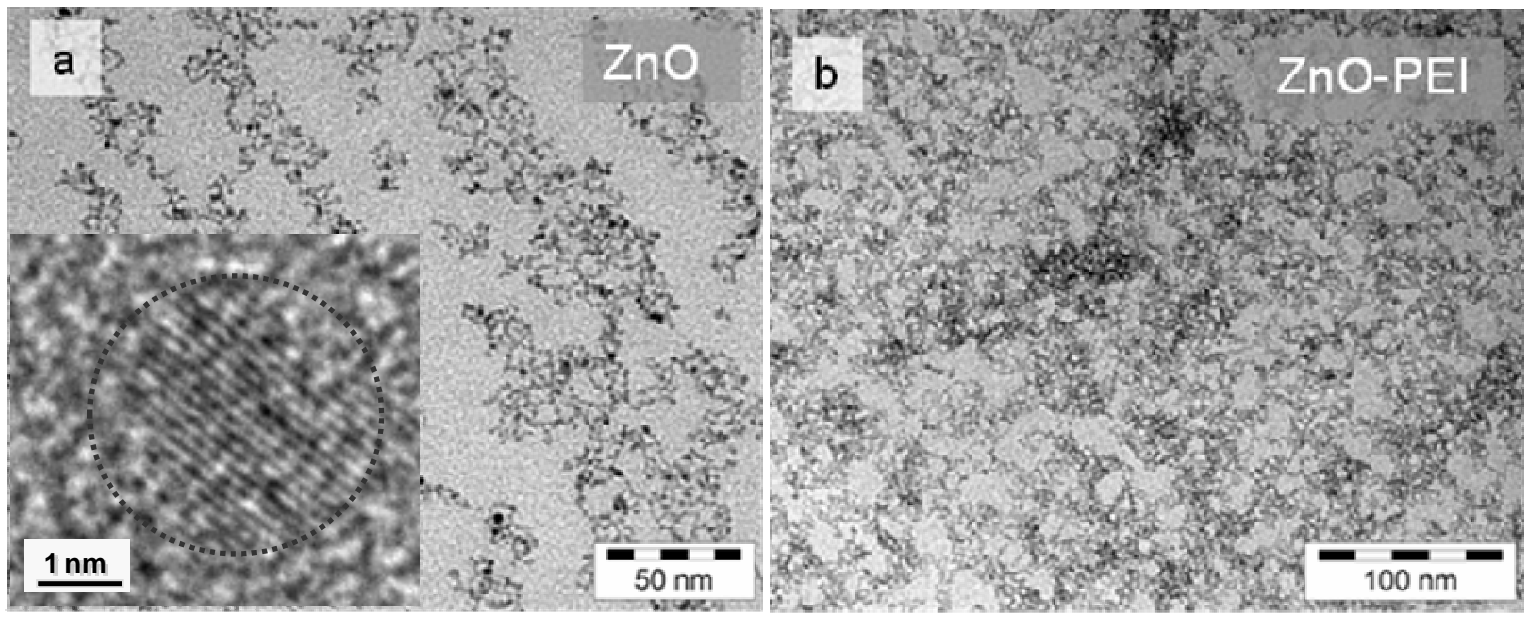

21. ábra. A módosítatlan és a PEI-vel borított ZnO részecskék TEM képe.

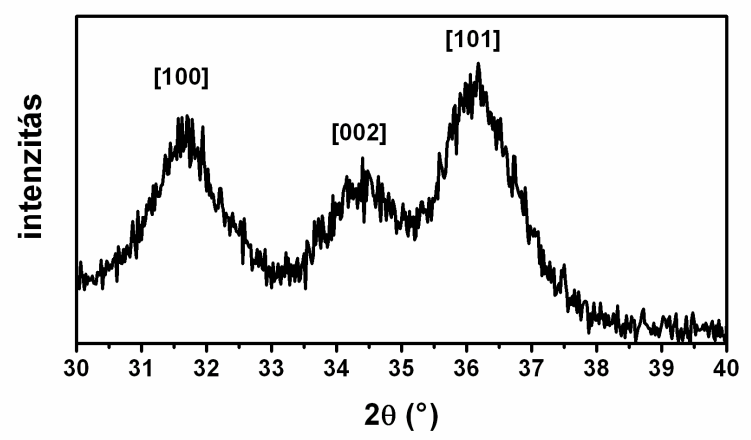

22. ábra. A ZnO részecskék pormintájáról készült XRD diffraktogram.

A részecskék Ostwald-féle öregedését a módosítatlan, szobahömérsékleten tárolt $\mathrm{ZnO}$ szol esetén tanulmányoztam alaposabban. UV-Vis abszorbancia mérésekkel és röntgendiffrakciós módszerrel jellemeztem a részecskék méretét, dinamikus fényszórásméréssel pedig jellemeztem az aggregációt.

A 23. ábra a) részében látható a módosítatlan, szobahőmérsékleten tárolt $\mathrm{ZnO}$ részecskék UV-Vis abszorbancia spektrumának változása a szintézist követő 10 napos időintervallumban. Vörös eltolódás figyelhető meg a spektrumokon, aminek az oka a részecskék méretének növekedése. Az Ostwald-féle öregedési folyamat során a kisebb részecskék a nagyobb oldhatóságuk miatt nagyobb arányban oldódnak fel, miközben az oldhatósági korlát miatt kiváló anyag a nagyobb részecskék felületére kristályosodik ki. A mért spektrumokból a (10) egyenlet alapján kiszámítható a részecskeméret. Az abszorbancia spektrumokból meghatározható továbbá a részecskék gerjesztési küszöbenergia (,band gap”) értéke (IV.4.7 alfejezet), amely jellemző a részecskék 
méretkvantáltságára. A 23. ábra b) része a részecskék abszorbancia spektrumának Taucreprezentációját mutatja, amelyből meghatároztam a gerjesztési küszöbenergiát. A 24. ábra összefoglalja a módosítatlan, szobahőmérsékleten tárolt $\mathrm{ZnO}$ részecskék UV-Vis spektrumai alapján kapott eredményeket: a részecskeméret és a gerjesztési küszöbenergia változása időben. Látható, hogy a vizsgált 10 napos időintervallumban a részecskék mérete 3 nm-ről nagyjából 7 nm-re nő és ezzel párhuzamosan a gerjesztési küszöbenergia értéke 3,63 eV-ról lecsökken 3,37 eV-ra, vagyis a tömbfázisú ZnO-nak megfelelö értékre.

a)

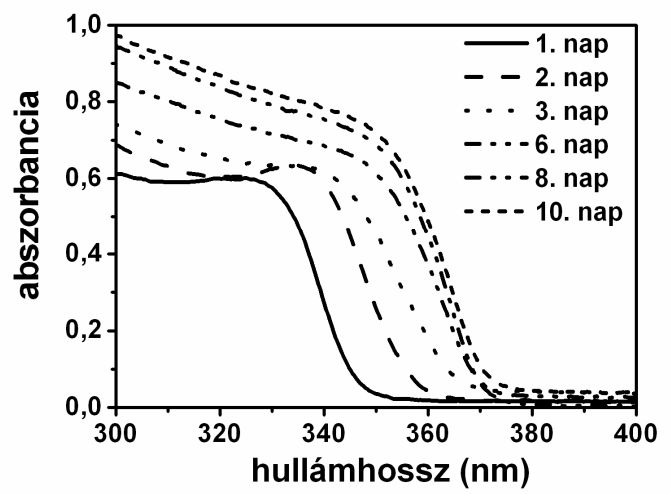

b)

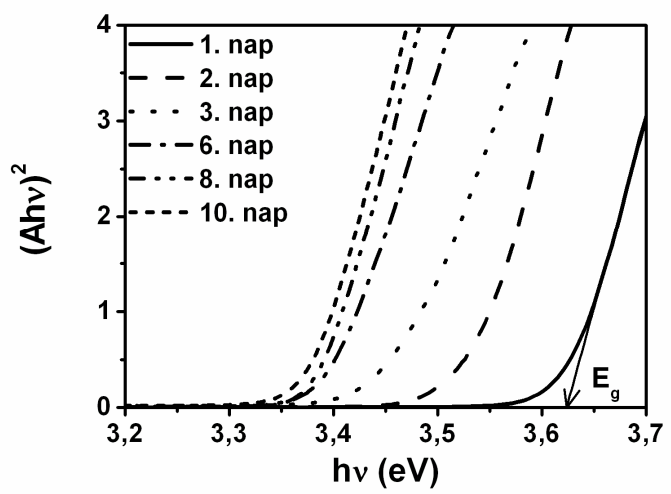

23. ábra. a) A ZnO részecskéket tartalmazó szol UV-Vis abszorbancia spektrumai a szintézist követő napokban. b) A mért abszorbancia spektrumok Tauc-reprezentációja a részecskék gerjesztési küszöbenergiájának meghatározásához.

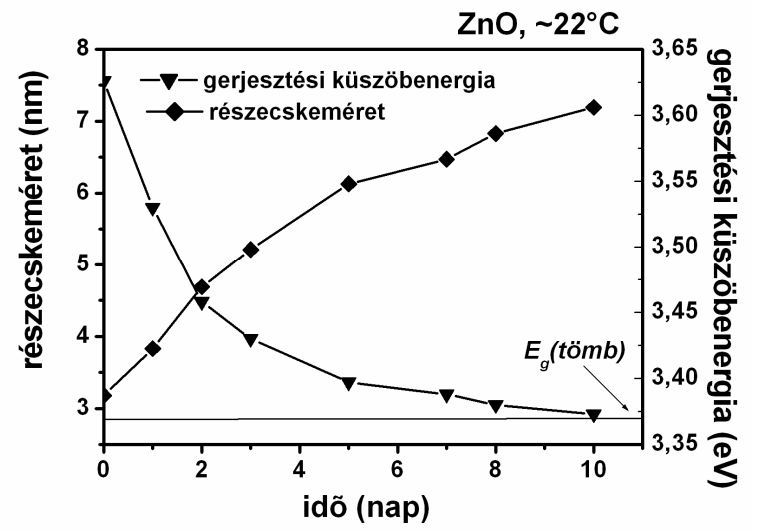

24. ábra. A részecskék mérete és gerjesztési küszöbenergiája az idő függvényében.

A módosítatlan, szobahőmérsékleten tárolt $\mathrm{ZnO}$ szolokat jellemeztem továbbá XRD és DLS mérésekkel is, a vizsgált 10 napos időintervallumban kapott eredményeket a 2. táblázatban foglaltam össze. A jobb megértés kedvéért a táblázatban feltüntettem az UV-Vis abszorbancia spektrumok alapján meghatározott értékeket is. Látható, hogy az abszorbancia spektrumokból és a röntgendiffrackciós módszerrel a Scherrer-egyenlet 
alapján ((7) egyenlet) meghatározott értékek jó egyezést mutatnak, ugyanakkor a dinamikus fényszórásmérés során nagyobb értékeket kaptam. A DLS mérések a részecskék hidrodinamikai átmérőjéről adnak információt, amely minden esetben nagyobb a tényleges méretnél. A részecskeméret növekedése mellett egyre jelentősebb a részecskék aggregációja is. A szintézist követően az aggregáció nem vagy nagyon kis mértékben figyelhető meg. Idővel azonban a részecskék összetapadnak, aggregálódnak, melynek eredményeképpen a tizedik napra közel 100 nm átmérőjü aggregátumok találhatók a szolban.

2. táblázat. A részecskeméret követése az előállítás utáni napokban UV-Vis abszorbancia, XRD és DLS módszerekkel.

\begin{tabular}{llccccccc}
\hline Idő (nap) & & $\mathbf{1}$ & $\mathbf{2}$ & $\mathbf{3}$ & $\mathbf{4}$ & $\mathbf{5}$ & $\mathbf{8}$ & $\mathbf{1 0}$ \\
\hline \multirow{2}{*}{ Részecskeméret (nm) } & UV-Vis & $\mathbf{3 , 2}$ & $\mathbf{3 , 8}$ & $\mathbf{4 , 7}$ & $\mathbf{5 , 2}$ & $\mathbf{5 , 6}$ & $\mathbf{6 , 4}$ & $\mathbf{7 , 1}$ \\
& XRD & $\mathbf{3 , 7}$ & $\mathbf{4 , 1}$ & $\mathbf{4 , 9}$ & $\mathbf{5 , 5}$ & $\mathbf{5 , 8}$ & $\mathbf{6 , 7}$ & $\mathbf{7 , 2}$ \\
& DLS & $\mathbf{1 4}$ & $\mathbf{1 8}$ & $\mathbf{2 3}$ & $\mathbf{3 3}$ & $\mathbf{5 1}$ & $\mathbf{6 8}$ & $\mathbf{9 1}$ \\
\hline
\end{tabular}

A szolok stabilitásának növelésére kétféle módszert alkalmaztam: alacsony hömérsékletü $\left(\sim 5^{\circ} \mathrm{C}\right)$ tárolás, illetve polietilénimin (PEI) mint sztérikus stabilizáló ágens jelenlétében állítottam elő a $\mathrm{ZnO}$ részecskéket. A különböző módon stabilizált szolok jellemzésére UV-Vis abszorbancia spektrumokat mértem, majd a (10) egyenlet segítségével meghatároztam a részecskeméretet. A 25. ábra foglalja össze a különböző módon kezelt és tárolt szolok esetében kapott eredményeket.

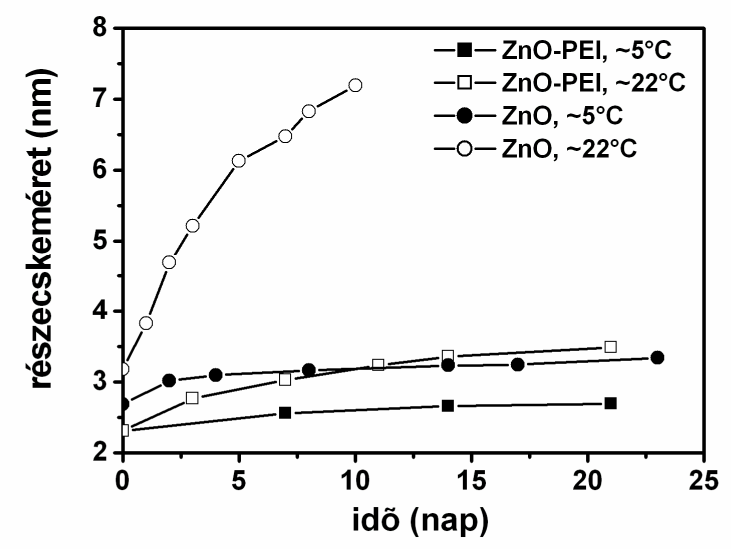

25. ábra. A módosítatlan és a PEI-vel borított részecskék méretének változása az időben, szobahőmérsékletü és alacsony hőmérsékletủ tárolás esetén. 
Látható, hogy mind a tárolási hőmérséklet csökkentésével, mind a PEI alkalmazásával jelentős mértékben sikerült lassítani az öregedési folyamatot. A pozitív töltésü PEI fizikai adszorpció révén a negatív töltésü $\mathrm{ZnO}$ részecskék felületére kötődött, gátolva a részecskék Ostwald-féle öregedését. Meg kell említeni, hogy a részecskék felületének polielektrolittal való borítása sikeresen lassította az öregedést, azonban nem állította meg azt. Megállapítható továbbá, hogy PEI jelenlétében végzett szintézis során kisebb méretü részecskék képződnek, ugyanis a polielektrolit a részecskék képződését követően azonnal képesek azok felületére adszorbeálódni és gátolni a további növekedést. A tárolási hőmérséklet fontos szerepe szintén jól látszik a görbéken. Alacsony hőmérsékletű tárolással jelentősen lassítható az öregedési folyamat. A PEI-vel stabilizált, alacsony hőmérsékleten tárolt minta mutatja a legnagyobb stabilitást, az öregedési folyamatot gyakorlatilag sikerült megállítani.

Ahogy fentebb részleteztem, a $\mathrm{ZnO}$ részecskék esetében látott öregedési folyamat során a részecskeméret nő. Ezt a folyamatot használtam fel arra, hogy meghatározzam a részecskék méretfüggő fluoreszcencia emissziós tulajdonságait. A fluoreszcencia emissziós mérésekkel párhuzamosan elvégzett abszorbancia mérésekből megállapítottam a részecskék méretét, a fluoreszcencia emissziós spektrumok kiértékelésével pedig jellemeztem az emissziós tulajdonságokat. Három különböző gerjesztési hullámhossz esetén végeztem méréseket, hogy tanulmányozzam a gerjesztési energia hatását.

A 26. ábra a) részében látható a módosítatlan $\mathrm{ZnO}$ részecskék esetén $280 \mathrm{~nm}$-es gerjesztő forrással mért emissziós spektrumai az UV tartományban, a b) ábrarészen pedig a látható tartományban. A 27. ábra a PEI-vel módosított ZnO részecskék 350 nm-es gerjesztő forrás esetén mért emissziós spektrumait mutatja be a látható tartományban.

a)

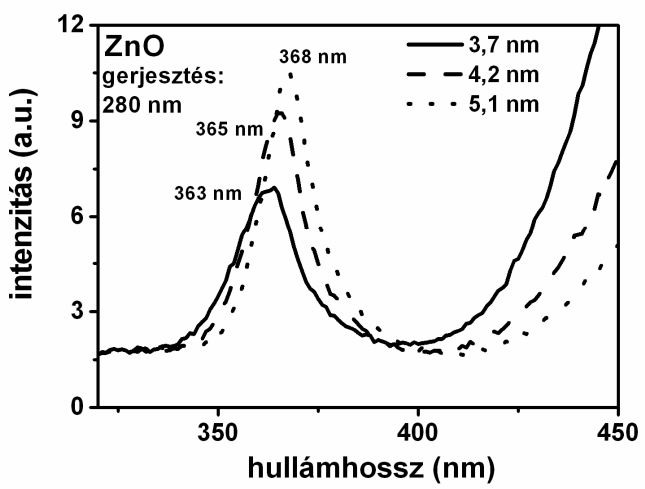

b)

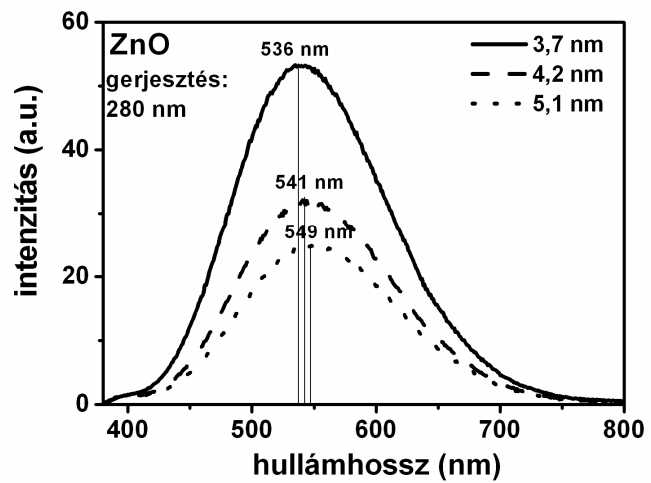

26. ábra. A módosítatlan $\mathrm{ZnO}$ részecskék fluoreszcencia emissziós spektruma a) az UV és a b) látható tartományban 280 nm-es gerjesztő forrás alkalmazásával. 


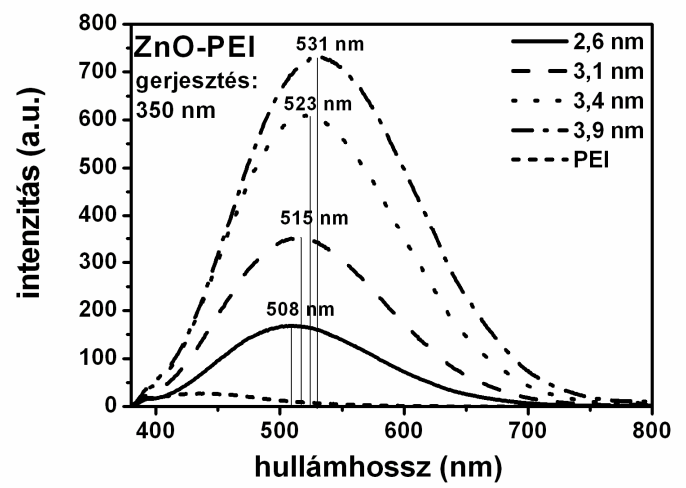

27. ábra. A PEI-vel borított $\mathrm{ZnO}$ részecskék fluoreszcencia emissziós spektruma 350 nm-es gerjesztő forrás alkalmazásával.

A módosítatlan $\mathrm{ZnO}$ részecskék esetében az emissziós spektrumban megjelenik egy gyenge, éles UV csúcs és egy intenzív, széles látható csúcs. A PEI-vel módosított ZnO részecskék esetében csak a látható emisszió jelenik meg, az UV csúcs eltünik. Megállapítható, hogy mind az UV emisszió, mind a látható emisszió mutat méretfüggést, azonban ez az effektus sokkal jelentősebb a látható tartományban.

A látható tartományban jelentkező emissziós csúcsok kiértékelése során meghatároztam az emissziós maximum helyének és intenzitásának változását a részecskeméret függvényében a módosítatlan és a PEI-vel borított $\mathrm{ZnO}$ részecskék esetén három különböző gerjesztési forrás alkalmazásával (28. ábra).

a)

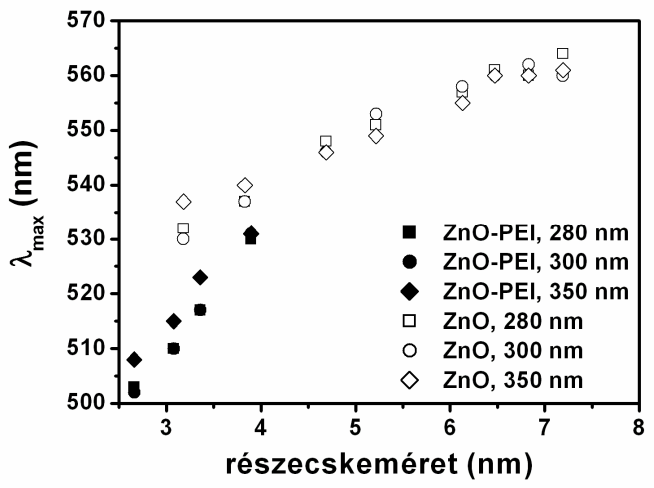

b)

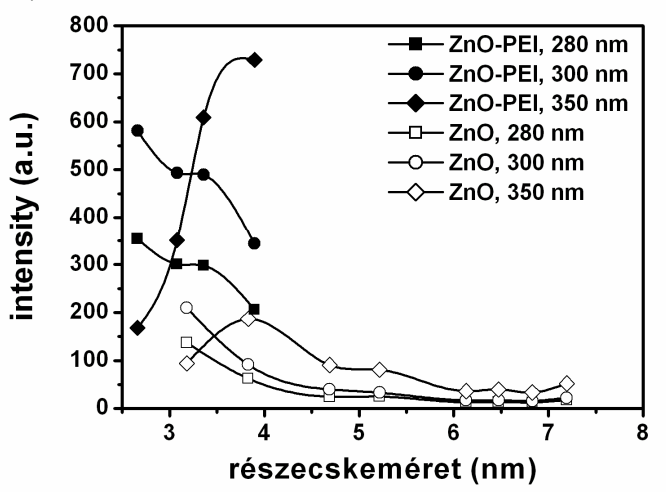

28. ábra. A módosítatlan és a PEI-vel borított $\mathrm{ZnO}$ részecskék emissziós maximuma a) helyének és b) intenzitásának függése a részecskemérettől.

Az emissziós maximum helyének tanulmányozása során megállapítható, hogy a részecskeméret növekedésével a maximum a nagyobb hullámhosszak felé tolódik (,,red shift”) mindhárom gerjesztő forrásnál. Az eltolódás mértéke körülbelül $30 \mathrm{~nm}$ a 


\section{Eredmények I. rész: 48 \\ 3-7 nm-es cink-oxid részecskék és filmjeik}

módosítatlan $\mathrm{ZnO}$ részecskék esetén. Adott átmérő esetén a PEI-vel stabilizált részecskék emissziós maximuma a módosítatlan részecskékhez képest rövidebb hullámhossznál jelentkezik. Az ábráról leolvasható, hogy a vizsgált részecskeméret-tartomány a sima és a PEI-vel borított részecskék esetén eltér egymástól. Ennek oka, hogy a PEI jelenlétében szintetizált részecskék kisebb méretűek lesznek és a stabilizáló hatás miatt nem is nőnek meg akkorára, mint a módosítatlan társaik. Megállapítható továbbá, hogy a gerjesztő forrásnak nincs szignifikáns hatása az emissziós maximum helyére, minimális eltérés van az egyes esetekben.

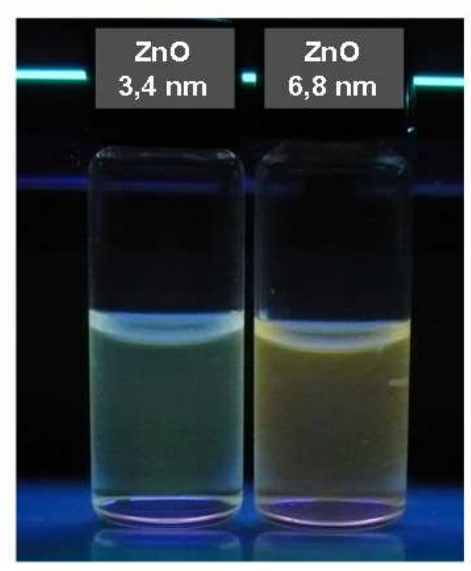

29. ábra. Különböző méretű $\mathrm{ZnO}$ részecskéket tartalmazó szolok emissziójának színe UV lámpa alatt.

Az emisszió intenzitását vizsgálva megállapítható, hogy a PEI-vel borított részecskék jóval intenzívebb emissziót mutatnak. Mindkét típusú részecske (sima és PEI-vel borított) esetén azonos tendencia fedezhető fel a gerjesztő fény hullámhosszával: egy adott átmérőnél nagyobb részecskék esetén a 350 nm-es fényforrás esetén tapasztalható a legintenzívebb emisszió. A 350 nm-es gerjesztő forrás esetében mind a sima, mind a PEI-vel borított $\mathrm{ZnO}$ részecskéknél 3,8 nm-es részecskeméret esetében tapasztalható a legintenzívebb emisszió. Az ennél kisebb részecskéket tartalmazó szolok emissziós intenzitása azért csökken, mert itt a részecskék gerjesztési küszöbenergia értéke már akkora $\left(E_{\mathrm{g}}>3,53 \mathrm{eV}\right.$, ha $\left.\mathrm{d}<3,8 \mathrm{~nm}\right)$, hogy a $350 \mathrm{~nm}$-es forrásnak $\left(\mathrm{E}_{\mathrm{ex}}=3,55 \mathrm{eV}\right)$ nincs akkora energiája, hogy gerjeszteni tudja a részecskéket, csak a szolban kisebb arányban jelen lévő nagyobb méretű frakciók gerjesztése valósítható meg.

A PEI-vel borított $\mathrm{ZnO}$ részecskék esetében mind az emissziós maximum helye, mind az intenzitása változik a módosítatlan részecskékhez képest. A polielektrolit hatásának diszkussziójához a ZnO részecskék emissziójának mechanizmusához kell visszatérni. Amikor a $\mathrm{ZnO}$ részecskékben fény által gerjesztett elektronok képződnek, azok 
relaxációja kétféle, egymással versengő úton valósulhat meg: az excitonok direkt rekombinációja okozza az UV emissziót, a felületi hibahelyeken keresztül történő relaxáció pedig a látható emisszióhoz vezet. PEI hatására megnő a látható emisszió intenzitása, valamint az UV emisszió kioltódik. Ebből következik, hogy a felület beborítása kedvezőtlenül hat a direkt rekombinációs folyamatra, ugyanakkor elősegíti az elektronok felületi hibahelyekhez kötött relaxációját.

\section{V.1.2 Au részecskék}

A vizes közegben szintetizált arany nanorészecskék jellemzésére TEM felvételek készültek (30. ábra a)). A képeken jól látszik, hogy a részecskék gömb alakúak és közel azonos méretủek, ezt jól mutatja a méreteloszlási diagram is (30. ábra b)). A szintézis előnye, hogy szabályos gömb alakú, monodiszperz részecskék nyerhetők vele, valamint a prekurzor $\left(\mathrm{AuCl}_{4}{ }^{-}\right)$és a redukálószer (trinátrium-citrát) mólarányának változtatásával irányítható a képződő részecskék mérete. Munkám során nem volt cél többféle méretü részecskével dolgozni, így nem használtam ki a szintézis ezen lehetőségét.
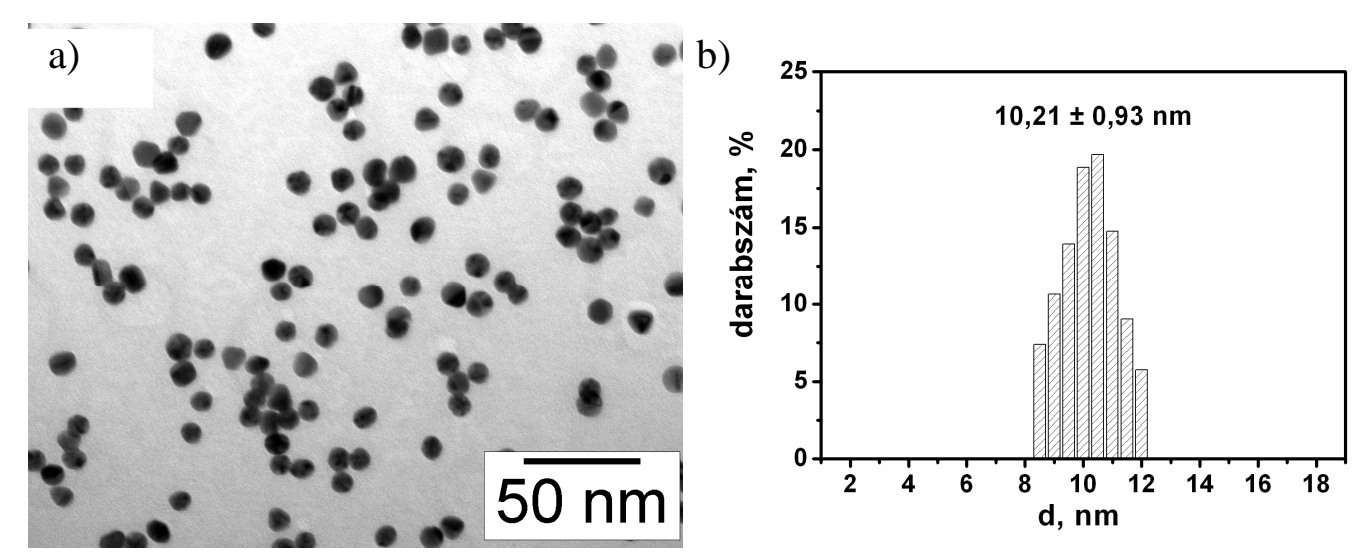

30. ábra. Az Au részecskékről készült TEM felvétel (a) és a jellemző méreteloszlási görbe (b).

$\mathrm{Az}$ arany részecskék plazmonikus tulajdonságainak egyik megnyilvánulása az abszorbancia spektrumban látható erős plazmon elnyelés. Ennek jellemzésére bemutatom $\mathrm{az} \mathrm{Au}$ szol esetében mért jellemző UV-Vis abszorbancia spektrumot (31. ábra). Az 518 nm-nél megjelenő erős elnyelés mutatja, hogy az átlagosan 10 nm-es részecskék izometrikusak és egyedi részecskék vannak a szolban, nincsen aggregáció. Az 518 nm-nél lévő elnyelésnek megfelelően a szol élénk vöröses színü. 


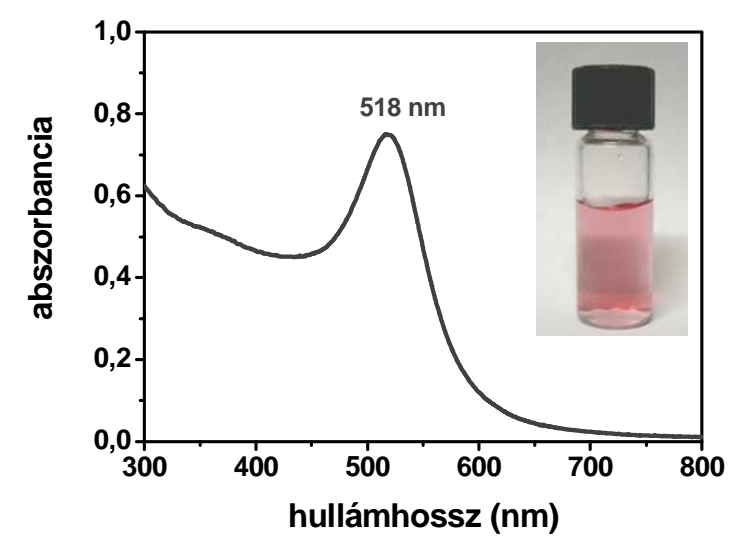

31. ábra. A 10 nm-es Au részecskék szoljának UV-Vis abszorbancia spektruma. A fénykép a szol vöröses színét mutatja be.

\section{V.2 ZnO részecskék vízfelszíni Langmuir-filmjeinek vizsgálata}

A $\mathrm{ZnO}$ részecskék víz/levegő határfelületben kialakított filmeket Langmuirmérlegen tanulmányoztam. A vízfelszínen kialakított Langmuir-filmek kompressziója során regisztráltam az oldalnyomás vs. terület izotermákat, amelyekkel jellemezhető a részecskék felületi tulajdonsága, a film viselkedése. Vizsgáltam a módosítatlan és a PEI-vel borított $\mathrm{ZnO}$ részecskék vízfelszíni filmjeit és alább bemutatok egy-egy jellemző izotermát (32. ábra).

A részecskékből mindkét esetben kialakítható megfelelö vízfelszíni film, amely kompresszióval megfelelő tömörségüre tolható össze, ezáltal szilárd hordozóra vihetők át a Langmuir-Blodgett módszerrel. Az izotermák alapján megállapítottam, hogy a részecskék kohezív filmet képeznek, vonzó jellegủ hidrofób kölcsönhatás lép fel közöttük. Erre utal az is, hogy a mért görbék nem olyan simák, mint a 200-500 nm-es ZnO részecskék esetén mértek (51. ábra): a kompresszió során az összetapadt részecskék szigeteinek rendeződésekor fellépő enyhe törések tapasztalhatók a mért görbén. Látható, hogy a két görbe tendenciájában nem mutat jelentős eltérést, tehát a felületmódosító PEI-nek nincs alapvető módosító hatása a részecskék vízfelszíni viselkedésére. Egyik izotermán sem különíthetők el egyértelműen az egyes fázisoknak megfelelő szakaszok, ami a felületaktív anyagtól mentes nanorészecskés filmeknél általános. 


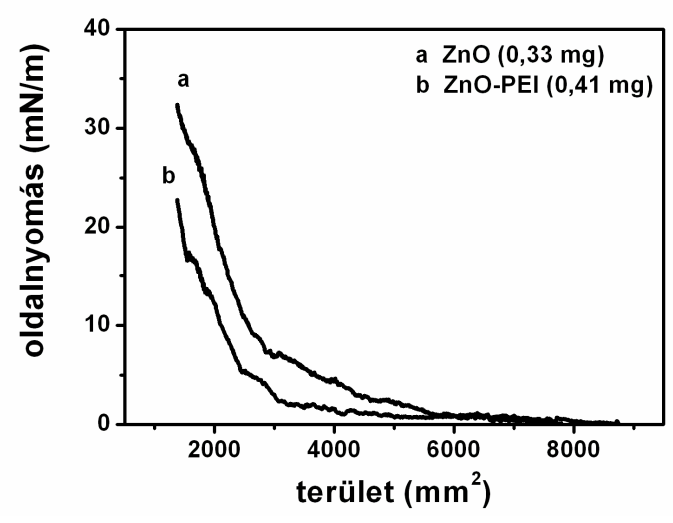

32. ábra. A módosítatlan és a PEI-vel borított $\mathrm{ZnO}$ részecskék víz/levegő határfelületen kialakított filmjeinek oldalnyomás vs. terület izotermái.

A vízfelszínre terített $\mathrm{ZnO}$ mennyiség alapján megállapítható, hogy a PEI-vel borított részecskék esetében több anyagra van szükség a megfelelö tömörségü filmhez. Ez azzal magyarázható, hogy a $\mathrm{ZnO}$ részecskék egy része elhagyja a határfelületet. A folyamat végbemehet a részecskék vízfelszínre terítésekor vagy a részecskék kompressziójakor, illetve mindkét esetben is. A részecskék felületét borító polielektrolit jól oldódik vízben, így az elősegíti a részecskék szubfázisban történő diszpergálását. Mindezek ellenére a PEI-vel borított részecskékből is előállítható megfelelő tömörségü vízfelszíni film, amely alkalmas a szilárd hordozóra történő átvitelre. A filmek szobahőmérsékleten történő száradása után a filmképzési eljárás ismétlésével többrétegű filmek is előállíthatók.

\section{V.3 ZnO részecskék szilárd hordozós Langmuir-Blodgett-filmjeinek tulajdonságai}

A szilárd hordozóra átvitt többrétegü filmeket többféle módszerrel jellemeztem. A filmépítés folyamatát rétegenkénti UV-Vis abszorbancia spektrumok mérésével követtem, az elkészült filmek szerkezetét atomerő mikroszkópos (AFM) technikával jellemeztem. Fluoreszcencia spektrumok mérésével vizsgáltam, hogy hogyan változik meg a részecskék emissziós tulajdonsága a szilárd hordozós filmekben.

Ötrétegü, kvarchordozós filmek építését UV-Vis abszorbancia spektrumok mérésén keresztül követtem, a 33. ábra mutatja a 3,5 nm-es módosítatlan és a 4 nm-es PEI-vel borított $\mathrm{ZnO}$ részecskék esetében felvett spektrumokat. Jól követhető a film 
rétegenkénti épülése, a beillesztett ábra mindkét esetben lineáris összefüggést mutat az abszorbancia és a rétegszám között.

a)

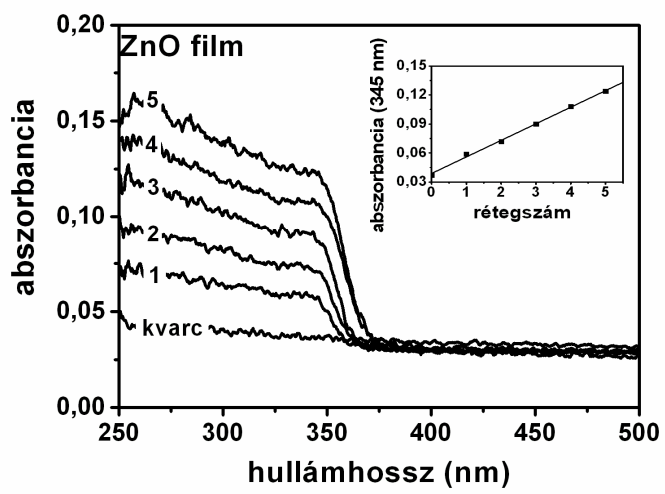

b)

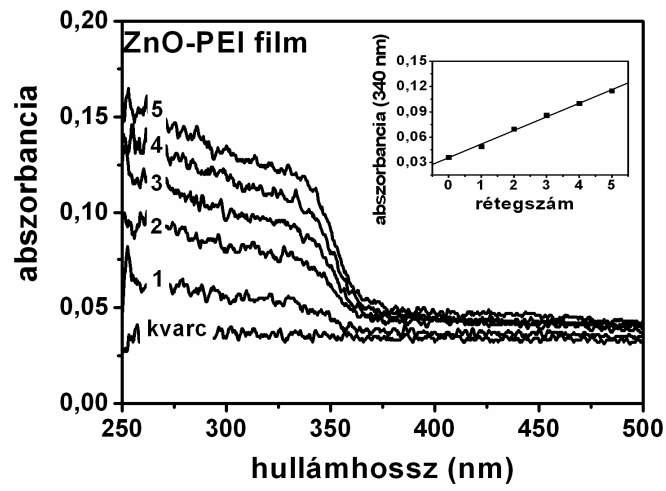

33. ábra. A módosítatlan és a PEI-vel borított $\mathrm{ZnO}$ részecskék 1-5 rétegű Langmuir-Blodgettfilmjeinek UV-Vis abszorbancia spektrumai.

A nanorészecskéket tartalmazó szolok esetében felvettem egy abszorbancia vs. koncentráció kalibrációs egyenest. A 3D-s koncentrációt $\left(\mathrm{mg} / \mathrm{cm}^{3}\right)$ megfeleltettem 2D-s koncentrációnak, azaz fajlagos film tömegnek $\left(\mathrm{mg} / \mathrm{cm}^{2}\right)$, így a film abszorbanciáját leolvasva a kalibrációs görbe felhasználásával meg tudtam határozni a filmek tömegét területegységre vonatkoztatva. Összehasonlításként elméleti úton is kiszámoltam az egységnyi területű, hexagonálisan rendezett monodiszperz részecskék filmjének tömegét figyelembe véve, hogy a film a hordozó mindkét oldalán jelen van, így összesen tehát $2 \times 5$, azaz 10 réteget kellett számításba venni (a számítások részletei a Függelék XI.2 fejezetében). Az eredményeket a 3. táblázat tartalmazza. Látható, hogy a kétféle módon meghatározott értékek megfelelő egyezést mutatnak. A módosítatlan és a PEI-vel borított $\mathrm{ZnO}$ részecskék filmjeinek elméleti tömegértékei azért nem egyeznek meg, mert eltérő méretü részecskék alkotják a filmet, így a film vastagsága és ezáltal a tömege is különböző lesz.

3. táblázat. A módosítatlan és a PEI-vel borított $\mathrm{ZnO}$ részecskés filmek fajlagos tömegének meghatározása kétféle módszerrel.

\begin{tabular}{lcc}
\hline & $\begin{array}{c}\mathrm{ZnO} \text { film tömeg } \\
\left(\boldsymbol{\mu g} / \mathrm{cm}^{2}\right)\end{array}$ & $\begin{array}{c}\mathrm{ZnO}-\mathrm{PEI} \text { film tömeg } \\
\left(\boldsymbol{\mu g} / \mathrm{cm}^{2}\right)\end{array}$ \\
\hline $\begin{array}{l}\text { Kalibrációs } \\
\text { módszer }\end{array}$ & 9,7 & 8,5 \\
$\begin{array}{l}\text { Elméleti } \\
\text { számítás }\end{array}$ & 8,0 & 9,0 \\
\hline
\end{tabular}




\section{Eredmények I. rész: 53 \\ 3-7 nm-es cink-oxid részecskék és filmjeik}

A többrétegü, üveghordozóra felépített filmek szerkezetét atomerő mikroszkópos (AFM) technikával jellemeztem. A 34. ábra mutatja a 3,8 nm-es $\mathrm{ZnO}$ részecskékből, valamint a 4,0 nm-es PEI-vel borított $\mathrm{ZnO}$ részecskékből épített 5 rétegü film AFM képét. A tapogató tủ felbontóképességének korlátja miatt a kisméretű részecskék nem különíthetők el individuálisan a képeken, az egymáshoz közel fekvő részecskék a képen egy nagyobb részecskének látszanak. A két képet összehasonlítva megállapítható, hogy a PEI-vel borított részecskékből egyenletesebb film építhető, kevesebb a hiba a film szerkezetében.
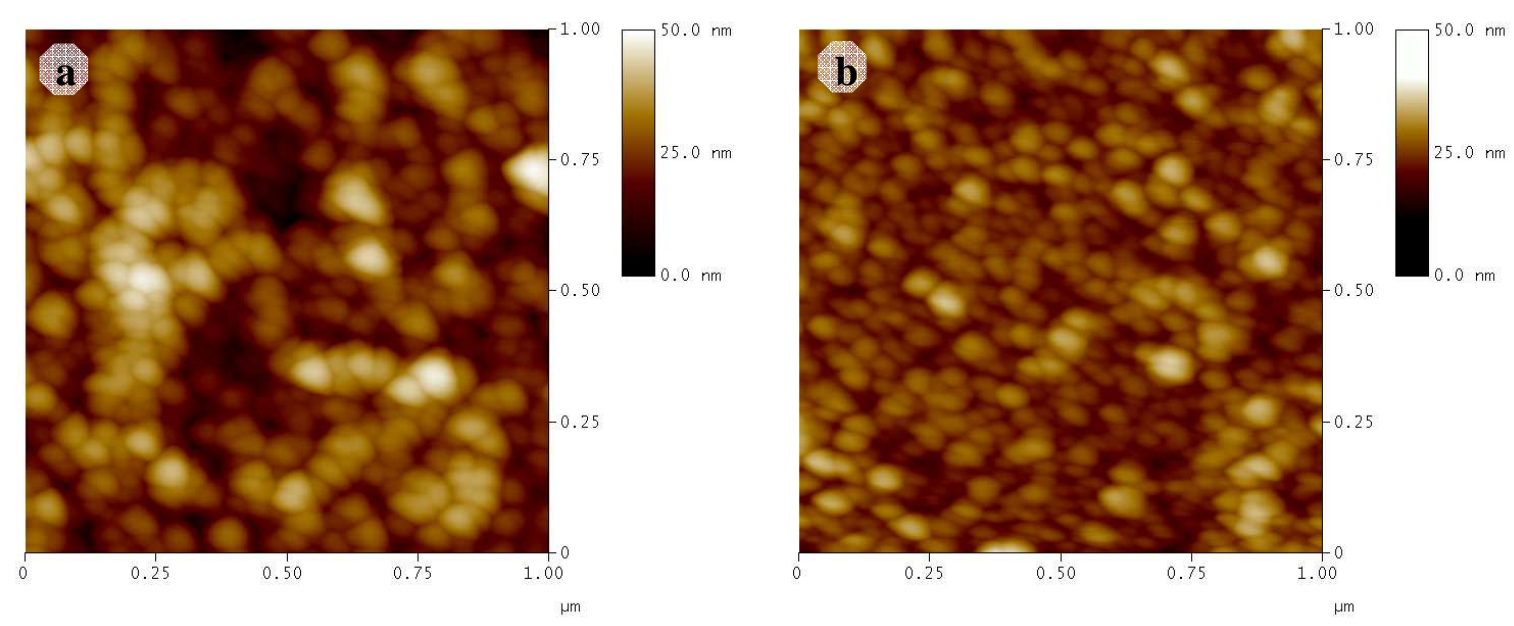

34. ábra. A módosítatlan (a) és a PEI-vel borított (b) ZnO részecskék 5 rétegü Langmuir-Blodgettfilmjeinek AFM képei.

Fluoreszcencia emissziós méréseket végeztem a $\mathrm{ZnO}$ részecskékből kvarchordozóra felépített egy és többrétegü filmjein a részecskék filmbeli emissziós sajátságainak jellemzésére. A 35. ábra mutatja a módosítatlan és a PEI-vel borított részecskék 1-5 rétegü filmjeinek emissziós spektrumait $350 \mathrm{~nm}$ gerjesztési forrással, a 36. ábra pedig az 5 rétegü filmek emisszióját három különböző gerjesztő forrás $(280,300$ és $350 \mathrm{~nm}$ ) esetén.

A ZnO és a PEI-vel módosított $\mathrm{ZnO}$ részecskék 1-5 rétegü filmjeinek spektrumai azt mutatják, hogy már 1 rétegben felvitt film is jelentős fluoreszcencia emissziót mutat, a további rétegszám növeléssel már csak kismértékben erősödik az emisszió a ZnO mennyiség növekedésének következtében. 
a)

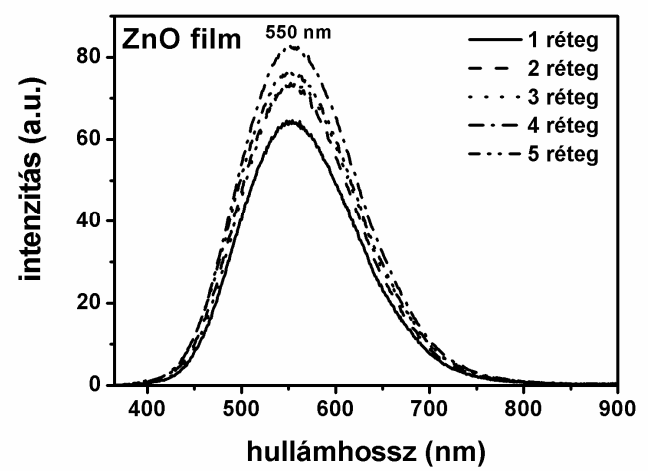

b)

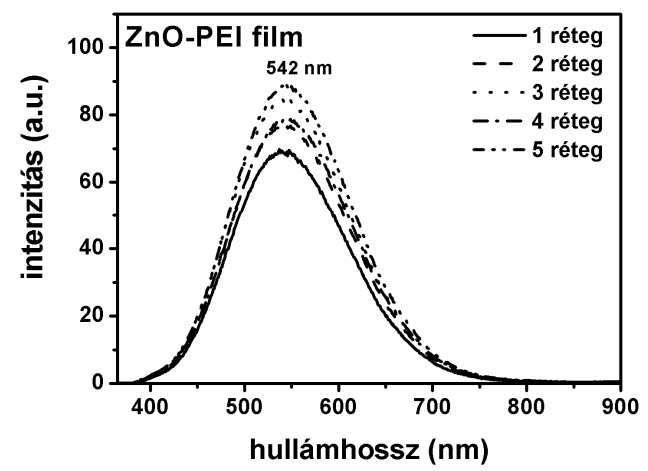

35. ábra. A módosítatlan és a PEI-vel borított $\mathrm{ZnO}$ részecskék 1-5 rétegü filmjeinek fluoreszcencia emissziós spektruma.

a)

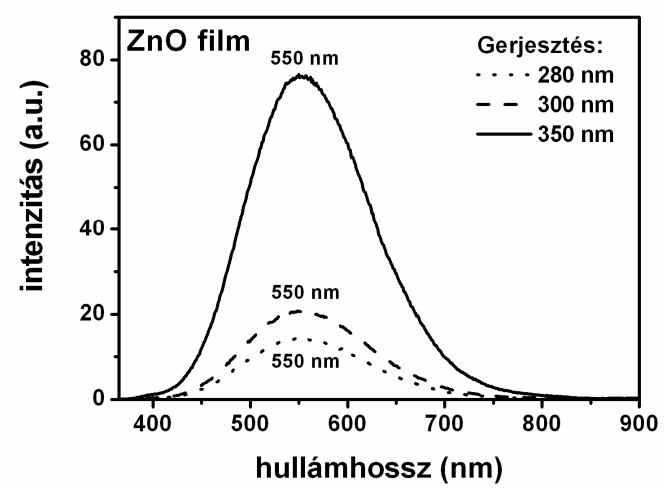

b)

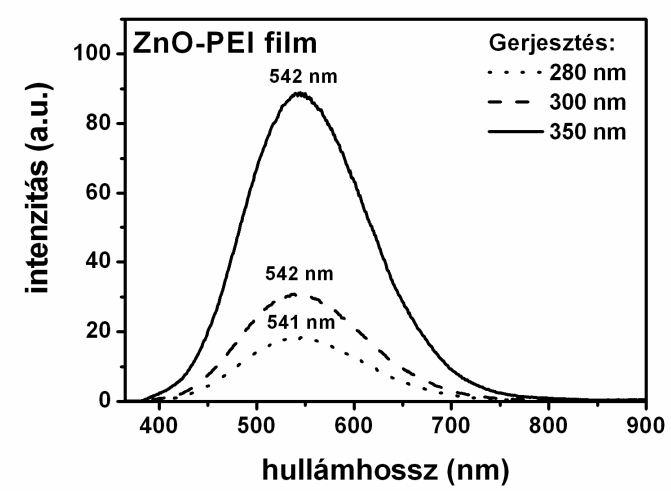

36. ábra. A módosítatlan és a PEI-vel borított $\mathrm{ZnO}$ részecskék 5 rétegü filmjeinek fluoreszcencia emissziós spektrumai különböző gerjesztési hullámhosszak mellett.

A 4,6 nm-es módosítatlan részecskék filmjének mindhárom gerjesztési forrás esetén 550 nm-nél van emissziós maximuma. A 4,6 nm-es részecskék etanolos közegü szoljainak emissziós maximuma gerjesztési forrástól függően 545-547 nm között jelentkezett, tehát a részecskék emissziója a filmben 3-5 nm-t tolódott, de az emisszió megmaradt. A filmek esetében az UV tartományban lévő emisszió teljesen kioltódott. A 4 nm-es PEI-vel borított részecskék filmje 541-542 nm-nél emittál (gerjesztési hullámhossztól függően), míg ugyanezen részecskék szoljainak emissziós maximuma 531-532 nm-nél található (28. ábra), ami egy jelentősebb eltérés. Figyelembe véve, hogy a 4 nm-es, módosítatlan részecskéknek 538-541 nm-nél jelentkezik emissziós maximuma, arra a következtetésre lehet jutni, hogy a polielektrolittal borított részecskékből épített filmben már nem, vagy csak kis mennyiségben található meg a felületmódosító anyag. Feltételezhető, hogy a filmépítés 
folyamata során a vízfelszínre felvitt filmből a polielektrolit egy jelentős része a szubfázisban való jó oldhatósága miatt elhagyja a határfelületet, valószínüleg magával ragadva a $\mathrm{ZnO}$ részecskék bizonyos hányadát. Ezt alátámasztja az a korábbi megállapítás, hogy a módosítatlan és a PEI-vel borított részecskék oldalnyomás-terület izotermái nagyon hasonlóak. A szilárd hordozóra átvitt nanorészecskés film tehát feltehetően a csökkent polielektrolit tartalma miatt a módosítatlan részecskékhez hasonlóan viselkedik.

Megállapítható tehát, hogy a $\mathrm{ZnO}$ részecskék megőrzik látható emissziójukat a filmben, azonban az etanolos közegü szolban mérhető UV emisszió a filmekben kioltódik. A részecskék méretének változtatásával változtatható a filmek emissziós maximumának helye, ezáltal hangolható emissziójú filmek előállítására van lehetőség.

\section{V.4 Au és ZnO tartalmú hibrid filmek}

\section{V.4.1 Aranybevonatú hordozók jellemzése}

$\mathrm{Az}$ arany és a $\mathrm{ZnO}$ plazmonikus kölcsönhatásának jellemzésére arannyal bevont hordozóra építettem fel a $\mathrm{ZnO}$ részecskék Langmuir-Blodgett-filmjeit. Ezekhez a vizsgálatokhoz kétféle arannyal bevont hordozót használtam: spray coating technikával, 10 $\mathrm{nm} \mathrm{Au}$ részecskékkel bevont kvarclapot, illetve $50 \mathrm{~nm}$ vastagságú folytonos Au filmmel borított üveglapot. A kétféle aranybevonat szekeztét AFM technikával készített képek segítségével hasonlítottam össze.

A $10 \mathrm{~nm}$-es $\mathrm{Au}$ részecskék filmjéről készült képen (37. ábra) látható, hogy a hordozó nagyjából egyenletesen borított a részecskékkel, de nem alakult ki folytonos réteg. A hordozón egyedi részecskék találhatók, amelyek egymás közelében helyezkednek el, de nincsenek a felületen aggregált részecske halmok. A képen négy nagyobb méretü, feketével színezett mélyedés látható a hordozón, ezek az üveghordozó hőkezelése során keletkezett üregek. Ahogyan korábban részleteztem (IV.3.1. alfejezet), technikai okok miatt az AFM mérésekhez a filmeket kvarc helyett üveglapokra készítettem el. A minták azonos kezelése végett az üveghordozós minták hőkezelését is fontosnak tartottam, ennek következtében alakultak ki a képen látható üregek.

A filmen az egyedi részecskék jelenlétét mutatja a kép keresztmetszeti analízise is: nagyjából $10 \mathrm{~nm}$-es, egyedi részecskéket mutatnak a görbék. A piros pontozott vonallal megjelölt területen (a hordozó hibahelyeit kihagyva) felületi érdességet számítottam a (11) egyenlet segítségével, melynek eredménye 4,89 nm. 

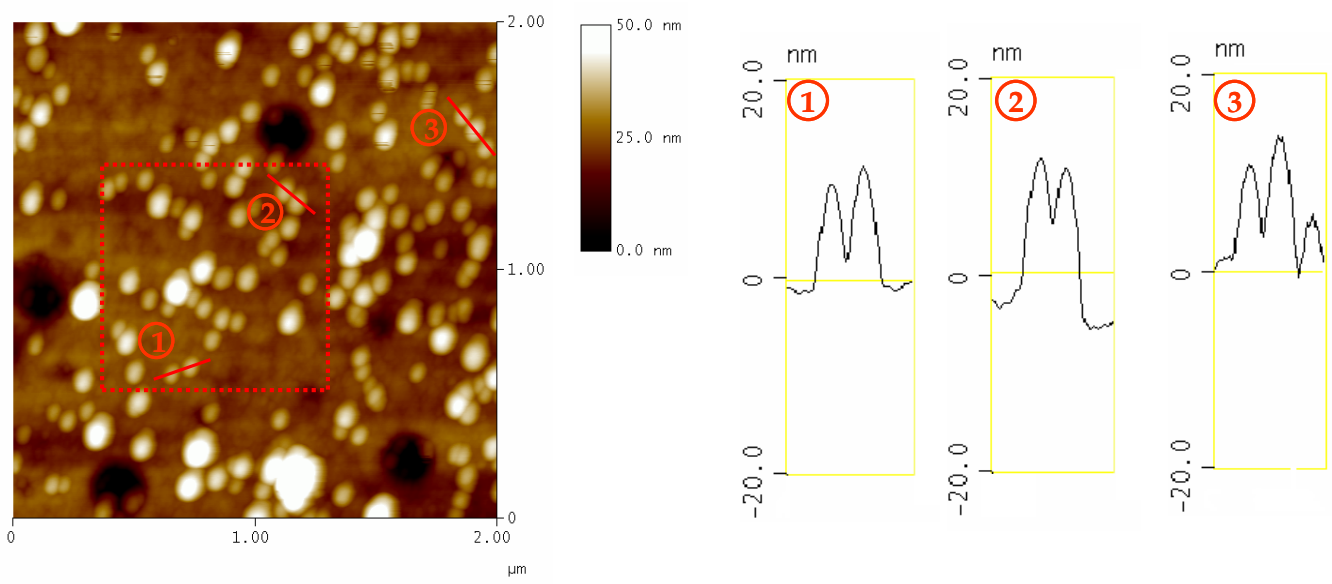

37. ábra. A $10 \mathrm{~nm}$-es Au részecskék filmjéről készült AFM topográfiai kép és a keresztmetszeti analízis.

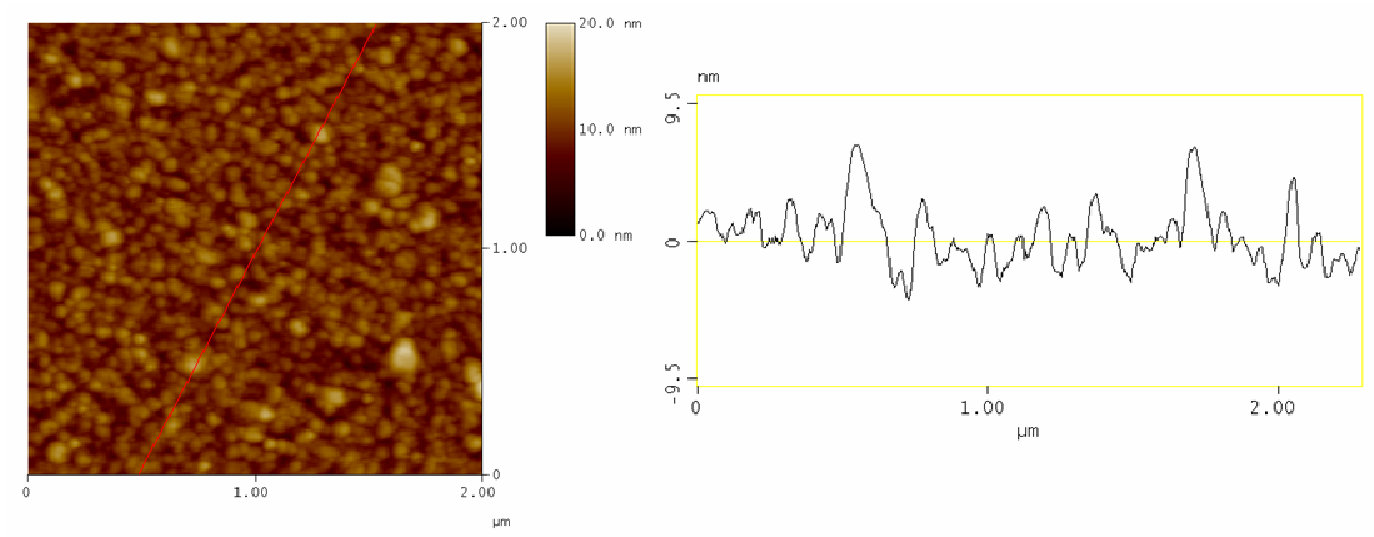

38. ábra. Az $50 \mathrm{~nm}$ vastag folytonos Au réteg AFM topográfiai képe és keresztmetszeti analízise.

$\mathrm{Az} 50 \mathrm{~nm}$ vastag folytonos arany filmmel bevont hordozó felületéröl egy reprezentatív képet mutat a 38. ábra. Látható, hogy a film folytonos, egyenletesen beborítja a hordozót, valamint megállapítható az is, hogy a felszíne szemcsés jellegü. A keresztmetszeti kiértékelés is ezeket a megállapításokat támasztja alá. Ennél a mintánál is meghatároztam a felület érdességet, amely 1,78 nm-nek adódott, amely egy viszonylag sík felszínre jellemző érték.

\section{V.4.2 Au-ZnO hibrid filmek tulajdonságai}

A 10 nm-es Au részecskék kvarchordozós filmjeit UV-Vis abszorbancia spektrumokkal jellemeztem (39. ábra). A grafikonon látható az arany részecskék, illetve a $\mathrm{ZnO}$ észecskék Langmuir-Blodgett rétegével bevont Au részecskék filmjeinek spektruma. 
A vizes közegben mért 518 nm-es abszorpciós sáv (31. ábra) a filmek esetében 548 nm-re tolódott el. Ennek oka, hogy megváltozott a részecskék körüli lokális környezet. Egyrészt bizonyos helyeken a részecskék közötti távolság jóval kisebb lehet, mint a vizes közegü szolban, így a részecskék közötti kölcsönhatások szerepet játszhatnak a plazmonikus elnyelés energiájának módosításában. Másrészt a kvarchordozó releváns paraméterei (törésmutató és egyéb optikai jellemzők) is jelentősen eltérnek a vízétől, amely a részecskék körüli lokális elektromos teret befolyásolja.

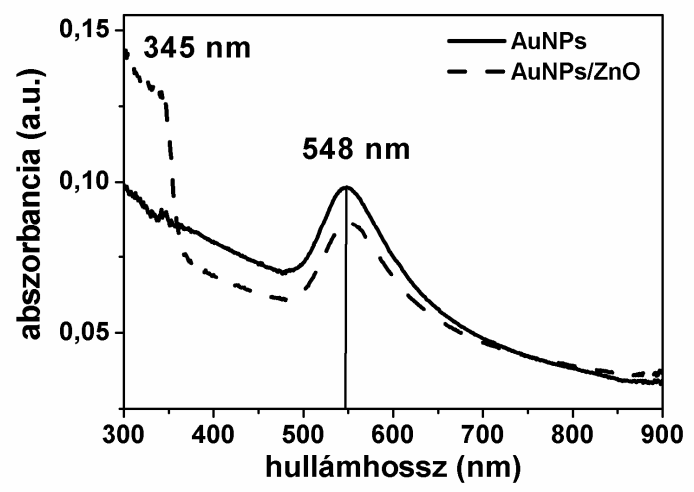

39. ábra. A $10 \mathrm{~nm}$-es Au részecskék kvarchordozós filmjeinek UV-Vis abszorbancia spektrumai.

$\mathrm{Az} \mathrm{Au}-\mathrm{ZnO}$ hibrid film spektrumán a $\mathrm{ZnO}$ részecskék elnyelési sávja 345 nm-nél látható, amely jó egyezésben van a csak $\mathrm{ZnO}$ részecskékből álló film esetében kapott eredményekkel (33. ábra). Az 50 nm-es arannyal bevont filmek esetében a spektrumok nem mérhetőek, ugyanis a film transzmittanciája nagyon kicsi.

A sztearinsavból készített Langmuir-Blodgett rétegeket távtartó funkció miatt vittem fel a $\mathrm{ZnO}$ és az Au közé. Ezeknek a rétegeknek a minősítésére röntgendiffrakciós méréseket végeztem. A sztearinsav rendezett, réteges szerkezetére jellemző reflexiók alacsony szögtartományban jelentek meg, ahogyan az az AuF/SA(6)/ZnO jelü minta diffraktogramján jól látszik (40. ábra). Az elsőrendű reflexió $\left(\mathrm{d}_{001}\right)$ mellett határozott, éles csúcsokként jelennek meg a másod- és magasabb rendủ reflexiók $\left(\mathrm{d}_{002}-\mathrm{d}_{005}\right)$. Az egyes reflexiók a 2,02, 4,08, 6,18, 8,24 és 10,3 $2 \theta$ szögeknél jelentkeznek, amelyek rendben 43,7, 21,64, 14,3, 10,72 és 8,58 Å rácstávolságoknak felelnek meg. Ezekből visszaszámolva, az öt reflexió esetén kapott eredményeket átlagolva egy sztearinsav réteg vastagságára 4,4 nm-t kaptam. 


\section{Eredmények I. rész: 58 \\ 3-7 nm-es cink-oxid részecskék és filmjeik}

A sztearinsav molekula hossza jó közelítéssel meghatározható az alábbi egyszerü képlettel:

$$
L=0,127 \cdot\left(n_{c}-1\right)+0,1+0,24,
$$

ahol $\mathrm{n}_{\mathrm{c}}$ a molekulát alkotó $\mathrm{C}$ atomok száma (sztearinsav esetén $\mathrm{n}_{\mathrm{c}}=18$ ), 1,27 megfelel egy zig-zag konformációban lévő C-C kötés hosszának a molekula hossztengelyére vetítve nm-ben kifejezve, 0,1 a C-H kötés, 0,24 pedig a C-O-H csoport hossza szintén nm-ben kifejezve [141]. Ez alapján a sztearinsav molekula hosszára L=2,5 nm adódik, ami jó egyezést mutat korábbi irodalmi adatokkal [141].

Ha összevetjük a röntgendiffrakciós mérésekböl meghatározott rácstávolságot egyetlen sztearinsav molekula hosszával, akkor látható, hogy ez az eredmény csak úgy képzelhető el reálisan, ha ez egy kettősréteget jellemez. A kísérletek részletezése során kitértem rá, hogy a többrétegű sztearinsav filmeket a $\mathrm{Z}$ típusú depozíciós módon készítettem. Ezeknél a filmeknél a szomszédos rétegek molekulái fej-lánc érintkezésben vannak, ami termodinamikailag kevésbé stabil filmet jelent.

a)

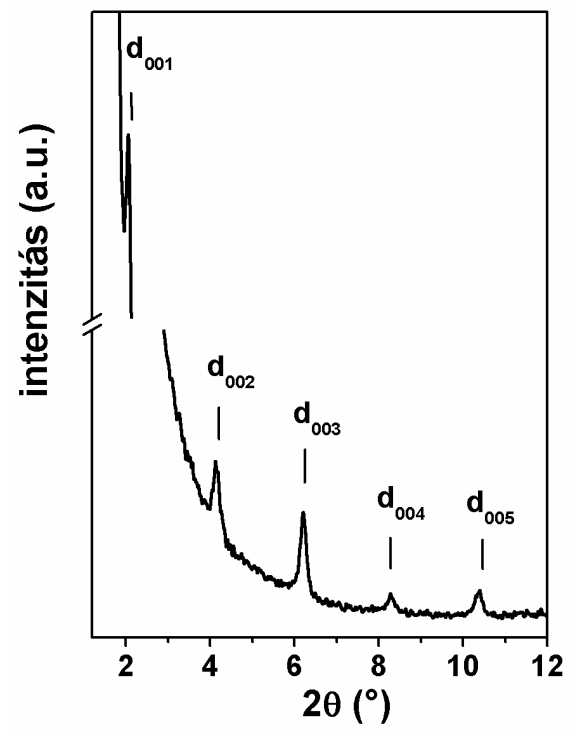

b)

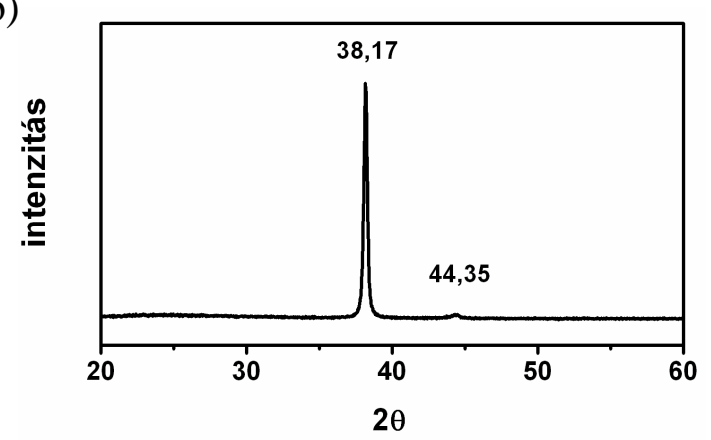

c)
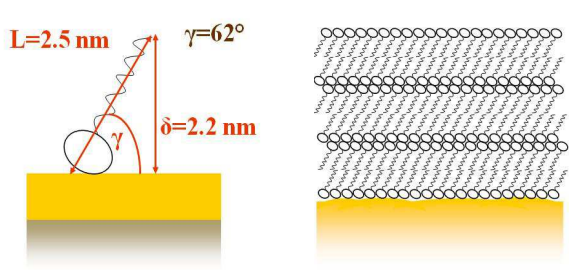

40. ábra. A AuF/SA(6)/ZnO jelü film XRD diffraktogramja az (a) 1-20 illetve a (b) 20-60 $2 \Theta$ szögtartományban; (c) a sztearinsav molekulák feltételezett elrendeződése a többrétegű filmben.

Az irodalomban található több példa olyan munkára, ahol a szerzők kimutatták, hogy a Z típusú depozícióval készített, már szilárd hozdozón lévő rétegek molekulái megváltoztathatják orientációjukat és a termodinamikailag stabilabb, fej-fej érintkezésben rendeződnek el. Ez az átrendeződés végbemehet egyrészt egy újabb réteg leválasztása során a vizes szubfázisba merített filmben vagy akár levegőn is. Ezek alapján egyetlen 


\section{Eredmények I. rész: 59 \\ 3-7 nm-es cink-oxid részecskék és filmjeik}

sztearinsav réteg vastagságát az XRD mérésekből kapott érték fele jellemzi, azaz $\delta=2,2$ $\mathrm{nm}$.

A sztearinsav réteg vastagsága tehát $2,2 \mathrm{~nm}$, ami rövidebb, mint egyetlen molekula hossza. Ez úgy képzelhető el, hogy a molekula hossztengelye nem merőleges a film síkjára, hanem valamekkora szöget zár be azzal, ahogyan azt a 40. ábra c) része szemlélteti. A szinusz függvény definíciója alapján egyszerủen kiszámítható ez a szög, amely jelen esetben $\gamma=62^{\circ}$-nak adódott. Ezek alapján a többrétegü film szerkezete a 40. ábra d) része szerint képzelhető el.

Ezek alapján a többrétegü sztearinsav LB-filmek vastagsága jó közelítéssel $\delta=2,2 \mathrm{~nm}$ egész számú többszöröseivel jellemezhetők, tehát az $\mathrm{Au}$ és a $\mathrm{ZnO}$ közötti távolság is ezen diszkrét értékek között változtathatók ezzel a módszerrel.

$\mathrm{Az}$ AuF/SA(6)/ZnO jelü mintáról a 20 - 6020 szögtartományban készült diffraktogramot a 40. ábra b) része mutatja. Ebben a tartományban egy nagy intenzitású, éles csúcs jelenik meg $38,17^{\circ}$-nál, valamint egy gyenge reflexió $44,35^{\circ}$-nál, amelyek az Au filmtől származnak. A $\mathrm{ZnO}$ részecskékre jellemző 3 intenzív csúcs a 30 - $40^{\circ}$ tartományban található, de ezek nem láthatók a görbén, feltehetően a kis anyagmennyiség miatt.

A $\mathrm{ZnO}$ és $\mathrm{Au}$ tartalmú hibrid filmek készítésével célom volt, az $\mathrm{Au}$ és a $\mathrm{ZnO}$ közötti plazmonikus kölcsönhatás jellemzése fluoreszcencia emissziós mérésekkel. Tanulmányozni kívántam a kölcsönhatás távolságfüggését (az Au és a $\mathrm{ZnO}$ közé beékelt sztearinsavból álló távtartó rétegek) valamint az Au struktúrájának hatását (nanorészecskék vagy folytonos film). Ezekhez a mérésekhez készült, kétféle sorozatba tartozó mintákat a IV.3.2. alfejezetben mutattam be.

A $10 \mathrm{~nm}$-es Au részecskék sorozata esetében az UV és a látható tartományban mért fluoreszcencia emissziós spektrumokat mutatja a 41. ábra. A spektrumokon látható, hogy mind a látható, mind az UV tartományban lévő emisszió esetében erősítés mérhető az Au részecskék jelenlétének köszönhetően. Megállapítható, hogy az erősítés távolságfüggő: a legerősebb emisszió ezen sorozat elemei közül a csak Au-t és ZnO-t tartalmazó filmeknél mérhető, vagyis amikor nincsen távtartó közöttük. Az emisszió paramétereinek ZnO-Au távolságfüggő értékelését a 43. ábra diagramjai szemléltetik (az UV emisszió meglehetősen gyenge, az emissziós csúcsok értékelése meglehetősen nagy hibával terhelt lenne, ezért az ezekkel való kvalitatív számolásokat elvetettem). Látható, hogy ennél a sorozatnál 
kismértékű eltolódás (3 nm) és valamivel több, mint kétszeres erősítés érhető el. Érdekes megjegyezni, hogy ez a két effektus különböző minták esetén figyelhető meg.

a)

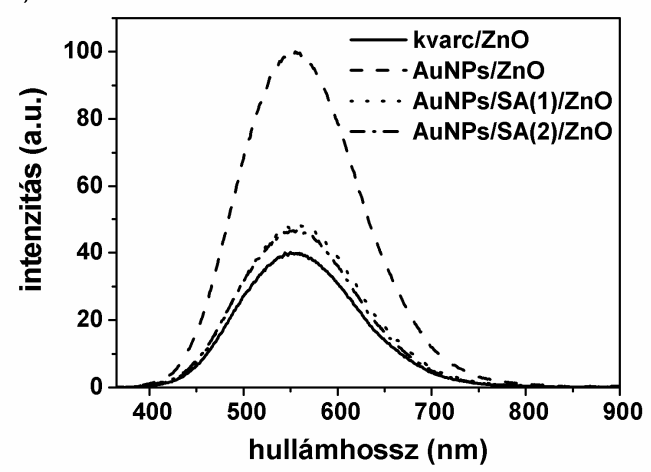

b)

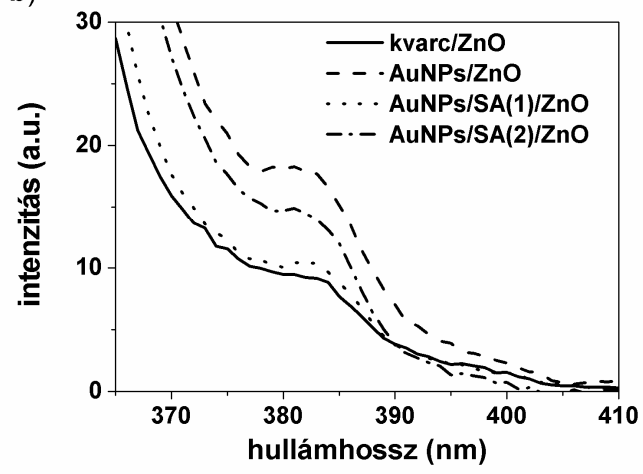

41. ábra. A $10 \mathrm{~nm}$-es Au nanorészecskés filmek sorozata esetén mért fluoreszcencia emissziós spektrumok a) a látható és b) az UV tartományban (gerjesztés: $350 \mathrm{~nm}$ ).

$\mathrm{Az} 50 \mathrm{~nm}$ vastagságú, folytonos $\mathrm{Au}$ film sorozata esetén mért látható és UV tartománybeli emissziós spektrumokat a 42. ábra mutatja be. Ennél a sorozatnál is megállapítható, hogy az Au jelenlétének köszönhetően jelentős intenzitásnövekedés mérhető az UV és a látható emisszió esetében is. Az emissziós jellemzők $\mathrm{Au}-\mathrm{ZnO}$ távolságfüggését a 43. ábra grafikonjai szemléltetik. Az emissziós maximum eltolódása maximum típusú függést mutat: a legnagyobb, 7 nm-es eltolódás 4,4 nm-nél, azaz 2 réteg sztearinsav távtartó esetén mérhető. Érdekes megjegyezni, hogy abban az esetben, amikor a $\mathrm{ZnO}$ és az Au közvetlen kapcsolatban vannak, az emisszió a kisebb hullámhosszak felé tolódik el 2 nm-el.
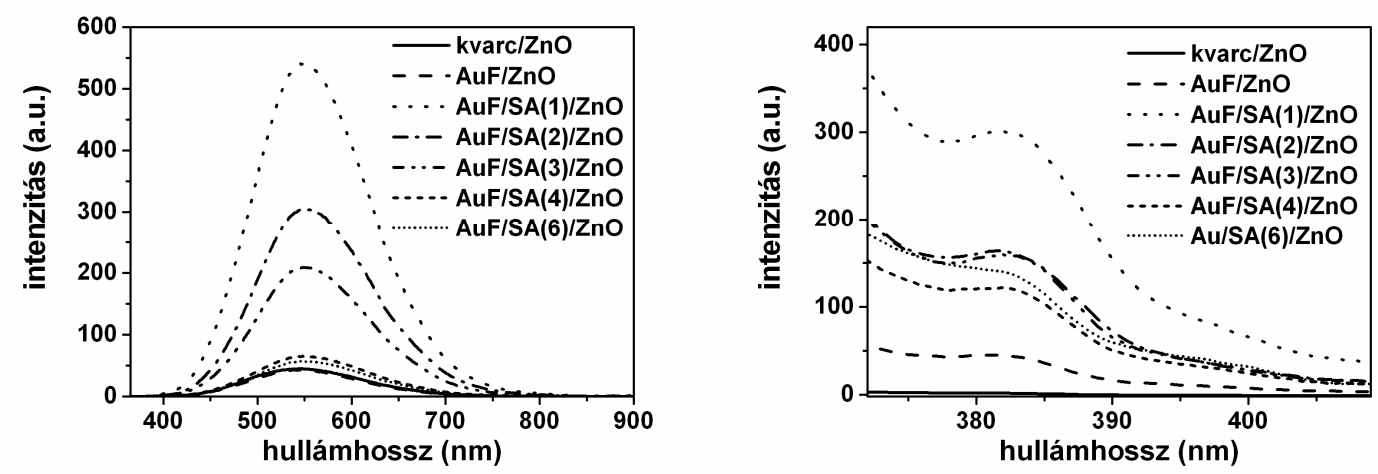

42. ábra. Az $50 \mathrm{~nm}$ vastagságú folytonos Au film sorozat tagjainak fluoreszcencia emissziós spektruma a) a látható és b) az UV tartományban. 
$\mathrm{Az}$ emissziós intenzitást elemezve megállapítható, hogy távtartó nélkül gyakorlatilag megegyezik az emisszió intenzitása a csak ZnO-ot tartalmazó mintánál mért intenzitással. Azonban igen jelentős, 12-szeres intenzitáserősödés érhető el 2,2 nm Au-ZnO távolság esetén, azaz 1 sztearinsav távtartó réteggel. A távtartó rétegek számának további növelésével az erősítés közel exponenciálisan csökken, 6 réteg esetén pedig az emisszió erőssége gyakorlatilag megegyezik a ZnO film esetén mért értékkel.
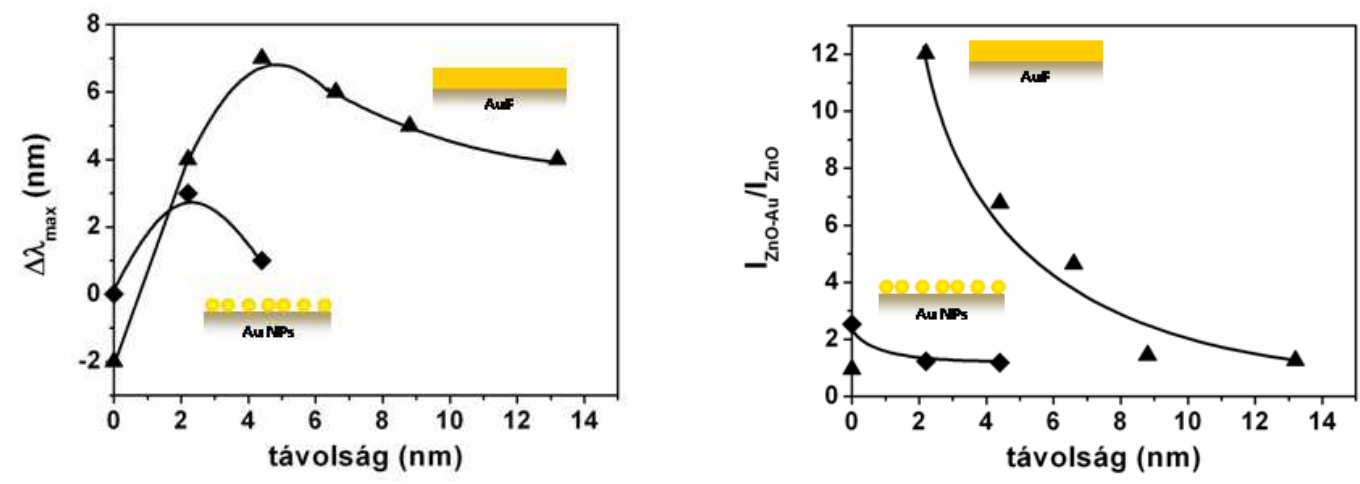

43. ábra. Az Au-ZnO hibrid filmek esetén mért floureszcencia emissziós a) eltolódás és b) erősítés a $\mathrm{ZnO}$-Au távolság függvényében.

A kísérleti eredmények a $\mathrm{ZnO}$ részecskék emissziójának szignifikáns erősítését mutatják arany közelében. Jelentős különbség mutatkozik azonban a 10 nm-es Au részecskék filmjének és az $50 \mathrm{~nm}$-es folytonos $\mathrm{Au}$ film hatásában: a vastag arany film közelében sokkal intenzívebb az erősítés és nagyobb a maximális eltolódás is. Ennek azonban több oka lehet: különböző Au mennyiség a filmben (a nanorészecskék filmje sokkal kisebb mennyiségü aranyat tartalmaz egységnyi területen) vagy a filmek és részecskék eltérő plazmon rezonancia tulajdonságai. Nem egyértelmü viszont az, hogy az Au mennyiségének növelésével erősödik az emisszió. Im és munkatársai [89] ZnO rudak felületére kapcsoltak Au részecskéket és arra az eredményre jutottak, hogy növekvő borítottság mellett csökken az emissziós intenzitás. Tehát önmagában az, hogy a részecskés filmekben kisebb az Au mennyisége biztosan nem lehet magyarázat az eltérő viselkedésre, a kölcsönhatás ennél bonyolultabb

$\mathrm{Az} \mathrm{Au}$ részecskékre jellemző lokális plazmon rezoncia a közeli térben lejátszódó kölcsönhatásokkal gerjeszthető. A gerjesztett állapotú $\mathrm{ZnO}$ részecskék oszcilláló dipólként viselkednek, amelyek képesek az Au részecskék plazmon rezonanciát létrehozni. A részecskék plazmon rezonanciája következtében megerősödött lokális elektromos erőtér képes befolyásolni a $\mathrm{ZnO}$ részecskék emissziós tulajdonságait [96, 142]. Ez a dipól 
kölcsönhatásokon alapuló folyamat a fém által erősített emisszió (metal enhanced fluorescence), amely magyarázza az $\mathrm{Au}$ részecskés sorozat tagjai esetén kapott eredményeket. A részecskék lokalizált felületi plazmon rezonanciája sokkal rövidebb hatótávolságú, mint a folytonos filmeké, így ezeknél a mintáknál akkor tapasztalható a legnagyobb erösítés, ha közvetlen kapcsolatban van az $\mathrm{Au}$ a $\mathrm{ZnO}$-dal, azaz nincsen közöttük távtartó.

Amikor egy nemesfém folytonos filmjét gerjesztjük, felületi plazmon polaritonok keletkeznek, amelyek képesek a fém/dielektrikum határfelületén terjedni. Ezek a terjedő plazmon polaritonok létrehoznak egy elektromos erőteret, az evaneszcens teret, amely hatással van a ZnO emissziójára Purcell-erősítés vagy dipól kölcsönhatás által. Ez a mechanizmus érvényes az $50 \mathrm{~nm}$ vastag Au filmet tartalmazó minták esetében, amikor távtartó van az $\mathrm{Au}$ és a $\mathrm{ZnO}$ között. Erre utal az is, hogy az erősítés exponenciális csökkenése a távolsággal összhangban van az evaneszcens tér exponenciális lecsengésével. Korábbi kísérletek során kimutatták, hogy a $\mathrm{ZnO}$ és $\mathrm{Au}$ közvetlen érintkezése esetén töltésátvitel történik, amely az UV emisszió erősítéséhez és a látható emisszió csökkenéséhez vezet $[87,88,143]$. Az AuF/ZnO jelü minta esetén (nincs távtartó) valószínüsíthető a töltésátvitel lejátszódása a ZnO-ról a fémre, amely magyarázza a látható emisszió enyhe csökkenését és az UV emisszió erősödését. Ezt a mechanizmust erősíti továbbá az az érv is, hogy a töltésátviteli folyamat Fermi-szint kiegyenlítődéssel is jár, amely viszont a gerjesztési küszöbenergia növekedéséhez, ezáltal az emisszió kék eltolódásához vezet [24, 39]. Ez a jelenség meg is figyelhető az AuF/ZnO minta esetén (43. ábra). Valószínüsíthető továbbá, hogy a töltésátviteli folyamat nélkül az emisszió intenzitását az $\mathrm{Au}$ körüli elektromos erőtér határozná meg, így viszont jóval erősebb emisszió lenne várható.

Az Au és ZnO-t tartalmazó hibrid filmek fluoreszcencia emissziós méréseivel rámutattam, hogy a fém és a $\mathrm{ZnO}$ között létrejön egy plazmonikus kölcsönhatás, amely jelentős hatással lehet a $\mathrm{ZnO}$ emissziójára. A ZnO és az Au távolságának, valamint az $\mathrm{Au}$ morfológiájának, szerkezetének is meghatározó szerepe van a kölcsönhatás alakulásában, ezáltal az emisszióra való hatásában is. Az 50 nm vastagságú, folytonos Au filmek esetén egy sztearinsav távtartó réteg esetében jelentős, közel 12-szeres intenzitás növekedést tapasztaltam. 


\section{EREDMÉNYEK II. RÉSZ 200-500 NM-ES CINK-OXID RÉSZECSKÉK ÉS FILMJEIK}

Ebben a fejezetben bemutatom a 200-500 nm mérettartományban előállított monodiszperz, gömb alakú $\mathrm{ZnO}$ részecskék szintézisét, valamint a szerkezeti és morfológiai tulajdonságok meghatározására készített vizsgálatokat (TEM és SEM felvételek, $\mathrm{N}_{2}$ adszorpciós-deszorpciós izotermák, XRD diffraktogramok, SAXS görbék). A részecskék víz/levegő határflületbeni viselkedésének jellemzésére bemutatom Langmuir-filmjeik oldalnyomás vs. terület izotermáit. A szilárd hordozón kialakított egyés többrétegü Langmuir-Blodgett-filmeket optikai módszerekkel jellemzem: UV-Vis transzmittancia, reflektancia és fluoreszcencia emissziós spektumokat mutatok be. Hullámosított felszínü bélyegző segítségével önrendeződéses elven mintázott felületeket állítottam elő a 341 nm-es átlagos átmérőjü részecskékkel. A mintázatok szerkezeti, optikai és fluoreszcenciás tulajdonságait ugyanezen részecskék szabálytalan szerkezetű filmjeivel összehasonlítva mutatom be.

\section{VI.1 Monodiszperz, gömb alakú részecskék szintézise 200-500 nm mérettartományban}

Monodiszperz $\mathrm{ZnO}$ részecskék dietilén-glikol közegü szintéziséről elsőként Jezequel és munkatársai [39] számoltak be. Az egylépéses szintézist kívánták reprodukálni Seelig és munkatársai, sikertelenségük azonban egy kétlépéses eljárás kidolgozását eredményezte [40]. Az új módszerrel az első lépésben az eredeti recept alapján nyert szolt lecentrifugálták, majd egy második szintézis közben a felülúszó bizonyos részletét hozzáadták a reakcióelegyhez mintegy beoltó oldatként. Munkám során elsőként Seelig és munkatársainak eljárását alkalmaztam, azonban ezzel a módszerrel bidiszperz rendszereket sikerült előállítanom. Egy ilyen bidiszperz szol részecskéiröl készült TEM képet mutat a 44. ábra a) része. Ezt követően az egylépéses szintézist autoklávban valósítottam meg, ahol a szintézis paraméterei pontosan szabályozhatók. A zárt autoklávban a reakcióelegy felfütése miatt enyhe túlnyomás jön létre, amelynek hatására polidiszperz, valamint az általam megcélzott mérettartománynál jóval nagyobb $(0,5-2 \mu \mathrm{m})$ részecskék képződtek, melyről egy jellemző képet mutat a 44. ábra b) része. Túlnyomás esetén képződő mikrométeres mérettartományba eső részecskékre példa Ashapture és munkatársainak [17] 
dolgozatában található, amelyben 1-5 $\mu \mathrm{m}$ átmérőjü, fánk alakú $\mathrm{ZnO}$ részecskék előállításáról számolnak be autoklávban, magas nyomáson, valamint víz hozzáadásával. A további kísérletek során az autokláv egy szelepét levegőre nyitottam, ezáltal a reakcióelegy fölött atmoszférikus nyomás uralkodott, amelynek eredményeképpen sikerült előállítanom különbözö méretü, monodiszperz ZnO részecskéket tartalmazó szolokat a 200-500 nm mérettartományban. Az eljárás kulcsfontosságú paraméterei a felfütési sebesség, a reakció hőmérséklete, illetve a keverés megfelelő intenzitása, valamint az, hogy az autoklávban atmoszférikus nyomás uralkodjon.
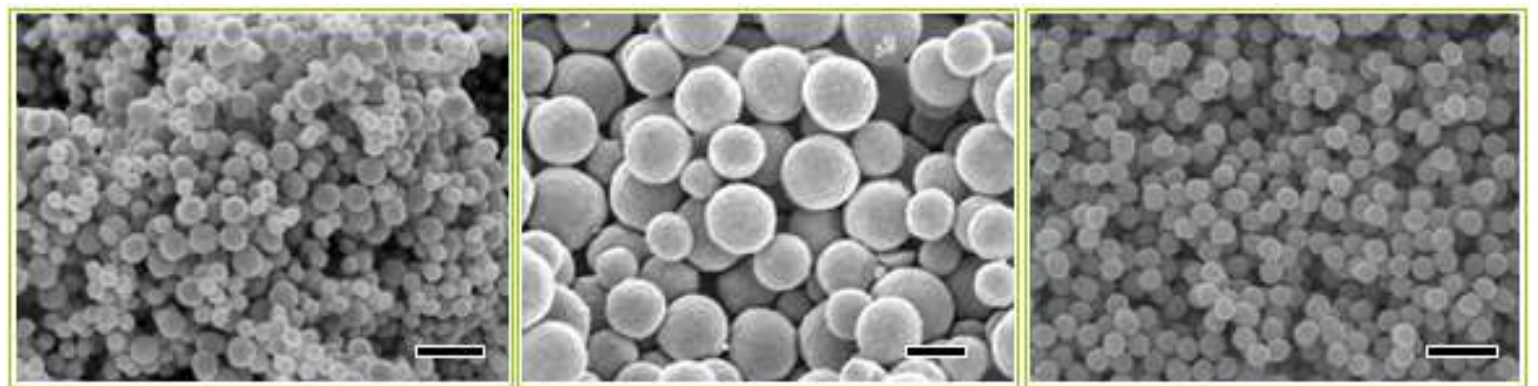

44. ábra. A dietilén-glikolban különböző módszerekkel szintetizált $\mathrm{ZnO}$ részecskék képei.

a) Egy Seelig módszerével nyert bidiszperz szol részecskéinek TEM képe, b) Jezequel módszerével zárt autoklávban képződött részecskék SEM képe, c) Jezequel módszerével nyitott autoklávban, atmoszférikus nyomáson kapott részecsék SEM képei.

(A skála mindhárom képen $1 \mu \mathrm{m}$-t jelöl.)

\section{VI.2 200-500 nm-es $\mathrm{ZnO}$ részecskék jellemzése}

Az előállított monodiszperz részecskék méretét és méreteloszlását TEM felvételek alapján jellemeztem. A 45. ábra a)-e) részábráin bemutatok egy-egy jellemző képet a részecskékről. Látható, hogy a részecskék szabályos gömb alakúak és egyforma méretủek. A szintézis során a részecskék aggregációs típusú növekedési mechanizmus szerint képződnek, amely azt jelenti, hogy a túltelített oldatból először kisméretű, primer krisztallitok válnak ki, amelyek aztán termodinamikai instabilitásuk miatt aggregálódnak, egy szekunder, nagyméretü, gömb alakú részecskét hozva létre. Ezen jelenség szemléltetésére egy SEM és egy TEM felvételt mutatok be (46. ábra), amelyeken jól látszik a részecskék felületi strukturáltsága, és az apró krisztallitok, amelyek a részecskéket alkotják. 

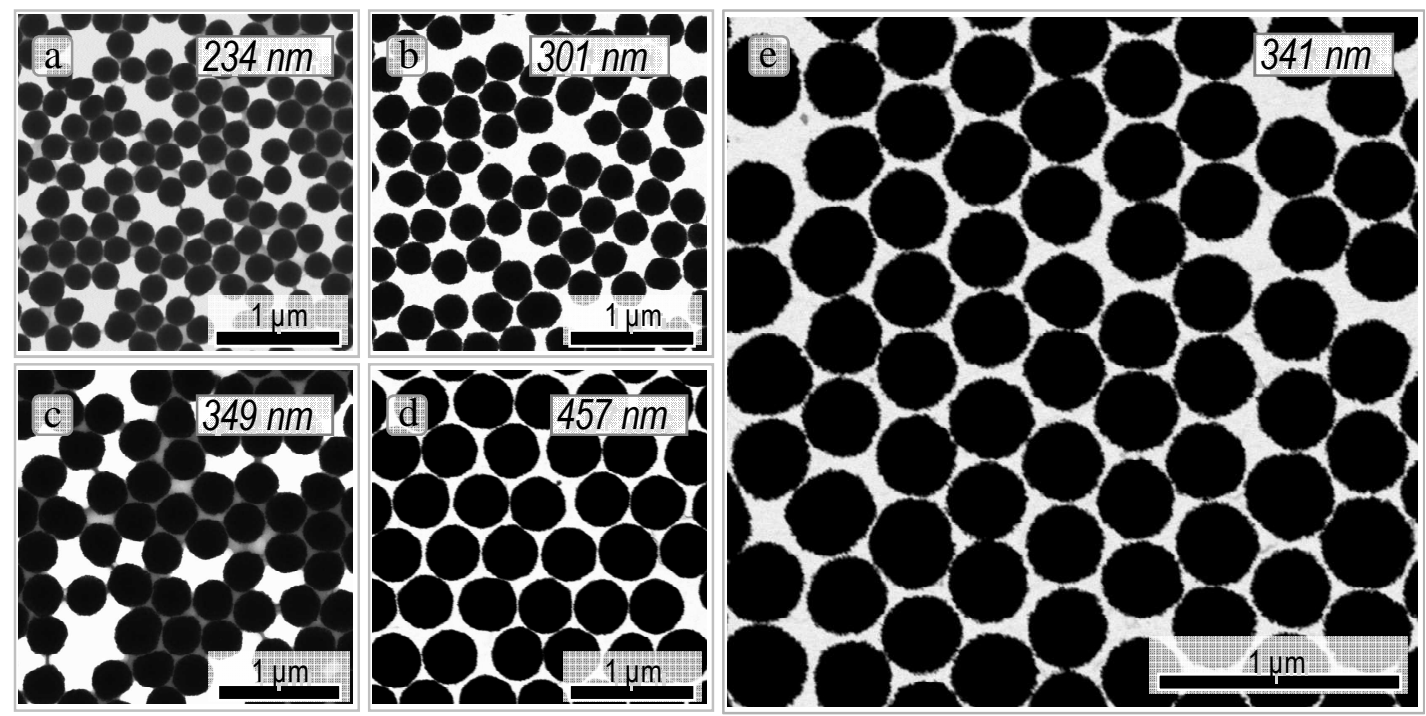

45. ábra. a)-e) A részecskék méretének jellemzésére készített TEM felvételek.
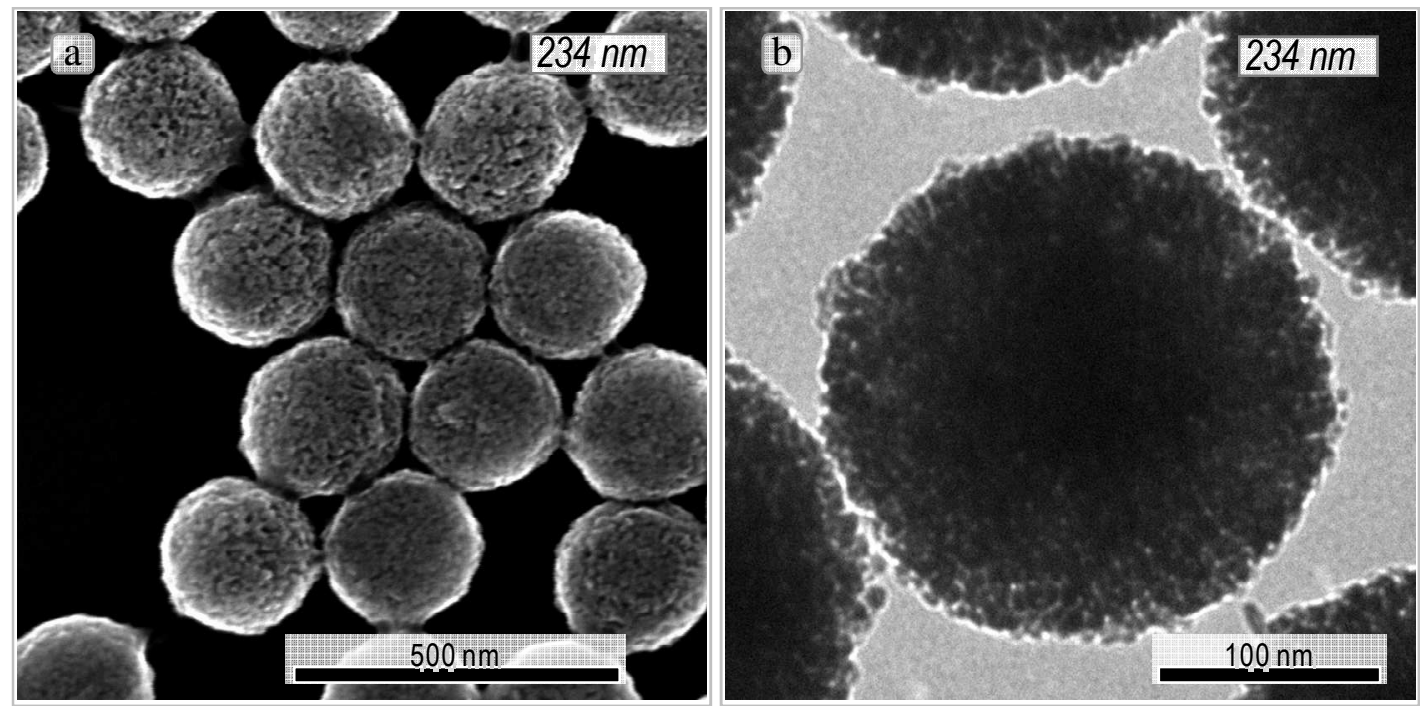

46. ábra a) A 234 nm-es $\mathrm{ZnO}$ részecskékről készített SEM felvétel, amely a részecskék felületének strukturáltságát mutatja, b) a részecskék aggregációs típusú növekedését demonstráló TEM felvétel.

Az egyes szolokban meghatározott átlagos részecskeméreteket és az átlagosan 200 db részecske átmérōjének számolásával meghatározott méreteloszlási görbéket a 47. ábra mutatja. A görbék mindegyikéröl elmondható, hogy szük méreteloszlásúak, az átlagos részecskeméret körüli szórás minden szol esetében kisebb, mint 5\%. 


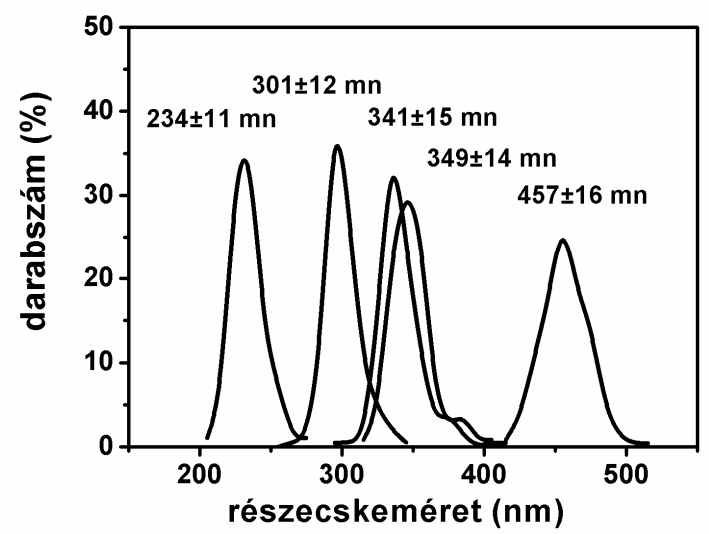

47. ábra. A különböző szolok esetén a TEM felvételek alapján meghatározott átlagos részecskeméretek és méreteloszlási görbék.

A részecskék kristályosságának jellemzésére röntgendiffrakciós (XRD) mérések készültek (48. ábra). Látható, hogy a diffraktogramokon minden részecske esetében megjelennek a hexagonális wurtzit kristályszerkezetű ZnO-ra jellemző reflexiók. A primer krisztallitok méretét a Scherrer-egyenletből ((7) egyenlet) a $36,25^{\circ} 2 \theta$ fokhoz tartozó vonalszélesedésekből számoltam ki, amelyek alapján megállapítható, hogy a részecskéket 9-15 nm-es kristályos egységek alkotják. Az egyes szolok esetében meghatározott pontos értékeket a 4. táblázatban tüntetem fel.

4. táblázat. A ZnO részecskék jellemzői TEM, XRD és $\mathrm{N}_{2}$ adszorpciós-deszorpciós mérések alapján.

\begin{tabular}{lrrrrr}
\hline $\mathbf{d}, \mathbf{n m}$ & $\mathbf{2 3 4} \pm \mathbf{1 1}$ & $\mathbf{3 0 1} \pm \mathbf{1 2}$ & $\mathbf{3 4 1} \pm \mathbf{1 5}$ & $\mathbf{3 4 9} \pm \mathbf{1 4}$ & $\mathbf{4 5 7} \pm \mathbf{1 6}$ \\
\hline $\mathbf{d}_{\text {primer, }}, \mathbf{n m}$ & 9,7 & 14,5 & 11,0 & 12,3 & 9,6 \\
$\mathbf{a}^{\mathrm{s}}{ }_{\text {BET }}, \mathbf{~ m}^{2} / \mathbf{g}$ & 57 & 66 & 69 & 79 & 71 \\
$\boldsymbol{\rho}_{\text {részecske, }} \mathbf{g} / \mathbf{c m}^{\mathbf{3}}$ & 3,83 & 3,54 & 3,34 & 3,41 & 3,63 \\
porozitás, \% & 32 & 37 & 40 & 39 & 35 \\
\hline
\end{tabular}

Nitrogén adszorpciós-deszorpciós izotermák mérésével a részecskék fajlagos felületét és porozitását kívántam jellemezni. A különböző méretü $\mathrm{ZnO}$ részecskék esetén mért izotermákat és a BJH módszerrel meghatározott pórusméret eloszlást a 49. ábra mutatja, a számszerü eredményeket (fajlagos felület $\left(\mathrm{a}_{\mathrm{BET}}^{\mathrm{S}}\right.$ ), porozitás ( $\mathrm{p}$ ) és sürüség $\left(\rho_{\mathrm{p}}\right)$ ) a 4. táblázat tartalmazza. A részecskék nagy fajlagos felülettel és jelentős porozitással bírnak, amelyre a képződési mechanizmusuk ad magyarázatot: a kolloid alegységek aggregációjával létrejövő részecskékben a primer elemek közötti hézagok 


\section{Eredmények II. rész 200-500 nm-es cink-oxid részecskék és filmjeik 67}

mezopórusokként jelennek meg és mint olyanok, növelik a fajlagos felületet. A pórusok átlagos mérete minden minta esetén 3 és 4 nm közé esik.

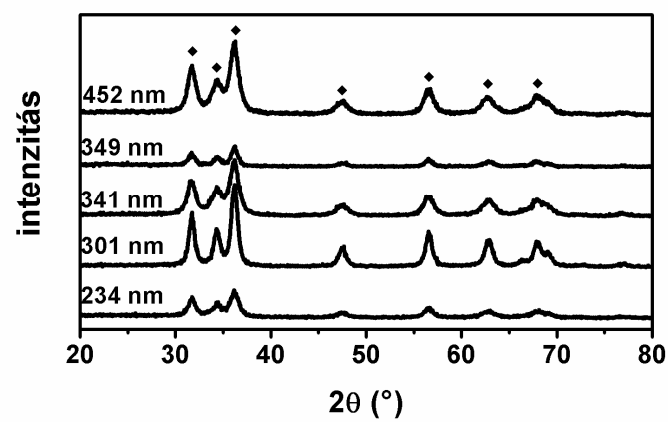

48. ábra. A különböző méretủ $\mathrm{ZnO} \mathrm{részecskék} \mathrm{pormintáiról} \mathrm{felvett} \mathrm{röntgen} \mathrm{diffraktogramok.}$

a)

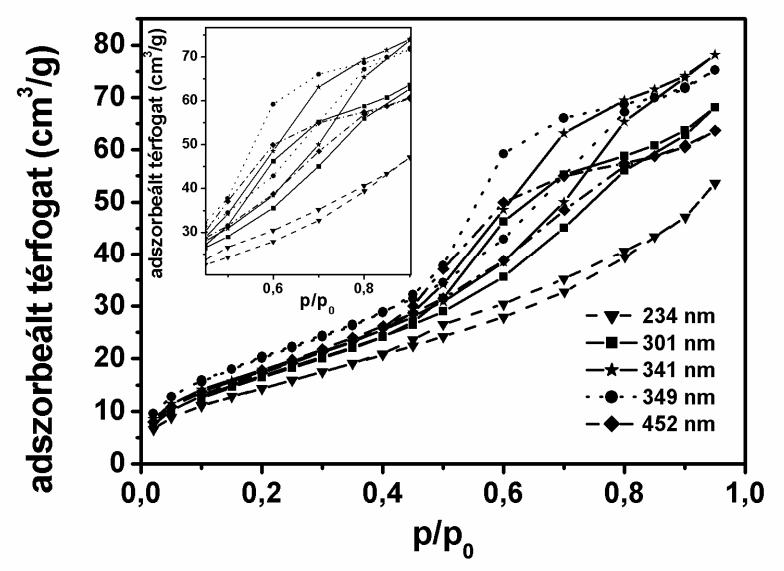

b)

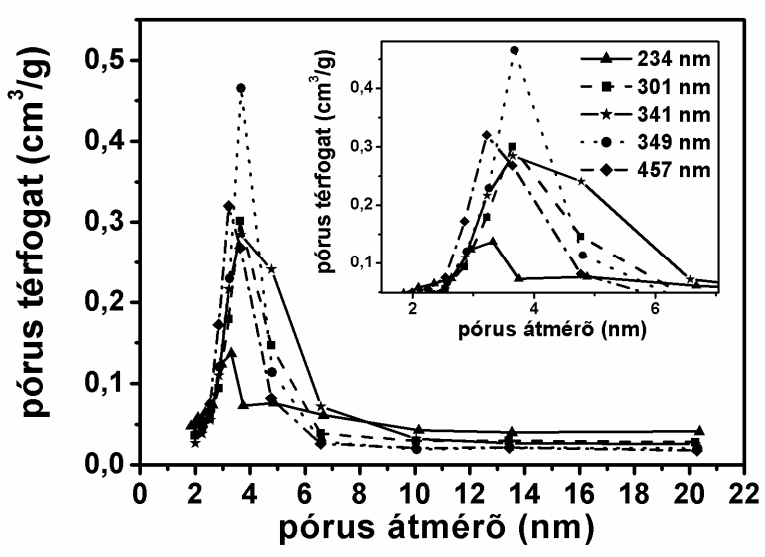

49. ábra. a) A különböző méretü $\mathrm{ZnO}$ részecskék $\mathrm{N}_{2}$ adszorpciós - deszorpciós izotermái és b) az izotermák alapján meghatározott pórusméret-eloszlások.

A részecskék szerkezetének további jellemzésére készített kisszögü röntgenszórás (SAXS) mérésekböl kapott szórásgörbéket az 50. ábra mutatja, a belölük számított jellemzők értékeit pedig az 5. táblázat tartalmazza. A mérési eredmények feldolgozásának 
menetét az 1. Függelékben részletezem. A tömegfraktál dimenzió $\left(D_{m}, 1 \leq D m \leq 3\right)$ a minta pórusosságára jellemző adat. $\mathrm{Ha} \mathrm{D}_{\mathrm{m}}=1$, a minta magas porozitású, főleg pórusok alkotják, ha $\mathrm{D}_{\mathrm{m}}=3$ esetén pedig a minta tömör, kompakt, nem tartalmaz pórusokat. A különböző méretű részecskék esetén meghatározott értékek 2,5-2,7 között vannak, a 457 nm-es részecskék esetén kisebb, 1,85-os értéket kaptunk. Ezek a mérések is azt igazolják, hogy a részecskék pórusosak, azonban a tendencia nem egyezik meg a nitrogén adszorpciós-deszorpciós méréseknél tapasztalttal (lásd 4. táblázat), ennek oka lehet a minták eltérő mértékü zárt porozitása.

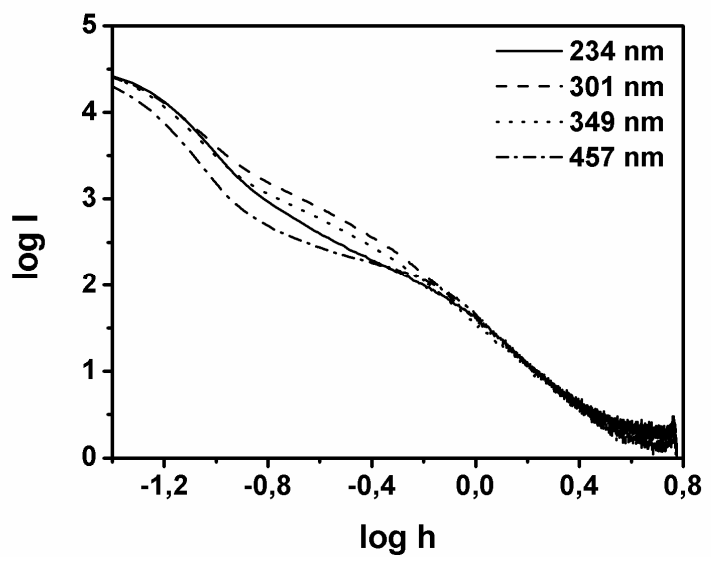

50. ábra. A SAXS mérések során kapott szórásgörbe a különböző méretü ZnO részecskék esetén.

5. táblázat. A $\mathrm{ZnO}$ részecskék meghatározott $\mathrm{SAXS}$ paraméterek. (A táblázatban használt jelölések magyarázata: $\mathrm{D}_{\mathrm{m}}$ : tömegfraktál dimenzió, $\mathrm{D}_{\mathrm{s}}$ : felületi fraktál dimenzió, $\mathrm{K}_{\mathrm{P}}$ : Porodkonstans, $\mathrm{M}_{1}$ : szórásgörbe első momentuma, $\mathrm{S} / \mathrm{V}$ : relatív belső felület, $\mathrm{S}_{\mathrm{p}}$ : fajlagos felület, $1_{c}$ : korrelációs hossz (inhomogenitási hossz a teljes mintára), $\mathrm{L}_{1}$ : inhomogenitási hossz az 1 . fázisra, $\mathrm{L}_{2}$ : inhomogenitási hossz a 2. fázisra.)

\begin{tabular}{ccccc}
\hline $\mathbf{d}, \mathbf{n m}$ & $\mathbf{2 3 4}$ & $\mathbf{3 0 1}$ & $\mathbf{3 4 9}$ & $\mathbf{4 5 7}$ \\
\hline $\mathbf{D}_{\mathbf{m}}$ & 2,5 & 2,7 & 2,7 & 1,85 \\
$\mathbf{D s}$ & 2,3 & 2,5 & 2,4 & 2,4 \\
$\mathbf{K}_{\mathbf{p}}\left(\mathbf{C p s} / \mathbf{n m}^{\mathbf{3}}\right)$ & 43,2 & 42,1 & 38,7 & 41,58 \\
$\mathbf{M}_{\mathbf{1}}\left(\mathbf{C p s} / \mathbf{n m}^{2}\right)$ & 177 & 1145,00 & 191 & 642,00 \\
$\mathbf{K}_{\mathbf{p}} / \mathbf{M}_{\mathbf{1}}$ & 0,244 & 0,193 & 0,202 & 141,00 \\
$\mathbf{S} / \mathbf{V}\left(\mathbf{n m}^{2} / \mathbf{n m}^{\mathbf{3}}\right)$ & 0,244 & 0,192 & 0,201 & 0,29 \\
$\mathbf{S}_{\mathbf{p}}\left(\mathbf{m}^{\mathbf{2}} \mathbf{\mathbf { g }}\right)$ & 115 & 92 & 105 & 142,46 \\
$\mathbf{l}_{\mathbf{c}}(\mathbf{n m})$ & 11,3 & 10,5 & 10,8 & 9,05 \\
$\boldsymbol{L}_{\boldsymbol{l}}(\mathbf{n m})$ & 11,9 & 14,7 & 10,4 & 8,96 \\
$\boldsymbol{L}_{\mathbf{2}}(\mathbf{n m})$ & 23,0 & 29,0 & 27,6 & 19,12 \\
\hline
\end{tabular}


A felületi fraktál dimenzió $\left(D_{s}, 2 \leq D_{s} \leq 3\right)$ a minta felületét jellemzi: $D_{s}=2$ esetén a mintafelszín teljesen sima, míg $\mathrm{D}_{\mathrm{s}}=3$ esetén a felület érdes, fragmentált. A mintáim esetén meghatározott értékek 2,3 és 2,5 közé esnek, tehát ezek a mérések is mutatják a részecskék tagolt felszínét, amely az aggregációs típusú növekedésnek köszönhető. A SAXS mérésekből számolt fajlagos felület $\left(S_{\mathrm{p}}\right)$ értékek jelentősen nagyobbak, mint a $\mathrm{N}_{2}$ adszorpciós-deszorpciós izotermák alapján meghatározott értékek. Ennek oka lehet a minták zárt porozitása: a nitrogén molekulák számára nem hozzáférhető helyeken, a részecskék belsejében található pórusok SAXS módszerrel kimutathatók. A minták pórusosságát jellemző tömegfraktál dimenzió $\left(D_{m}\right)$ és a fajlagos felület $\left(S_{p}\right)$ értékek tendenciái jó egyezést mutatnak. A ZnO fázisra jellemző inhomogenitási hossz $\left(\mathrm{L}_{1}\right)$ értékek $10 \mathrm{~nm}$ körülinek adódtak. Ezek az értékek jó egyezést mutatnak a röntgen diffraktogramokból meghatározott primer krisztallitok méretével. A levegő fázisra jellemző inhomogenitási hossz $\left(\mathrm{L}_{2}\right)$ értékek jóval nagyobbak, mint az adszorpciós mérésekből számolt pórusméretek. Ennek a két adatnak azonban nem is kell megegyeznie, hiszen a SAXS mérésekből meghatározott hosszúság értékek tartalmazzák a részecskék közötti levegőt is, nem csak a pórusokban lévőt.

\section{VI.3 200-500 nm-es ZnO részecskék Langmuir-filmjeinek jellemzése}

Langmuir mérlegen végzett kísérletek során jellemeztem a $\mathrm{ZnO}$ részecskék 2D filmjeinek kialakulását víz/levegő határfelületen. Az oldalnyomás ( $\pi$ ) vs. terület (A) izotermák mérésével jellemeztem a vízfelszíni filmet, a részecskék tulajdonságait a vízfelszínen. Az 51. ábra a) részén láthatók a különböző méretű részecskék esetén mért izotermák, valamint feltüntettem az izotermából meghatározható paramétereket is. Az izotermák nagyon hasonló lefutást mutatnak: amikor a részecskék egymáshoz közel kerülnek a rendelkezésükre álló vízfelszíni terület csökkentésekor, az oldalnyomás nagyon meredeken kezd nőni és ez a kollapszus bekövetkezéséig tart. A kollapszus pontban egy töréspont látható az izotermán, amely után tovább nő az oldalnyomás, azonban kisebb meredekséggel. A görbékről meghatározott kollapszus nyomás $\left(\pi_{\mathrm{c}}\right)$, kollapszus terület $\left(\mathrm{A}_{\mathrm{c}}\right)$ és kontakt keresztmetszeti terület $\left(\mathrm{A}_{\mathrm{k}}\right)$ értékeket a különböző méretü $\mathrm{ZnO}$ részecskék esetén a 6. táblázatban foglaltam össze. Látható, hogy a meghatározott terület értékek egységnyi tömegü szétterített részecske esetén a méret növekedésével csökkennek: 
triviális, hogy egységnyi tömeg vastagabb filmje kisebb területet foglal el (a filmvastagság megegyezik a részecskeátmérővel).

a)

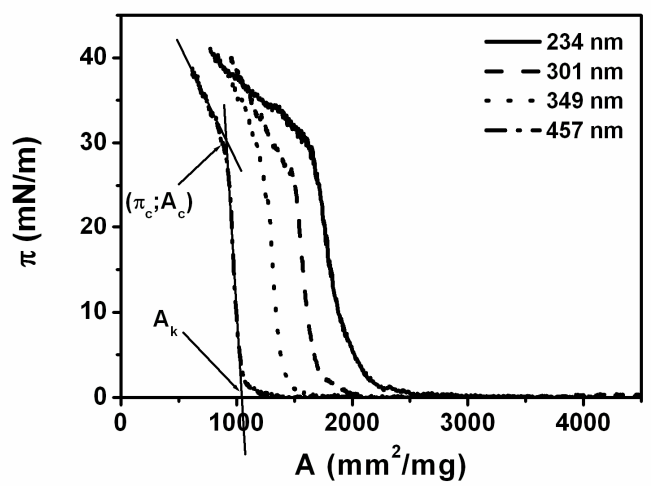

b)

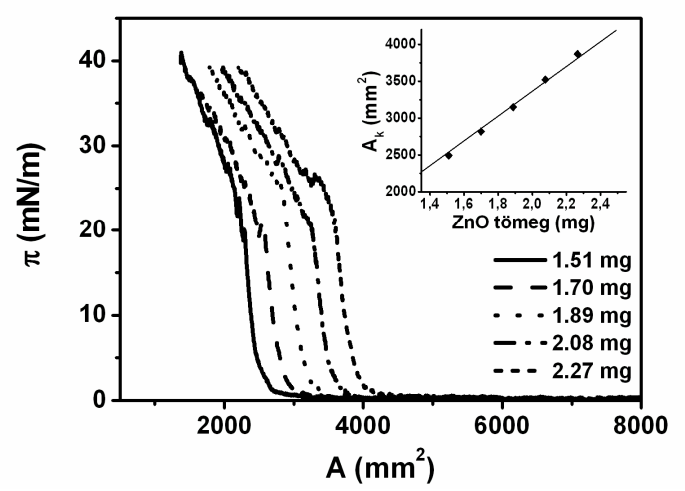

51. ábra. a) A különböző méretü $\mathrm{ZnO}$ részecskék esetén mért oldalnyomás vs. terület izotermák. b) A 301 nm-es részecskék esetében különböző terített $\mathrm{ZnO}$ mennyiségek esetén mért izotermák, beillesztett ábra: a kontakt keresztmetszeti terület értékek a $\mathrm{ZnO}$ tömegének függvényében.

A kontakt keresztmetszeti területből a vízfelszínre terített részecskék mennyiségének ismeretében meghatároztam az egy részecskére jutó átlagos terület értékét $\left(\mathrm{A}_{1}\right)$ az (5) egyenlet segítségével. A (6) egyenlet alapján kiszámoltam az átlagos méretü részecske köré írható hatszög területét, amely egy részecske helyigényét jellemzi a filmben. Ezeket az értékeket az 6. táblázat tartalmazza. Látható, hogy a kísérletileg meghatározott értékek valamivel nagyobbak, mint az elméleti számok, azonban az adatok jó egyezést mutatnak. Ebből azt a következtetést lehet levonni, hogy a részecskék a terítés során gyakorlatilag veszteség nélkül a vízfelszínre jutnak, a kompresszió során nem süllyednek a szubfázisba, valamint a tömör vízfelszíni filmben a részecskék szorosan illeszkednek, jól rendezett film alakítható ki.

6. táblázat. Az oldalnyomás-terület izotermákból meghatározott paraméterek $\left(\pi_{c}, A_{c}, A_{k}\right)$, valamint az 1 részecskére jutó terület nagysága az izotermák alapján $\left(A_{1}\right)$ és elméleti számolással $\left(A_{H}\right)$.

\begin{tabular}{cccccc}
\hline $\mathbf{d}, \mathbf{n m}$ & $\boldsymbol{\pi}_{\mathrm{c}}(\mathbf{m N} / \mathbf{m})$ & $\mathbf{A}_{\mathbf{c}}\left(\mathbf{m m}^{2} / \mathbf{m g}\right)$ & $\mathbf{A}_{\mathbf{k}}\left(\mathbf{m m}^{2} / \mathbf{m g}\right)$ & $\mathbf{A}_{\mathbf{1}}\left(\mathbf{n m}^{2} / \mathbf{d} \mathbf{b}\right)$ & $\mathbf{A}_{\mathrm{H}}\left(\mathbf{n m}^{2} / \mathbf{d} \mathbf{b}\right)$ \\
\hline $\mathbf{2 3 4}$ & 30,3 & 1646 & 1964 & $5,05 \cdot 10^{4}$ & $4,74 \cdot 10^{4}$ \\
$\mathbf{3 0 1}$ & 26,5 & 1493 & 1664 & $8,41 \cdot 10^{4}$ & $7,85 \cdot 10^{4}$ \\
$\mathbf{3 4 9}$ & 29,1 & 1238 & 1377 & $1,06 \cdot 10^{5}$ & $1,05 \cdot 10^{5}$ \\
$\mathbf{4 5 7}$ & 30,5 & 910 & 1047 & $1,9 \cdot 10^{5}$ & $1,81 \cdot 10^{5}$ \\
\hline
\end{tabular}

Vizsgáltam a terített mennyiség hatását: az 51. ábra b) részábráján egy izoterma sorozatot mutatok be a $301 \mathrm{~nm}$-es részecskék esetén különböző felvitt $\mathrm{ZnO}$ mennyiség esetén, a beillesztett ábrán az izotermából meghatározott kontakt keresztmetszeti terület értékeket a ZnO tömegének függvényében ábrázoltam. Megállapítható, hogy az izotermák 
azonos lefutásúak és a kontakt keresztmetszeti terület értékek lineárisan változnak a terített mennyiség függvényében, tehát a filmképzés és az izotermák jól szabályozhatóak, jól kézben tartható a mérési eljárás.

\section{VI.4 200-500 nm-es ZnO részecskék Langmuir-Blodgett-filmjeinek jellemzése}

A Langmuir-Blodgett technikával Si lapra felépített egyrétegű filmek szerkezetét, a részecskék rendezettségét pásztázó elektronmikroszkóppal készített felvételekkel jellemeztem. A különböző méretü részecskék esetén készített képeket az 52. ábra foglalja össze. Az egyrétegü filmekről megállapítható, hogy bennük a részecskék valóban egy rétegben helyezkednek el, nincsenek aggregált vagy egymásra torlódott részek. A részecskék rendezettsége meglehetősen jó, de azért nem tökéletes, a filmeket hatszöges rendeződést mutató domének alkotják. Látható továbbá, hogy a nagyobb részecskékből épített filmek rendezettsége sokkal jobb, a 349 nm-es és 457 nm-es $\mathrm{ZnO}$ részecskék filmjei már alig tartalmaznak hibákat.
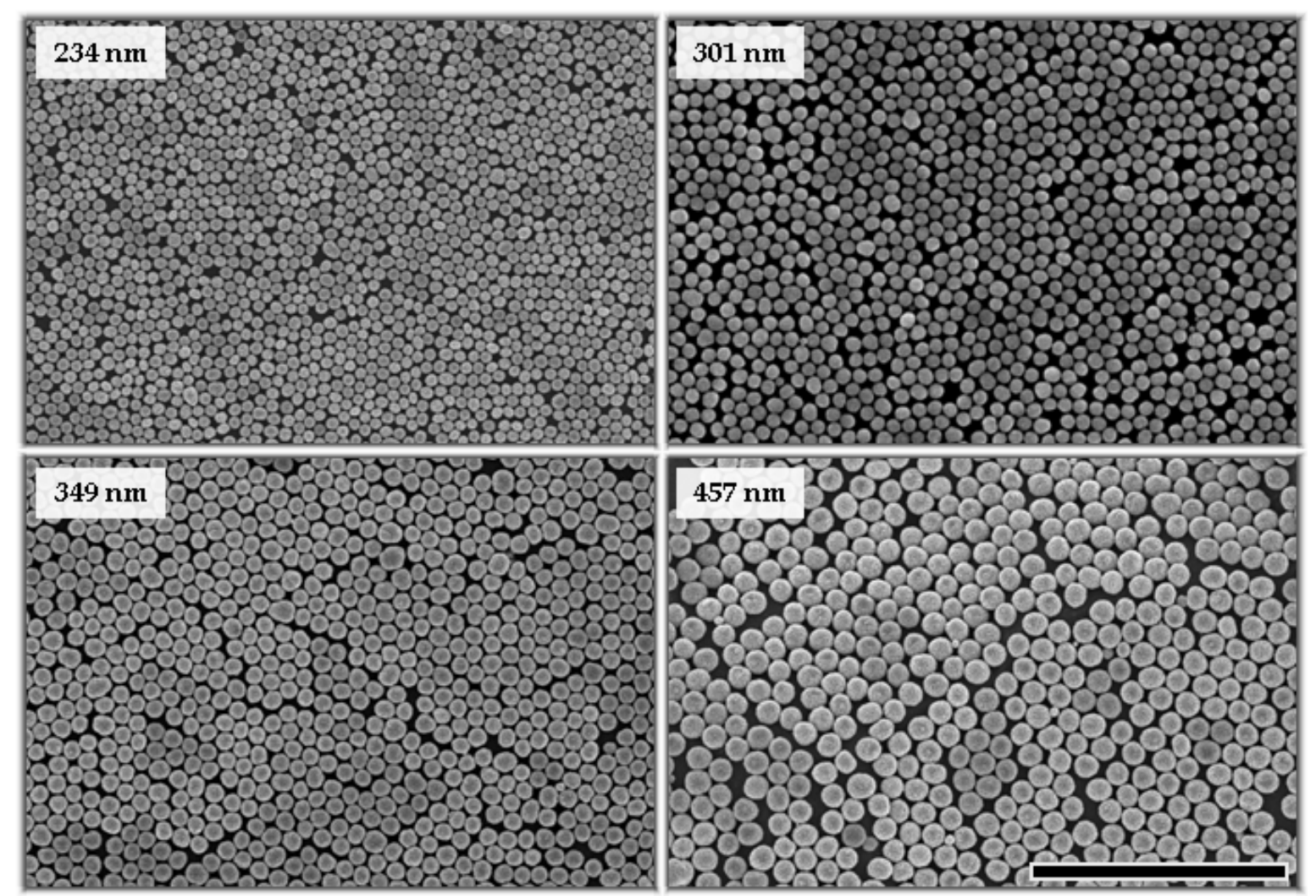

52. ábra. A különböző méretű ZnO részecskékből Si lapra épített egyrétegü filmek SEM képe (skála: $5 \mu \mathrm{m}$ ). 
A 234 nm-es ZnO részecskék üveglapra épített filmjeit transzmittancia és reflektancia spektrumokkal jellemeztem. Ezekböl a részecskékből 1-5 rétegü filmeket építettem és minden rétegszámnál mértem a film transzmittancia és a $45^{\circ}$-os reflektancia spektrumát. A transzmittancia spektrumokból (53. ábra) látható a film rétegenkénti épülése: a film áteresztése csökken és megjelennek a film reflexiója miatti hullámok.

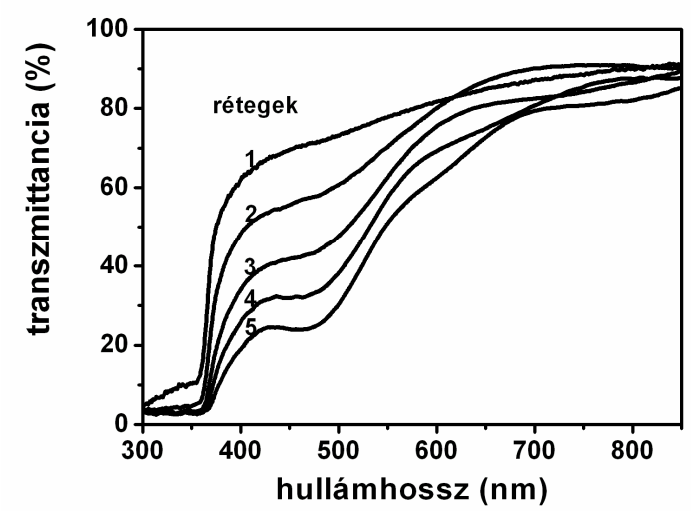

53. ábra. A 234 nm-es $\mathrm{ZnO}$ részecskékből felépített többrétegü filmek transzmittancia spektruma.

A vékony filmek reflexió spektrumainak kiértékelésére a tanszékünkön Sebők Dániel egy szimulációs programot késztett, amelynek segítségével meghatározható a filmek törésmutatója és vastagsága. Ezt a szimulációt továbbfejlesztettem, a modellbe beépítettem a saját filmjeim speciális tulajdonságait: gömb alakú, hexagonálisan rendezett részecskék meghatározott rétegszámú filmjei.

Az optikai modell alapja a hullámok interferenciája plán paralell lemezen. A modellszámtáshoz használt egyenlet levezetése a tanszékünkön készült korábbi közleményben [ 144 ] megtalálható, itt nem térek ki a részletekre. A levezetés eredményeképpen a visszaverődő interferált hullám intenzitása $\left(I_{R}\right)$ különböző hullámhosszakon az alábbi kifejezéssel becsülhető:

$$
I_{R} \sim a^{2}\left[r^{2}+2 r r^{\prime}\left(1-r^{2}\right) \cos \frac{4 \pi m_{e f f} H \cos \beta}{\lambda}+r^{2}\left(1-r^{2}\right)^{2}\right] .
$$

A képletben használt jelöléseket az 54. ábra magyarázza. A modell továbbfejlesztése során a korábban a Bruggemann módszerrel számolt effektív törésmutatót lecseréltem és a saját rendszeremre jobban illeszkedő számításokkal helyettesítettem. A film effektív törésmutatójának számolásakor figyelembe vettem a részecskék porozitását, filmbeli tömörségüket és a rétegszámot is. További újítás, hogy a filmek vastagságát a rétegszám, a 


\section{Eredmények II. rész 73 \\ 200-500 nm-es cink-oxid részecskék és filmjeik}

részecskeátmérő és a részecskék filmbeli távolságának függvényében számolom, nem pedig kiindulási paraméterként szerepeltetem.

A filmek effektív törésmutatóját a részecskék törésmutatója és a részecskék filmbeli tömörsége alapján számoltam. A részecskék törésmutatóját a porozitásuk alapján határoztam meg, a számolásához a Lorentz-Lorenz formulát használtam. Ezek alapján egy részecske törésmutatója [145]:

$$
\frac{n_{p}^{2}-1}{n_{p}^{2}+2}=\sum_{i} f_{i} \frac{n_{i}^{2}-1}{n_{i}^{2}+2}=f_{Z n O} \frac{n_{Z n O}^{2}-1}{n_{Z n O}^{2}+2},
$$

ahol $n_{p}$ a részecske törésmutatója, $f_{Z n O}$ a $\mathrm{ZnO}$ fázis térfogattörtje, $n_{Z n o}$ pedig a tömbfázisú $\mathrm{ZnO}$ törésmutatója. A $\mathrm{ZnO}$ hullámhosszfüggő tömbfázisú törésmutatóját az alábbi analitikai formulával számítottam:

$$
n_{\mathrm{ZnO}}=a+b / \lambda^{2},
$$

ahol $a$ és $b$ konstansok ( $a=1,84, b=26,667), \lambda$ pedig a hullámhossz nm-ben. A ZnO fázis térfogattörtjét a porozitás $(p, \%)$ ismeretében a következő egyenlettel lehet meghatározni:

$$
f_{\text {ZnO }}=(100-p) / 100
$$

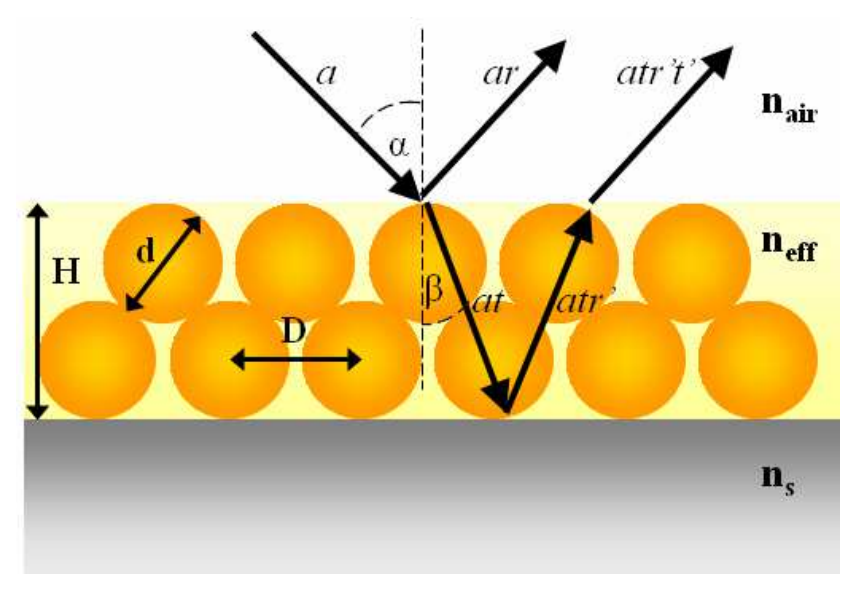

54. ábra. Az optikai modellben használt paraméterek szemléltetése. (H (nm): filmvastagság; $\mathrm{d}(\mathrm{nm})$ : részecskék átméröje; $\mathrm{D}(\mathrm{nm})$ : két részecske középpontja közti távolság; $\mathrm{n}_{\text {air }}$ : levegő törésmutatója; $\mathrm{n}_{\text {eff: }}$ film effektív törésmutatója; $\mathrm{n}_{\mathrm{s}}$ : hordozó törésmutatója; $\alpha$ : beesési szög; $\beta$ : törési szög; $a, r, t, r^{\prime}, t^{\prime}:$ amplitúdók)

A filmek vastagságát $(H, \mathrm{~nm})$ a következő összefüggéssel számoltam [145]:

$$
H=d+(k-1) \sqrt{d^{2}-\frac{D^{2}}{3}},
$$


ahol $d$ az átlagos részecskeátmérő nm-ben, $k$ a rétegszám és $D$ a nm-ben megadott távolság két szomszédos részecske középpontja között (lásd 54. ábra). A részecskék térfogattörtje a filmben $\left(f_{p}\right)$ a filmvastagság és a részecskék középpontja közötti távolság ismeretében a következőképpen adható meg:

$$
f_{p}=\frac{k d^{3} \pi}{3 \sqrt{3} D^{2} H} .
$$

A film effektív törésmutatója a részecskék törésmutatójának és filmbeli térfogattörtjének ismeretében a Lorentz-Lorenz formulával a következőképpen számolható:

$$
\frac{n_{e f f}^{2}-1}{n_{e f f}^{2}+2}=f_{p} \frac{n_{p}^{2}-1}{n_{p}^{2}+2},
$$

ahol $n_{\text {eff }}$ az effektív törésmutató.

A fent leírt módon meghatározott törésmutató és filmvastagság értékeket helyettesítettem be az (13) egyenletbe, amellyel közelítettem a mért reflektancia spektrumokat. A kiindulási paraméterek változtatásával megkerestem a számolt görbe legjobb illeszkedését a mért spektrumokhoz. Az illesztés jóságának megállapítása során a görbék szélsőértékei közötti eltérést vettem figyelembe. A legjobb illeszkedéshez tartozó értékek adják meg a film jellemző tulajdonságait: a filmvastagságot, effektív törésmutatót és a részecskék térfogattörtjét a filmben. A mért és az illesztett spektrumokat 1-5 rétegszámok esetén az 55. ábra a) részén mutatom be, a film hullámhosszfüggő effektív törésmutatója az 55. ábra b) részén látható. Az eredményül kapott filmvastagság és részecske térfogattört értékeket a 7. táblázat tartalmazza.

a)

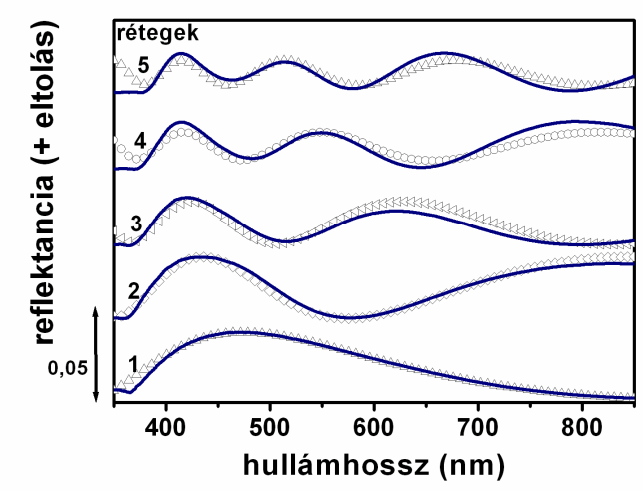

b)

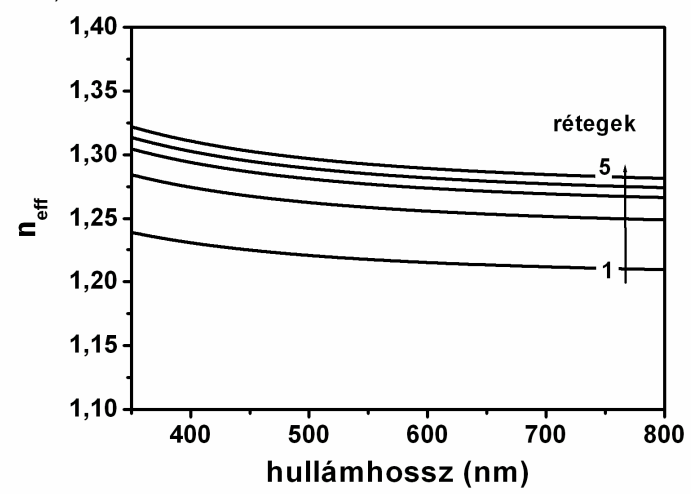

55. ábra. a) A 234 nm-es $\mathrm{ZnO}$ részecskékből felépített 1-5 rétegủ filmek mért (folytonos vonal) és számított (szimbólumok) reflexió spektruma. b) Az optikai modell alapján meghatározott effektív törésmutató értékek a 234 nm-es részecskék 1-5 rétegü filmjeire. 


\section{Eredmények II. rész 75 \\ 200-500 nm-es cink-oxid részecskék és filmjeik}

A mért és illesztett spektrumok viszonyáról elmondható, hogy az egyrétegű film esetében széles hullámhossz tartományban $(\sim 400-850 \mathrm{~nm})$ jó illeszkedés mutatkozik. A 400 nm-es alsó határt a ZnO filmek elnyelése okozza, ugyanis a modell nem számol a film abszorbanciájával, ezért csak abban a tartományban alkalmazható, ahol elhanyagolható az elnyelés. A kétrétegü film esetén még mindig meglehetősen széles hullámhossz tartományban megfelelő az illesztés ( 400-800 nm). A három- és többrétegü filmeknél viszont már sokkal keskenyebb tartományban elfogadható az illesztés ( 430-570), ennek megfelelően csak ebben a hullámhossztartományban fogadhatók el az eredmények.

7. táblázat. A $234 \mathrm{~nm}$-es $\mathrm{ZnO}$ részecskék különböző rétegszámú ( $k$ ) filmjei esetén kapott filmvastagság $(H)$ és részecske térfogattört értékek $\left(f_{p}\right)$.

\begin{tabular}{cccccc}
\hline $\boldsymbol{k}$ & $\mathbf{1}$ & $\mathbf{2}$ & $\mathbf{3}$ & $\mathbf{4}$ & $\mathbf{5}$ \\
\hline $\boldsymbol{H}, \mathbf{n m}$ & 234 & 409 & 586 & 764 & 940 \\
$\boldsymbol{f}_{p}$ & 0,4475 & 0,5202 & 0,5562 & 0,5735 & 0,5822 \\
\hline
\end{tabular}

A film effektív törésmutatója a rétegszám növekedésével nő (55. ábra b) része). Ennek a magyarázata, hogy magasabb rétegszámoknál nagyobb a részecskék térfogattörtje a filmben: a részecskék az előző rétegben lévő részecskék közeibe ülnek be. Ez a tendencia a rétegvastagság nagyságában is megmutatkozik.

Összességében megállapítható, hogy a modell nagyon jó egyezést mutat a mérésekkel egy és kétrétegü filmek esetén, három- és nagyobb rétegszámok esetében azonban már kevésbé jól írja le a film tulajdonságait, aminek több oka lehet. A film elnyelése a rétegszámmal nő (53. ábra) a növekvő ZnO mennyiség miatt, ugyanakkor a modell nem számol a film abszorbanciájával. (Többek között a filmek abszorpciójának figyelmen kívül hagyása az oka annak, hogy a 200-500 nm mérettartományban előállított részecskék közül csak a legkisebbekből épített filmek modellezhetők reflektancia mérésekhez. A nagyobb részecskék filmjeinek egyre szélesebb hullámhossz tartományban csökken az áteresztése. Továbbá a méret növekedésével egyre jelentősebbé válik a részecskéken történő fényszóródás, azaz egyre nagyobb a veszteség, amelyet a modell szintén nem tud számításba venni.) A modell pontatlanságának másik oka lehet, hogy a részecskék rendezettségében lévő kis hibák a rétegszám növekedésével összeadódnak, a sokrétegü film kevésbé jól definiált, így annak a szerkezetét már nem írja le megfelelően a modell. Meg kell említenem, hogy hexagonálisan rendezett filmek más technikákkal is 


\section{Eredmények II. rész 76 \\ 200-500 nm-es cink-oxid részecskék és filmjeik}

előállíthatók, így a modell ezen rendszerekre is jól alkalmazható lehet. Érdekes lenne kipróbálni más filmépítési technikát is a ZnO részecskéim felhasználásával, így a strukturális hibák kiküszöbölésével széles hullámhossz tartományban jó illeszkedést lehetne tapasztalni.

A 301 nm, 349 nm és 457 nm átmérőjű $\mathrm{ZnO}$ részecskékből üveglapra felépített egyrétegü Langmuir-Blodgett-filmeket UV-Vis transzmittancia spektrumokkal jellemeztem (56. ábra).

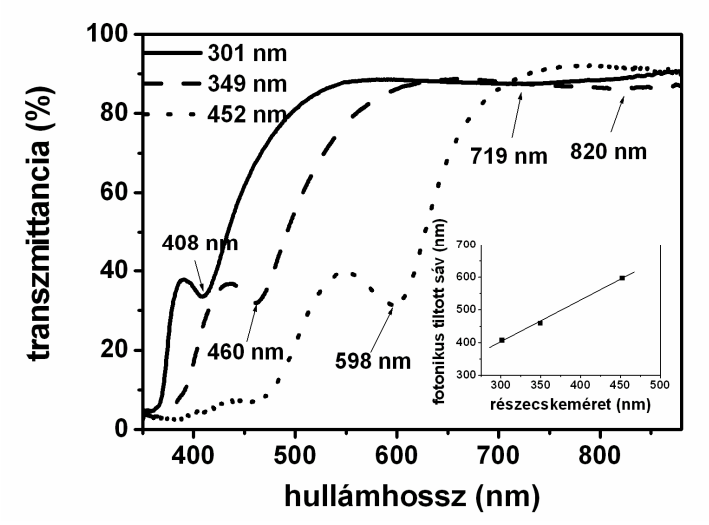

56. ábra. A 301nm-es, 349 nm-es és 457 nm-es ZnO részecskék egyrétegü üveghordozós filmjeinek transzmittancia spektruma.

A filmek a fotonikus kristályok tulajdonságát mutatják, a spektrumban látható a filmekre jellemző fotonikus tiltott sáv (fotonikus band gap). A különböző méretű $\mathrm{ZnO}$ részecskék filmjei esetén tapasztalt első- és másodrendü fotonikus tiltott sáv értékeket feltüntettem a transzmittancia spektrumokon, valamint a 8. táblázatban foglaltam össze.

A 457 nm-es részecskék esetében az elsőrendủ fotonikus tiltott sáv 900 nm-nél nagyobb hullámszámnál található, így az a mért spektrumon nem jelenik meg. A fotonikus kristályokra jellemző tiltott sáv helye a film törésmutatójának és a rácsállandó értékének ismeretében egyszerű képlettel számítható [108]:

$$
\begin{aligned}
& \lambda_{\text {max }, 1}=2 L \sqrt{n_{e f f}^{2}-\sin ^{2} \gamma}, \\
& \lambda_{\text {max }, 2}=L \sqrt{n_{e f f}^{2}-\sin ^{2} \gamma},
\end{aligned}
$$

ahol $\lambda_{\max , 1}$ és $\lambda_{\max , 2}$ az első- és másodrendű fotonikus tiltott sáv helye (nm), $L$ a rácsparaméter $(\mathrm{nm}), n_{\text {eff }}$ a film effektív törésmutatója, $\gamma$ pedig a beesési szög (a beesési szög alatt a felületi normális és a beesési egyenes közötti szöget értjük). A rácsparaméter egyrétegü filmek esetében megegyezik a filmvastagsággal, azaz a részecskék átmérőjével. 
A beesési szög ebben az esetben $\gamma=0^{\circ}$. A képletekböl látszik, hogy az elsőrendü tiltott sáv hullámhossza kétszerese a másodrendü hullámhosszának. A mintáim ettől eltérő viselkedést mutatnak (lásd 8. táblázat), az elsőrendü fotonikus tiltott sáv alacsonyabb hullámhossznál jelenik meg, mint azt a másodrendủ alapján várnánk. Ennek a magyarázata még nem ismert.

8. táblázat. A $301 \mathrm{~nm}, 349 \mathrm{~nm}$ és $457 \mathrm{~nm}$ átlagos átmérőjü részecskék egyrétegü filmjeinek transzmittancia spektrumán megjelenő elsőrendủ $\left(\lambda_{\max , 1}\right)$ és másodrendủ $\left(\lambda_{\max , 2}\right)$ tiltott sávok helyei, valamint az ezek alapján meghatározott paraméterek $\left(n_{\text {eff: }}\right.$ a film effektív törésmutatója, $n_{Z n O, \text { bulk }}$ : a $\mathrm{ZnO}$ tömbfázisú törésmutatója, $p$ : porozitás, $n_{p}$ : részecskék törésmutatója, $f_{p}$ : részecskék térfogattörtje a filmben, $D$ : két szomszédos részecske középpontának átlagos távolsága a filmben).

\begin{tabular}{ccccccccc}
\hline $\boldsymbol{d}, \mathbf{n m}$ & $\lambda_{\max , \mathbf{l}}, \mathbf{n m}$ & $\lambda_{\max , 2}, \mathbf{n m}$ & $\boldsymbol{n}_{\text {eff }}$ & $\begin{array}{c}\boldsymbol{n}_{\text {ZnO, bulk }} \\
\left(\mathbf{a t} \lambda_{\max , 2}\right)\end{array}$ & $\boldsymbol{p}, \boldsymbol{\%}$ & $\boldsymbol{n}_{p}$ & $f_{p}$ & $\boldsymbol{D}, \mathbf{n m}$ \\
\hline $\mathbf{3 0 1}$ & 719 & 408 & 1,355 & 2,000 & 36,72 & 1,633 & 0,563 & 312 \\
$\mathbf{3 4 9}$ & 820 & 460 & 1,318 & 1,966 & 39,18 & 1,688 & 0,541 & 369 \\
$\mathbf{4 5 7}$ & - & 598 & 1,309 & 1,915 & 35,13 & 1,594 & 0,522 & 492 \\
\hline
\end{tabular}

A másodrendủ fotonikus tiltott sáv helyének és a film rácsállandójának ismeretében meghatároztam a filmjeim effektív törésmutatóját a (21) egyenlet alapján, az eredményt a 8. táblázatban tüntettem fel.

A reflexió spektrumok illesztése kapcsán bemutatottakhoz hasonlóan itt is ki lehet számolni a filmek effektív törésmutatóját az alkotó fázisok törésmutatói alapján. Fotonikus kristályok esetében leggyakrabban a filmet alkotó komponensek tömbfázisú törésmutatójának a térfogattörttel súlyozott átlagát szokták használni [108]:

$$
n_{\text {eff }}=f_{p} n_{p}+f_{\text {air }} n_{\text {air }},
$$

ahol $f_{p}$ és $n_{p}$ a részecskék térfogattörtje és törésmutatója, $f_{\text {air }}$ és $n_{\text {air }}$ a levegöre vonatkozó ugyanazon paraméterek. Ugyanezt a módszert követve kiszámítható a részecskék törésmutatója a primer kristályok és a pórusok törésmutatói alapján:

$$
n_{p}=f_{Z n O} n_{Z n O}+f_{\text {air }} n_{\text {air }},
$$

ahol $f_{Z n O}$ és $n_{Z n O}$ a kristályos $\mathrm{ZnO}$ térfogattörtje és törésmutatója. A részecskék porozitásának ismeretében kiszámolható a törésmutatójuk. A részecskék filmbeli térfogattörtje $\left(f_{p}\right)$ ugyanazzal a képlettel ((18) egyenlet) számolható, amelyet korábban a filmek reflexió spektrumainak illesztésekor is felhasználtam. Tehát a (23) egyenletből meghatározott részecske törésmutatót behelyettesítve a (24) egyenletbe megkapjuk a részecskék filmbeli törésmutatóját, amely alapján a (18) egyenlet segítségével 


\section{Eredmények II. rész 78 \\ 200-500 nm-es cink-oxid részecskék és filmjeik}

megbecsülhető két szomszédos részecske középpontjának átlagos távolsága a filmben $(D)$. A részecske térfogattört és az átlagos részecske távolság értékek is lényegében azt mutatják, hogy a kisebb részecskékből tömörebb filmek kaphatók. A pásztázó elektronmkroszkópos képekkel (52. ábra) összevetve elmondható, hogy valóban a legnagyobb részecskék esetén figyelhetők meg a legnagyobb rések a filmben, azonban a másik két esetben nem látható jelentős eltérés. A számolási eredmények és a SEM felvételek közötti különbség adódhat egyrész abból, hogy a törésmutató kiszámítására használt modell tartalmaz elhanyagolásokat és ez valamelyest módosítja az eredményeket, másrész abból, hogy különböző mintadarabokon készültek a mérések. Az optikai mérésekhez ugyanis üveghordozós mintákat használtam, míg a SEM mérésekhez Si lapra készítettem el párhuzamosan ugyanazokat a mintákat.

Jellemeztem a $\mathrm{ZnO}$ részecskékből kvarchordozóra felépített egyrétegü filmek fluoreszcencia sajátságait is. Az 57. ábra a 350 nm-es gerjesztő fény alkalmazásával felvett emissziós spektrumokat mutatja.

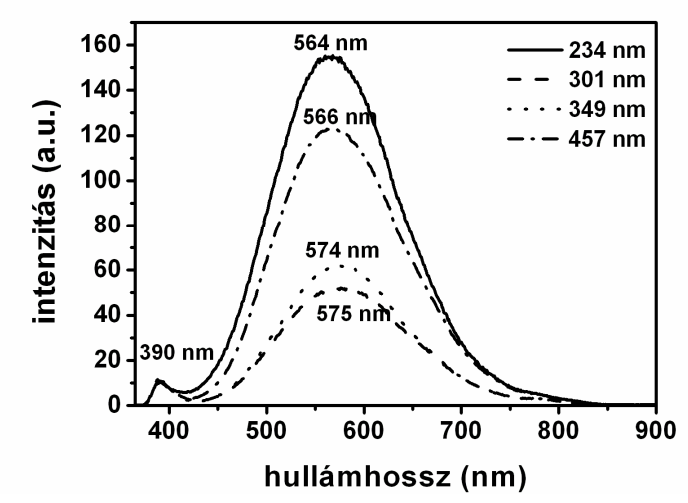

57. ábra. A 234, 301, 349 és 457 nm-es részecskék egyrétegü, kvarchordozós filmjeinek fluoreszcencia emissziós spektrumai (gerjesztés: $\lambda=350 \mathrm{~nm}$ ).

A spektrumokon megjelenik egy intenzív, széles emissziós csúcs a látható tartományban (570 nm körül), valamint egy gyengébb, élesebb csúcs az UV tartományban 390 nm-nél. A korábban (II.2. alfejezet) részletezett mechanizmus szerint az UV emisszió a gerjesztett excitonok direkt rekombinációjával magyarázható, a látható emissziót pedig a felületi hibahelyekhez lehet kapcsolni. Az emissziós spektrumokon látszik, hogy az UV tartományban jelentkező csúcs minden minta esetében 390 nm-nél jelentkezik, közel azonos intenzitással, míg a látható tartományban lévő csúcs esetében eltérés van a különböző részecskék esetén mind intenzitásban, mind a maximum helyében. 
Megállapítottam, hogy az összefüggést nem a részecskeméret, hanem a primer kristályok méretének figyelembe vételével kell keresni. Ábrázoltam a különböző méretü részecskék esetében tapasztalt emissziós maximum helyét illetve az emissziós intenzitást az őket alkotó primer kristályok méretének függvényében (58. ábra, d drimer értékek lásd 4. táblázat).

a)

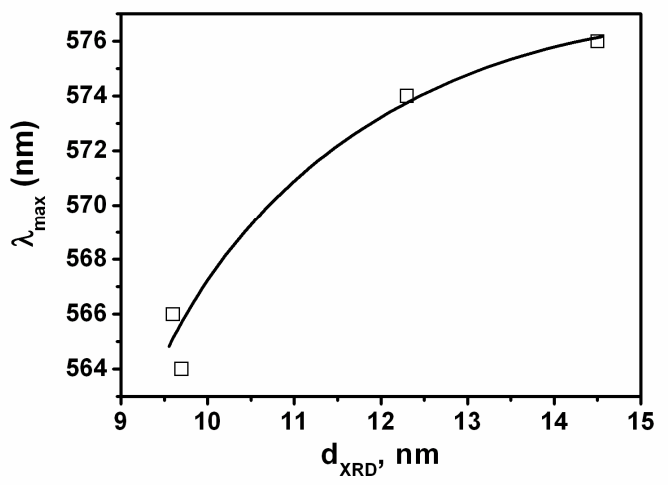

b)

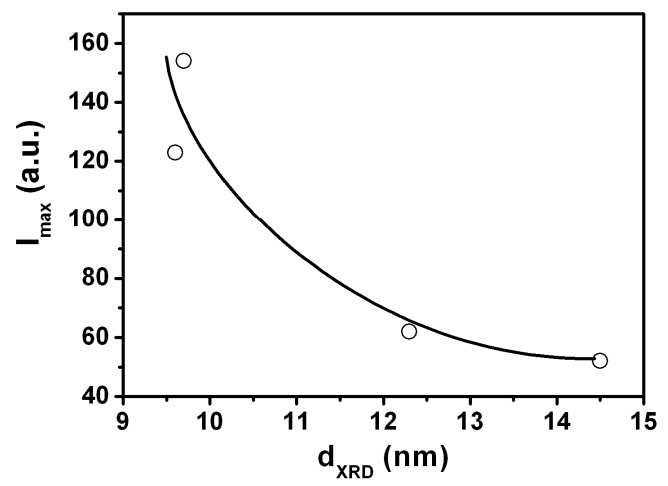

58. ábra. Az emissziós maximum a) helyének és b) intenzitásának függése a primer krisztallitok méretétől a különböző méretű részecskék esetén.

Látható, hogy a primer krisztallitok méretének növekedésével az emissziós maximum a nagyobb hullámhosszak felé tolódik, az intenzitás pedig csökken.

$\mathrm{Az}$ eredmények értékelésekor figyelembe kell venni a filmek fotonikus kristály szerkezetét. A fotonikus kristályokban csökken az emissziós intenzitás, ha a tiltott sáv és az emissziós sáv átfednek, ugyanis a tiltott sávnak megfelelő energiájú fényhullámok terjedése a filmben nem megengedett [146]. Ismert, hogy a fotonikus kristályokban a tiltott sáv helye függ a megfigyelési szögtől a korábban bemutatott (20) és (21) egyenletek alapján.

9. táblázat. A fluoreszcencia emisszió detektálási szögének $\left(\gamma=60^{\circ}\right)$ megfelelő fotonikus tiltott sávok helyzete a (20) és (21) egyenletek alapján.

\begin{tabular}{llll}
\hline $\mathrm{ZnO}$ & $\mathbf{3 0 1} \mathbf{n m}$ & $\mathbf{3 4 9} \mathbf{n m}$ & $\mathbf{4 5 7} \mathbf{n m}$ \\
\hline$\lambda_{\max , \mathbf{I}}\left(\boldsymbol{\gamma}=\mathbf{6 0}^{\circ}\right), \mathbf{n m}$ & 594 & 651 & 842 \\
$\lambda_{\max , 2}\left(\boldsymbol{\gamma}=\mathbf{6 0}^{\circ}\right), \mathbf{n m}$ & 297 & 326 & 421 \\
\hline
\end{tabular}

A fluoreszcencia mérések esetében a detektálás szöge a felületi normálhoz képest $60^{\circ}$, ezért ki kell számolni, hogy ezen szög alatt hová tolódik a tiltott sáv. Az első és másodrendű tiltott sávok helyeit a $\gamma=60^{\circ}$ esetén a 9. táblázat tartalmazza. Látható, hogy 


\section{Eredmények II. rész 80 \\ 200-500 nm-es cink-oxid részecskék és filmjeik}

egyik tiltott sáv sem fed át jelentős mértékben az emissziós sávval, kivéve a 301 nm-es részecskék filmjének elsőrendü esetét. A 57. ábra tanúsága szerint a 301 nm-es részecskék filmje mutatja a leggyengébb emissziót. Az elsőrendủ tiltott sáv azonban meglehetősen kismértékü tiltást jelent, ezért valószínűleg inkább a részecskeméret hatásának tulajdonítható a gyenge emisszió. 


\section{VI.5 Mintázott felületek előállítása 341 nm-es ZnO részecskékkel}

\section{VI.5.1 Mintázatképzési paraméterek optimalizálása}

A $\mathrm{ZnO}$ részecskék önszervező módon mintázatokba történő rendeződését számos paraméter befolyásolja. A részecskék, a hordozó és a bélyegző felületi tulajdonsága mellett fontos a részecskék koncentrációja, stabilitása a vizes közegü szoljaikban, valamint a bélyegző felszínét jellemző hullámhossz is, tehát a megfelelő rendezettségi szint elérése nem könnyü feladat.

A kísérletekhez használt $341 \mathrm{~nm}$-es $\mathrm{ZnO}$ részecskéket dietilénglikolos közegben szintetizáltam, a mintázatképzéshez azonban vizes közegbe kellett őket átvinnem. A részecskék vizes közegben kevésbé stabilak: a közegcsere után nagyjából 1 napig individuális részecskék vannak a szolban, azután azonban megjelennek néhány részecskéből álló aggregátumok, de nagymértékü aggregáció még hónapok elteltével sem tapasztalható. Zeta potenciál mérések során tapasztalt $21 \mathrm{mV}$-os átlagérték is a szol gyengébb stabilitását támasztja alá.

Mintázatképzési elökísérleteket végeztem különböző koncentrációjú (0,5mg/ml $10 \mathrm{mg} / \mathrm{ml}$ ) szolokkal, mely során megállapítottam, hogy az $5 \mathrm{mg} / \mathrm{ml}-10 \mathrm{mg} / \mathrm{ml}$ koncentráció tartomány használható eredményesen, ezért a későbbiekben az eredeti koncentrációt használtam.

A bélyegző hullámhosszának megválasztását a részecskék méretéhez kell igazítani, a hullámhossz szabályozása pedig az oxigén plazma kezelés idejével történik. A hosszabb kezelés során a bélyegző felszínén vastagabb réteg oxidálódik, amely a relaxálás során nagyobb hullámhosszat eredményez. Különböző ideig (5, 10, 20, 40 és 60 perc) tartó oxigén plazma kezeléssel hullámosított bélyegzőkkel végzett előkísérleteim alapján a 20 perces kezelésnek alávetett PDMS felszínt találtam legalkalmasabbank a 341 nm-es ZnO részecskékhez a legmegfelelöbb.

A részecskék, a hordozó és a bélyegző felszínének módosítása során a IV.3.3 fejezetben leírt anyagokat és módszereket használtam. Kísérleteket végeztem módosítatlan, perkénsav oldatban megtisztított üveglappal, amelynek felszíne negatív töltésủ. A felület módosítására többféle anyagot használtam. A szilanizáló szer (APTES) kémiailag kötődik 
a felszínhez és pozitív töltésủ felületet eredményez. A poli-L-lizin-polietilénglikol (PLL-gPEG) kopolimer a poli-L-lizin résszel elektrosztatikus vonzó kölcsönhatással kapcsolódik az üveg felszínhez, a polietilénglikol oldalláncok révén pedig semleges töltésü, hidrofil jellegü felszínt kaptam. A polietilénimin (PEI) pozitív töltésű polielektrolit szintén elektrosztatikus kölcsönhatások révén kötődik a negatív töltésü üveg felszínéhez erőteljesen áttöltve azt.

A pozitív felületi töltésü $\mathrm{ZnO}$ részecskék felületére negatív töltésü polieletrolitokat (PAA és PSS) adszorbeáltattam, amelynek hatására a felületük áttöltődött. A módosítatlan és a polielektrolittal borított részecskék zeta potenciáljának mérésével megbizonyosodtam az áttöltésről valamint a mérések igazolták a szol stabilitását is (10. táblázat).

10. táblázat. A $341 \mathrm{~nm}$-es $\mathrm{ZnO}$ részecskék felületének polielektrolitokkal való borítását jellemző

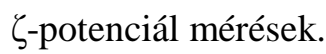

\begin{tabular}{cccc}
\hline & ZnO & ZnO-PAA & ZnO-PSS \\
\hline$\zeta(\mathbf{m V})$ & $20,8 \pm 6,1$ & $-43,8 \pm 5,4$ & $-40,9 \pm 4,9$ \\
\hline
\end{tabular}

A részecskék, a hordozó és a bélyegző felületi tulajdonságainak a részecskék önszerveződésére való hatását nagyszámú kísérlettel teszteltem. Az egyes kísérletek során használt hordozó-részecske-bélyegző kombinációkat a 11. táblázatban tüntettem fel.

11. táblázat. A mintázatképzés paramétereinek optimalizálása során alkalmazott hordozórészecske-bélyegző kombinációk.

\begin{tabular}{cccc}
\hline Hordozó & Részecskék & Bélyegző & Eredmény \\
\hline tiszta üveglap & $\mathrm{ZnO}$ & hidrofób & - \\
\hline PLL-g-PEG & $\mathrm{ZnO}$ & hidrofób & - \\
APTES & $\mathrm{ZnO}$ & hidrofób & - \\
PEI $_{\text {LMW }}$ & $\mathrm{ZnO}$ & hidrofób & ++ \\
PEI $_{\text {HMw }}$ & $\mathrm{ZnO}$ & hidrofób & + \\
tiszta üveglap & ZnO-PAA & hidrofób & - \\
\hline PLL-g-PEG & ZnO-PAA & hidrofób & - \\
\hline PEI HMw & ZnO-PAA & hidrofób & - \\
tiszta üveglap & ZnO-PAA & hidrofil & - \\
\hline tiszta üveglap & ZnO-PSS & hidrofób & - \\
PLL-g-PEG & ZnO-PSS & hidrofób & - \\
tiszta üveglap & ZnO-PSS & hidrofil & - \\
\hline
\end{tabular}


Az eredmények alapján a következő megállapításokra jutottam.

- A módosítatlan $\mathrm{ZnO}$ részecskék (pozitív felületi töltés) a tiszta üveglapra (negatív felületi töltés) ülepedés után helyváltoztatás nélkül elektrosztatikus kölcsönhatások következtében adszorbeálódnak, így a hullámos felszínű bélyegző nem tudja irányítani a részecskék rendeződését a folyadék elpárolgása közben. Tehát az önrendeződés szempontjából kívánatos az azonos felületi töltés.

- A PLL-g-PEG-gel borított üveglap nem volt elég hidrofil, így a részecskék száradás közben a mozgó folyadékmeniszkuszal együtt hátráltak ki a bélyegző alól.

- A hidrofil felszínü bélyegző negatív felületi töltésü, amelyre a módosítatlan részecskék jelentős mértékben adszorbeálódtak, megakadályozva ezzel az irányított önrendeződést.

- A PSS-sel és a PAA-val borított $\mathrm{ZnO}$ részecskék egyetlen esetben sem mutattak rendezettséget.

- Sikeres volt a mintázatképzés, amikor a hordozó felszínét PEI-vel borítottam, módosítatlan részecskéket alkalmaztam hidrofób felszínü bélyegzővel. Jelentős különbség mutatkozott azonban a kis- és a nagy molekulatömegü PEI között (59. ábra). A nagy molekulatömegü PEI-vel ( $\left.\mathrm{PEI}_{\mathrm{HMW}}\right)$ is elérhető bizonyos fokú rendezettség, de a hordozón láthatók nagyobb részecskeaggregátumok, amelyek a hordozó és a bélyegző között távtartóként működve megakadályozták az úgynevezett bezárt tér általi irányítást. A kis molekulatömegü PEI-vel ( $\left.\mathrm{PEI}_{\mathrm{LMW}}\right)$ nem tapasztalható a részecskék aggregációja a felszínen, így rendezett mintázatokat kaptam. Meg kell jegyeznem, hogy a rendezettség azonban még nem tökéletes, de sikerült elérni a hullámos felszínü bélyegzőnek megfelelö sávos rendezettséget.
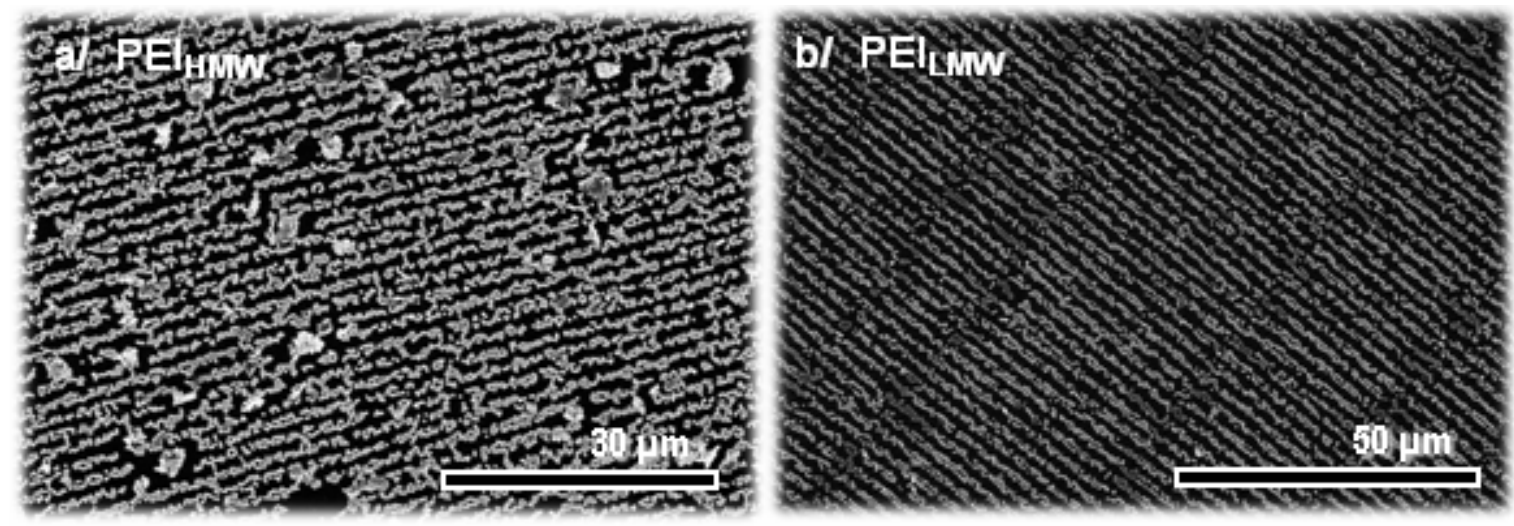

59. ábra. Az üveglap felületének borítására használt PEI molekulatömegének hatása a létrehozott mintázatok rendezettségére: a) nagy molekulatömegü PEI ( $\left.\mathrm{PEI}_{\mathrm{HMW}}\right)$ és

b) kis molekulatömegü PEI ( $\left.\mathrm{PEI}_{\mathrm{LMW}}\right)$.

(Mindkét esetben módosítatlan $\mathrm{ZnO}$ részecskéket és hidrofób felszínủ bélyegzőket alkalmaztam.) 
Kísérleteim során eredeti célom az volt, hogy a hullámos felszín által kialakított részecskesor mindössze egyetlen részecske szélességü legyen, itt azonban ennek a többszöröse látható. Ezt a célt nem sikerült elérnem, mindössze egy kis területen találtam meg a várt struktúrát (60. ábra).

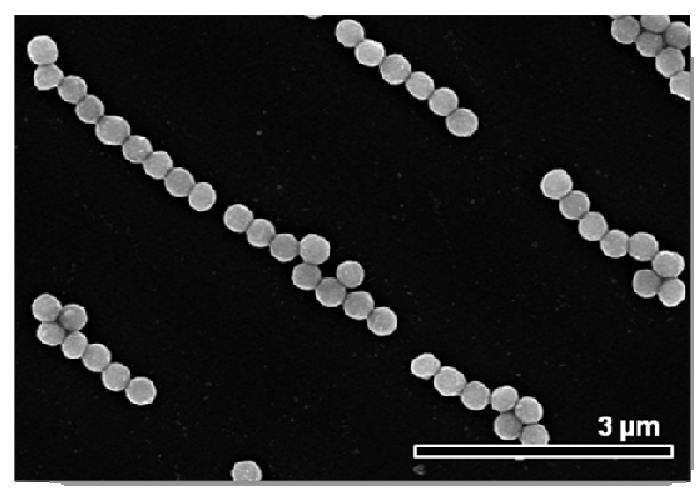

60. ábra. Egyetlen részecske szélességủ részecskesor.

\section{VI.5.2 ZnO részecskék mintázatainak jellemzése}

A mintázott filmek sajátságainak vizsgálatához, a rendezettség hatásának pontos megismeréséhez olyan filmeket is készítettem, ahol a részecskék szabálytalanul, random szerkezetben helyezkednek el a hordozón (IV.3.4. alfejezet). A mintázatok különböző tulajdonságait a random szerkezetü filmekkel összehasonlítva fogom tárgyalni.

A mintázott és random szerkezetű filmekben a részecskék rendezettségének jellemzésére SEM felvételeket készítettem (61. ábra). Jól látszik a részecskék sávos elrendeződése, a hullámos felszínű bélyegző által irányított önrendeződés. A nagyított kép jól mutatja, hogy a részecskék csak a bélyegző által meghatározott sávban helyezkednek el, a sávon belül azonban nem alakult ki rendezettség. Ennek oka az lehet, hogy a részecskék a méretüknél jóval szélesebb (2-3-szoros) sávokba rendeződtek, a sávon belül viszont a száradás során mozgó folyadékmeniszkusz mentén a kapilláris erők irányítják a részecskék mozgását. Ismert, hogy mozgó folyadékmeniszkusznál ható kapilláris erők képesek a részecskék szabályos struktúrákba történő rendezésére, de jelen esetben ez nem valósult meg. Az eredmények ismeretében újból kísérleteket végeztem kisebb hullámhosszú PDMS bélyegzőkkel is, azonban nem sikerült a mintázatképzés. Megfigyelhető azonban, hogy az Au felszínen kialakított sávokban valamivel tömörebben illeszkednek a részecskék. 

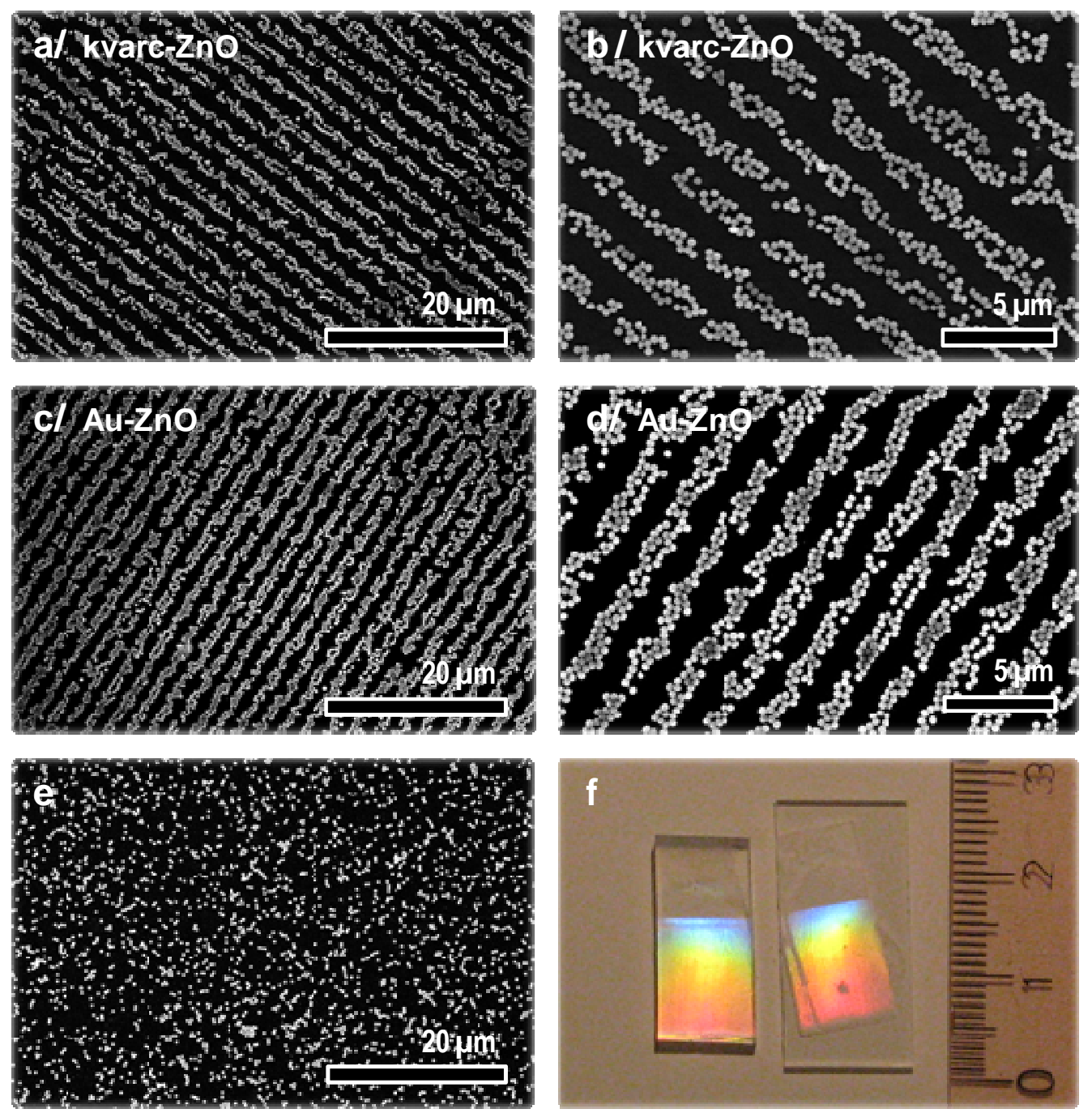

61. ábra. A ZnO részecskék mintázatainak és random szerkezetü filmjeinek rendezettségét, struktúráját bemutató felvételek. a-b) kvarchordozón, illetve c-d) Au-val borított hordozón létrehozott mintázatok, e) random szerkezetű film SEM képe, f) a ZnO mintázatról és a hozzá tartozó bélyegzőröl készült fénykép.

A SEM felvételek alapján meghatároztam a mintázatot jellemző periodicitást, azaz a hullámhosszat; a 12. táblázatban foglaltam össze a kapott értékeket. A kvarchordozón 2,44 $\mu \mathrm{m}$, az arannyal bevont hordozón pedig 2,14 $\mu \mathrm{m}$ átlagos értékeket határoztam meg. A különbség oka, hogy a két mintázathoz különböző bélyegzőket használtam. Ezek a bélyegzők - habár előállításuk azonos körülmények közt történt - felszínükön mégsem teljesen azonos paraméterekkel (hullámhossz, amplitúdó) jellemezhető hullámok képződtek. 
12. táblázat. A kvarc- és Au-val bevont üveghordozókon elóállított mintázatok periodicitása pásztázó elektronmikroszkópos és lézerdiffrakciós mérések alapján.

\begin{tabular}{llcccc}
\hline & SEM & \multicolumn{2}{c}{$\begin{array}{c}\text { Lézerdiffrakció } \\
(\mathbf{5 3 2} \mathbf{~} \mathbf{m})\end{array}$} & \multicolumn{2}{c}{$\begin{array}{c}\text { Lézerdiffrakció } \\
(\mathbf{6 7 0} \mathbf{~ n m})\end{array}$} \\
& & I. rend & II. rend & I. rend & II. rend \\
\hline kvarc/ZnO & $2,44 \pm 0,15$ & $2,50 \pm 0,2$ & $2,27 \pm 0,2$ & $2,46 \pm 0,2$ & $2,29 \pm 0,2$ \\
üveg/Au/ZnO & $2,14 \pm 0,16$ & $2,18 \pm 0,2$ & $2,10 \pm 0,2$ & $2,19 \pm 0,2$ & $2,00 \pm 0,2$ \\
\hline
\end{tabular}

A rendezettség következtében a mintázatok a diffrakció jelenségét mutatják olyan fénnyel, amelynek a hullámhossza egy nagyságrendben van a periodicitásukkal. Különböző hullámhosszúságú lézerforrásokkal $(532 \pm 10 \mathrm{~nm}$ és $670 \pm 10 \mathrm{~nm})$ végeztem kísérleteket, az első- és másodrendü reflexiók jól láthatók, a harmadrendü reflexiók azonban már meglehetősen homályosak (62. ábra).

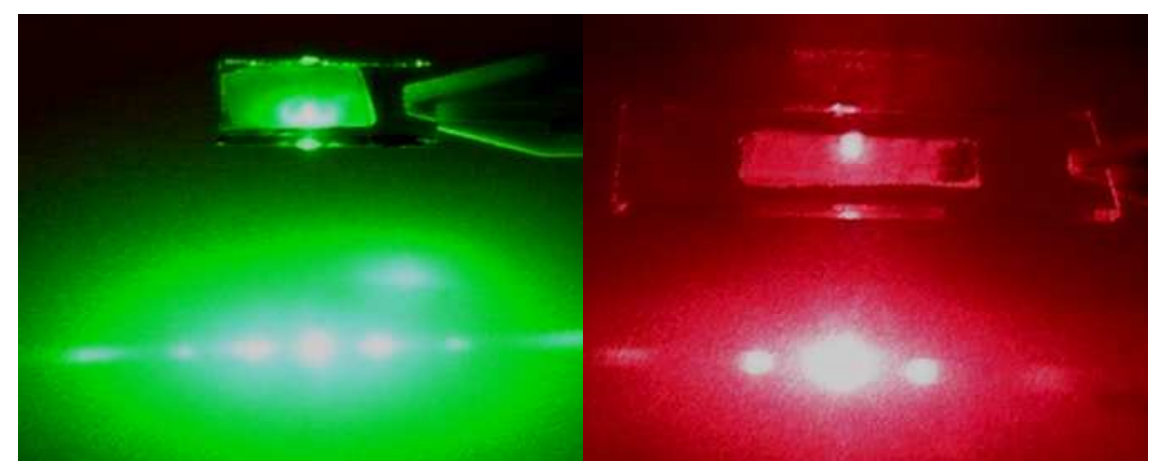

62. ábra. A zöld $(532 \pm 10 \mathrm{~nm})$ és piros $(670 \pm 10 \mathrm{~nm})$ lézerforrásokkal látható diffrakciós foltok: az első- és másodrendủ reflexiók jól láthatók. (A valóságban élesebben elkülönül a diffrakciós folt a szórt fénytől, mint ahogyan azt a fénykép visszaadja.)

A diffrakciós foltok helye alapján a (9) egyenlet segítségével meghatároztam a mintázatok hullámhosszát (12. táblázat). Az adatokból kitűnik, hogy az elsőrendű elhajlások alapján kapott értékek jó egyezést mutatnak a SEM képekből meghatározottakkal. A másodrendü foltok alapján számolt értékek az előzőeknél szignifikánsan kisebb periodicitást mutatnak.

A lézerdiffrakciós kísérletek során a mérési körülmények lehetővé tették, hogy egyszerüen ellenőrizzem a mintázat periodicitásának homogenitását. A vizsgálat során a hordozó mozgatásával és a diffrakciós mintázat egyidejü megfigyelésével megállapítottam, hogy a hullámhossz eloszlása nem homogén, a mintázat alsó részén (61. ábra f) része) a 
legkisebb a hullámhossz, az ábra szerinti elrendezésben felfelé haladva pedig növekszik. Ez természetesen a bélyegző inhomogenitásának tükre, feltehetően a hullámosítás során a megnyújtott állapotú PDMS csíkban kialakuló inhomogén feszültségeloszlás következménye.

A mintázott filmek optikai tulajdonságainak jellemzésére UV-Vis transzmittancia spektrumokat mértem. A részecskék elrendeződésének hatását jól szemlélteti a 63. ábra, amelyen a $341 \mathrm{~nm}$-es $\mathrm{ZnO}$ részecskékből felépített mintázat, Langmuir-Blodgett-film és a random szerkezetü film spektrumait ábrázoltam.

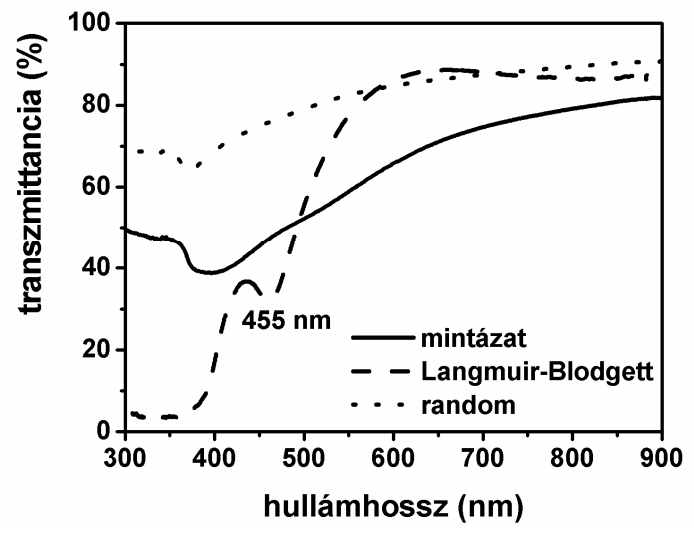

63. ábra. A $341 \mathrm{~nm}$-es $\mathrm{ZnO}$ részecskék kvarchordozós filmjeinek UV-Vis transzmittancia spektrumai: mintázat, Langmuir-Blodgett-film és szabálytalan struktúra.

A mintázat és a random szerkezetű film hasonló lefutású spektrumot ad, a transzmittancia a hullámhossz csökkenésével a ZnO elnyelése, valamint fényszóródás következtében csökken, a részecskék elnyelési maximuma 370 nm körül van. A LangmuirBlodgett-film az előbbiektől eltérő viselkedést mutat: a szoros, hexagonális illeszkedésben elrendezett részecskék filmjének transzmittancia spektrumán 455 nm-nél megjelenik a fotonikus kristályokra jellemző tiltott sáv (,fotonikus band gap”).

A mintázatokba rendezett $\mathrm{ZnO}$ részecskék fluoreszcencia emissziós sajátságait tanulmányoztam kvarc- és $50 \mathrm{~nm}$-es aranyréteggel bevont üveghordozókon (64. ábra). Megállapítottam, hogy mind a random, mind a rendezett filmek esetén erősödik az emisszió az aranybevonat jelenlétében, de jelentős különbség az erősítésben nincsen. Mindkét esetben tapasztalható a hullámhossz eltolódása a plazmonikus kölcsönhatás következtében; a mintázatok esetében valamivel nagyobb, $11 \mathrm{~nm}$ eltolódást mértem. További eltérés az UV emisszió hullámhosszában mutatkozik: a random szerkezetű filmeknél az UV emisszió maximuma 393 nm-nél található, míg a mintázatok esetében ez 
a csúcs 383-384 nm-nél jelentkezik. Ennek egy lehetséges magarázata lehet a részecskék átlagos távolságának különbsége a hordozón.
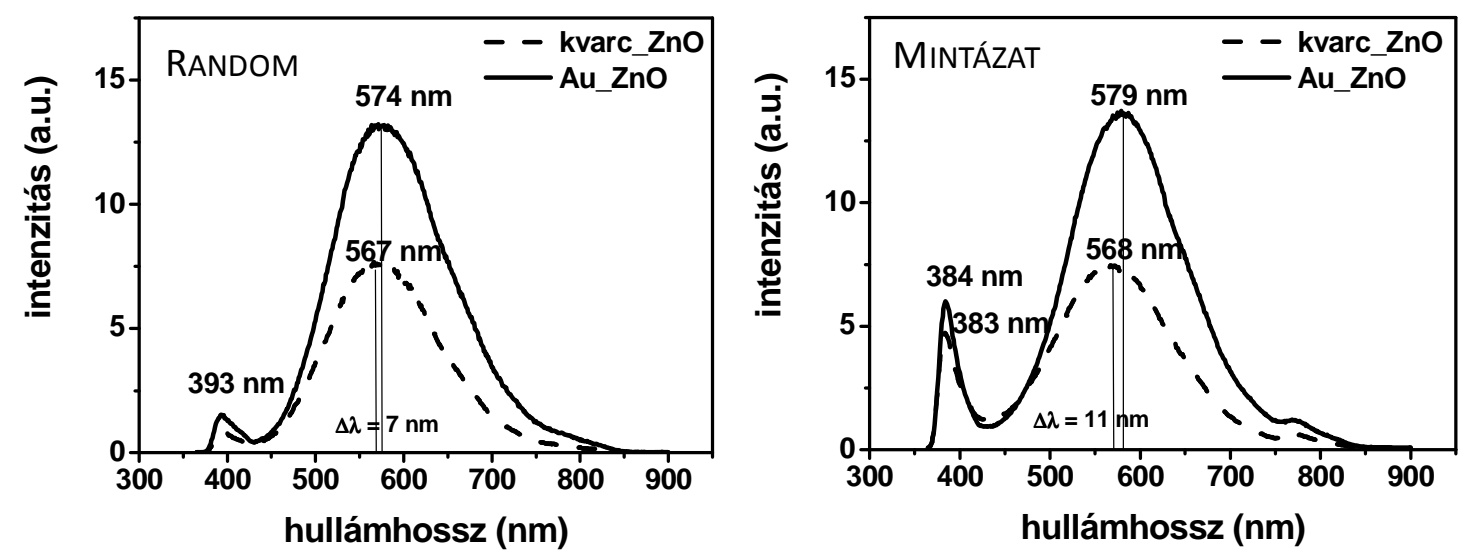

64. ábra. A kvarc- és aranybevonatú üveghordozókon a random szerkezetủ filmek és a mintázatok esetén mért fluoreszcencia emissziós spektrumok. 


\section{VII. ÖSSZEFOGLALÁS}

Munkám során $\mathrm{ZnO}$ nanorészecskék szintézisével (kétféle eljárással), jellemzésével foglalkoztam, majd belölük víz/levegő határfelületen Langmuir-filmeket és ezek szilárd hordozóra történő átvitelével Langmuir-Blodgett-filmeket állítottam elő, valamint templát által irányított önszerveződéses elven sávos mintázatokat hoztam létre.

$\mathrm{Az}$ etanolos közegben szintetizált 3-7 nm-es $\mathrm{ZnO}$ részecskék Ostwald-féle öregedését jellemeztem UV-Vis abszorbancia, röntgendiffrakciós és dinamikus fényszórás mérésekkel. Megállapítottam, hogy szobahőmérsékleten a részecskék mérete a szintézist követően tovább nő, nagyjából $7 \mathrm{~nm}$-es maximális méret eléréséig. A szolok stabilitásának növelésére alacsony hőmérsékletü tárolást és polietilénimin felületmódosító ágenst alkalmaztam. A részecskék méretének növekedését kihasználva jellemeztem azok méretfüggő fluoreszcencia emissziós sajátságaikat. A részecskék méretének növekedésével a látható emissziós maximum a nagyobb hullámhosszak felé tolódik el, az emisszió intenzitása pedig ezzel párhuzamosan csökken. A 3-7 nm-es ZnO részecskék vízfelszíni Langmuir-filmjeinek tanulmányozása során oldalnyomás vs. terület izotermák mérésén keresztül megmutattam, hogy a mind a $\mathrm{ZnO}$, mind a polietiléniminnel borított $\mathrm{ZnO}$ részecskékből stabil, szilárd hordozóra átvihető filmek alakíthatók ki. A polietiléniminnel borított részecskék egy része a filmképzési eljárás során a szubfázis felé elhagyja a határfelületet, azonban az átiveli folyamatot ez nem hátráltatja. Megmutattam a hordozós Langmuir-Blodgett-filmek lineáris felépülését UV-Vis abszorbancia spektrumokkal, a filmek szerkezetét atomerő mikroszkópos képekkel jellemeztem, valamint a filmek fluoreszcencia emissziós vizsgálata során rámutattam, hogy a részecskék a filmben megőrzik emissziós sajátságukat.

A 3-7 nm-es ZnO részecskék fluoreszcencia emisszós sajátságainak módosítására aranybevonatú hordozókra készítettem el a Langmuir-Blodgett-filmjeiket. Két különböző módszerrel készített aranybevonattal ellátott hordozóval terveztem kísérleteket, amelyek során rámutattam az arany nanostrukturáltságának fontos szerepére. Az arany és a ZnO közti távolság finom hangolására sztearinsavból távtartó rétegeket építettem a nemesfém és a félvezető közé szintén a Langmuir-Blodgett technikával. Fluoreszcencia emissziós méréseken keresztül megmutattam az $\mathrm{Au}$ és a $\mathrm{ZnO}$ részecskék közötti plazmonikus 
kölcsönhatás jelentőségét az emissziós sajátságokra a kettő közti távolság és az arany morfológiájának függvényében.

A 200-500 nm méretü, monodiszperz, gömb alakú ZnO részecskék szintézisét autoklávban valósítottam meg dietilén-glikolos közegben. A részecskék méretét, méreteloszlását transzmissziós elektronmikroszkópos felvételek alapján határoztam meg, a morfológia és az aggregációs típusú növekedési mechanizmus jellemzésére pásztázó elektronmikroszkópos felvételek készültek. A részecskék fajlagos felületét, sürüségét és porozitását $\mathrm{N}_{2}$ adszorpciós-deszorpciós mérésekböl határoztam meg, röntgendiffrakciós mérések készültek a részecskék kristályosságának jellemzésére és a primer részecskeméret meghatározására. Langmuir-mérlegben víz/levegő határfelületen előállítottam a részecskék Langmuir-filmjét és oldalnyomás-terület izotermákkal jellemeztem azokat. A szilárd hordozós Langmuir-Blodgett-filmek szerkezetét pásztázó elektronmikroszkópos képekkel jellemeztem. Az optikai tulajdonságok vizsgálatához felvettem a filmek transzmittancia és reflektancia spektrumait. Egy megfelelő optikai modell meghatározása után (figyelembe véve a film szabályos, hexagonális szerkezetét) számított görbéket illesztettem a mért reflektancia spektrumokra, amelyekből azután meghatároztam a filmek vastagságát, törésmutatóját és a részecskék tömörségét a filmben. A Langmuir-Blodgett-filmek transzmittancia spektrumain részecskemérettől függő helyen megjelenik a fotonikus kristályokra jellemző tiltott sáv (ún. „band gap”), amelyből számolással következtettem a film szerkezetére. A filmeket jellemeztem fluorszcencia emissziós mérésekkel is, megállapítottam, hogy a részecskéket felépítő primer kristályok mérete határozza meg az emissziós maximum helyét.

A $341 \mathrm{~nm}$ átméröjü monodiszperz, gömb alakú $\mathrm{ZnO}$ részecskék felhasználásával nanoszerkezetű mintázatok előállítását tűztem ki célul. A sávos mintázatok kialakítására templátként oxigén plazmában előállított hullámos felszínü PDMS (polidimetilsziloxán) bélyegzőket alkalmaztam, amelyeknél a csatornák szélessége és mélysége a plazmakezelés paramétereinek változtatásával széles tartományban hangolható. A mintázatképzés paramétereinek optimalizálása során különböző felületmódosító ágenseket alkalmaztam mind a részecskék, mind a filmek felületi tulajdonságainak változtatására. A megfelelő rendezettség elérése után a filmeket UV-Vis transzmittancia és fluoreszcencia emissziós mérésekkel jellemeztem. Kimutattam, hogy a mintázatokba rendezett $\mathrm{ZnO}$ részecskék fluoreszcencia emissziós tulajdonságai is befolyásolhatók fém jelenlétében létrejövő plazmonikus kölcsönhatások következtében. 


\section{SUMMARY}

During my work I have synthesized $\mathrm{ZnO}$ particles with two different methods. I have prepared their Langmuir-films at the air/water interface, Langmuir-Blodgett-films on different solid substrates and patterned assemblies on quartz in order to study the optical and photoluminescence properties of these ordered structures.

The $\mathbf{Z n O}$ particles in the size range of 3-7 $\mathbf{~ n m}$ were synthesized in ethanolic media, UV-Vis absorbance, dynamic light scattering and x-ray diffraction methods were used to describe the Ostwald ripening process undergoing after synthesis. I have found that that the average particle size increases from $3 \mathrm{~nm}$ to about $7 \mathrm{~nm}$ and the band gap energy decreases to the bulk band gap of $\mathrm{ZnO}$ in a 10 day period. I have applied low temperature storage and steric stabilizer polyelectrolite (polyethyleneimine) for inhibition of particle growth. I have studied the photoluminescence emission property of the particles as a funtion of their size. Size-dependent emisson was observed for both the UV and the visible emission of the particles: the emission maxima is shifted to the higher wavelengths and the intensity is decreasing when particle size increases. The difference between the lowest and the highest maxima is about $30 \mathrm{~nm}$.

Study of the Langmuir-films of the $\mathrm{ZnO}$ and polyethyleneimine coated $\mathrm{ZnO}$ particles with average size in the 3-7 $\mathrm{nm}$ region was performed with the measurement of surface pressure vs. surface area isotherms. I have shown that the small fraction of the polyelectrolite coated particles are lost during spreading and compression due to the good hydration properties of polyethyleneimine in water, although it is possible to obtain stable films which can be transfered onto solid substrates. The linear built up of the films was proven by UV-Vis absorbance measurements, the sturcture of multilayered films was characterized by atomic force microscopic images. Fluorescence emission study of the Langmuir-Blodgett-films of these particles revealed that particles preserve their emission properties in the solid supported films.

Gold coated substrates were also used for supported films of $\mathrm{ZnO}$ in order to modify the emission properties due to plasmonic interaction with gold. I have used two different types of Au coatings to study the effect of the structure of $\mathrm{Au}$. I have inserted stearic acid Langmuir-Blodgett layers between the metal and the semiconductor for fine tuning their distance. Fluorescence emission measurements revealed the distance- 
dependent plasmonic interaction of $\mathrm{ZnO}$ and $\mathrm{Au}$, additionally large 12-fold enhancement was observed at $2.2 \mathrm{~nm}$ distance.

Monodispersed, spherical $\mathrm{ZnO}$ particles in the size range of $\mathbf{2 0 0 - 5 0 0} \mathbf{n m}$ were synthesized in diethylene glycol media. I have determined the size and size-distribution of the particles based on transmission images and demonstrated the aggregation type growth mechanism with scanning electronmicroscopic images. Nitrogen adsorption and desorption measurements were performed to calculate the surface area, density and porosity of the particles. X-ray diffraction measurements revealed the crystallinity of the particles, additionally Scherrer equation was used to determine the primary cristallite size.

Langmuir-films at the air/water interface were formed with the monodispersed $\mathrm{ZnO}$ particles in the size range of 200-500 nm. Evaluation of the measured surface pressure vs. surface area isotherms showed that the particles form stable, hexagonally close packed order on the water surface. I have prepared single and multilayered Langmuir-Blodgettfilms of $\mathrm{ZnO}$ particles and I was focusing on the optical and photoluminescence properties. Scanning electronmicroscopic images showed well ordered, hexagonal arrays of particles. Transmittance spectra of the films showed the photonic crystal structure, first and second order photonic band positions were identified. Reflectance spectra were measured and fitted with an appropriate optical model which considered the special particle arrangement. The parameters of the optical model assigned effective refractive index, film thickness and average particle-particle distance in the film. Photoluminescence emission measurements showed intense a visible and a weaker UV emission of the films. I have found that the position of the visible emission maxima is determined by the primary crystallite size of the particles.

$\mathrm{ZnO}$ particles with $341 \mathrm{~nm}$ average diameter were also used for template assisted surface patterning. PDMS (polydimethylsiloxane) stripes with wrinkled surface were used as templates to obtain grating-like structures. Optimal parameters for particle assembly were found in case of hyrdophobic PDMS stamps, low molecular weight polyethyleneimine coating on the substrate and uncoated $\mathrm{ZnO}$ particles. I have characterized the patterned $\mathrm{ZnO}$ assemblies by optical and photoluminescence measurements. UV-Vis transmittance showed no specific feature, it was found to be similar to random structued films. Fluorescence emission measurements showed that the photoemission properties of patterned $\mathrm{ZnO}$ can be modified with gold coating on the substrate due to plasmonic interactions. 


\section{KÖSZÖNETNYILVÁNÍTÁS}

Köszönetet mondok témavezetőmnek, Dr. Dékány Imrének, amiért lehetővé tette számomra, hogy a csoportjában dolgozhassak. Köszönöm, hogy munkám során mindvégig támogatta szakmai fejlődésemet minden téren: a számos inspriáló konzultációt, amely során sokat tanultam és rengeteg ötletet kaptam, a konferencia részvételeket, ahol az érdekes és hasznos előadások meghallgatása mellett saját eredményeimet is bemutathattam, valamint a külföldi tanulámnyutat, ahol rengeteg új tapasztalatot szereztem.

Köszönetet mondok Dr. Erdőhelyi András tanszékvezető egyetemi tanárnak, amiért lehetővé tette munkámat a Fizikai Kémiai és Anyagtudományi Tanszéken.

Köszönettel tartozom Dr. Sebők Dánielnek, Juhászné Dr. Csapó Editnek, Králikné Benkő Máriának, Tóth Ildikónak, Varga Viktóriának, Lagdánné Szélpál Évának, Ráczné Kuhn Klárának, Veres Ágnesnek, Dr. Szabó Tamásnak, Dr. Kőrösi Lászlónak, Kőrösiné Dr. Papp Szilviának és a Fizikai Kémiai és Anyagtudományi Tanszék Kolloidok és Nanoszerkezetü Anyagok Csoport jelenlegi és korábbi munkatársainak a barátságukért és a munkám során nyújtott számos elméleti és gyakorlati segítségükért.

Köszönetemet fejezem ki bayreuthi munkatársaimnak, Andreas Fery Professzornak, Christoph Hanskenak és Mareen Müllernek.

Végül, de nem utolsó sorban szeretném megköszönni férjemnek és a családomnak, hogy mindvégig támogattak és minden feltételt biztosítottak a doktori munkám elkészítéséhez. 


\section{TUDOMÁNYOS KÖZLEMÉNYEK}

\section{Az értekezés témájában született dolgozatok:}

1. N. Ábrahám, I. Dékány

Size-dependent photoluminescence properties of bare $\mathrm{ZnO}$ and polyethylene imine stabilized $\mathrm{ZnO}$ nanoparticles and their Langmuir-Blodgett films

Colloid. Surf. A.: Physicochem. Eng. Aspects, 364 (2010) 26-33.

2. N. Ábrahám, D. Sebők, Sz. Papp, L. Kőrösi, I. Dékány

IF $_{2010}: \mathbf{2 , 1 3 0}$

Two dimensional arrangement of monodisperse $\mathrm{ZnO}$ particles with Langmuir-Blodgett technique

Colloid. Surf. A.: Physicochem. Eng. Aspects, 384 (2011) 80-89.

3. N. Ábrahám, I. Dékány:

$\mathrm{IF}_{2011}: \mathbf{2 , 2 3 6}$

Enhanced photoluminescence of $\mathrm{ZnO}$ Langmuir-Blodgett films on gold coated substrates by plasmonic coupling

J. Phys Chem C, 116 (29), pp 15667-15674.

4. N. Ábrahám, C. Hanske, M. Müller, A. Fery, I. Dékány

$\mathrm{IF}_{2011}: \mathbf{4 , 8 0 5}$

Patterned assemblies of $\mathrm{ZnO}$ particles on gold

szerkesztés alatt

IF: -

$\Sigma$ IF: 9,171

\section{Az értekezés témájához részben kapcsolódó dolgozatok:}

5. E. Hild, A. Deák, L. Naszályi, Ö. Sepsi, N. Ábrahám, Z. Hórvölgyi

Use of the optical admittance function to stimulate and evaluate transmittance spectra of graded-index colloidal films

J. Optics A: Pure and Appiled Optics 9 (2007) 920-930.

IF $_{2007}: \mathbf{1 , 7 5 2}$

6. L. Naszályi Nagy, N. Ábrahám, E. Hild, D. Cot, A. Ayral, Z. Hórvölgyi

Complex Langmuir-Blodgett films of $\mathrm{SiO}_{2}$ and $\mathrm{ZnO}$ nanoparticles with advantageous optical and photocatalytical properties

Langmuir 24 (2008) 12575-12580.

IF $_{2008}: 4,097$

7. L. Naszályi Nagy, N. Ábrahám, E. Hild, A. L. Kovács, A. van der Lee, V. Rouessac, D. Cot, A. Ayral, Z. Hórvölgyi

Zinc oxide LB films with improved antireflective, photocatalytic and mechanical properties Progr Colloid Polym Sci 135 (2008) 107-118.

IF $_{2008}: 1,736$ 


\section{Konferenciaszereplések / előadások:}

1. N. Ábrahám, I. Dékány: Photoluminescence enhancement of $\mathrm{ZnO}$ particles on gold coated substrates by plasmonic coupling, International Workshop on Functional Nanostructured ThinFilms, Budapest, Hungary, $13^{\text {th }}$ December 2012.

2. N. Ábrahám, E. Csapó, I. Dékány: Langmuir monolayer study of the interaction of biofunctionalized gold nanoparticles with model phospholipid membranes. 5th Szeged International Workshop on Advances in Nanoscience (SIWAN) $24^{\text {th }}-27^{\text {th }}$ October 2012 , Szeged, Hungary, Abstr. O28

3. N. Ábrahám, E. Csapó, I. Dékány: Interaction of biofunctionalized gold nanoparticles with model lipid membranes, AMSALS2012 Conference, Siófok, Hungary, $3^{\text {rd }}-6^{\text {th }}$ June 2012. Abstr. OC49

4. N. Ábrahám, I. Dékány: Enhanced photoluminescence of $\mathrm{ZnO}$ films on gold coated glass by plasmonic coupling, $25^{\text {th }}$ ECIS Conference, Berlin, Germany, $4^{\text {th }}-9^{\text {th }}$ September 2011, Abstr. 430.

5. L. Naszályi és N. Ábrahám (közös előadás), A. Ayral, Z. Hórvölgyi: Stabilized Langmuir-Blodgett films of nanoparticles for photocatalytic application, $2^{\text {nd }}$ European COST 540 WG1 Seminar, Toulouse, 2007

\section{Konferenciaszereplések / poszterek:}

6. N. Ábrahám, E. Csapó, I. Dékány: Interaction of biofunctionalized gold nanoparticles with model lipid membranes, AMSALS2012 Conference, Siófok, Hungary, $3^{\text {rd }}-6^{\text {th }}$ June 2012. Abstr. P31

7. N. Ábrahám, D. Sebők, S. Papp, L. Kőrösi and I. Dékány: Preparation and investigation of monodisperse $\mathrm{ZnO}$ particles and their Langmuir-Blodgett films, EuroNanoForum 2011, Budapest, Hungary, $30^{\text {th }}$ May - $1^{\text {st }}$ June 2011, Abstr 306

8. N. Ábrahám, D. Sebők, Sz. Papp, I. Dékány: Optical and photoluminescence properties of different sized ZnO particles, 24th ECIS Conference, Prague, Czech Republic, 5th-10th September 2010, Abstr. P4.53

9. N. Ábrahám, I. Dékány: Optical and photoluminescence characteristics of ZnO Langmuir-Blodgett films, 7. Országos Anyagtudományi Konferencia (angolul: 7th Hungarian Conference On Materials Science), Balatonkenese, 2009 okt. 11-13., Abstr.: P02

10. Á. Detrich, L. Naszályi, A. Deák. A. Ayral., N. Ábrahám., Z. Hórvölgyi: Nanoparticulate coatings: Fabrication and model investigations, PORANAL 2008 Symposium, Debrecen, 2006, Abstr. P5 
11. N. Ábrahám, L. Naszályi, A. Ayral, Z. Hórvölgyi: Preparation of nanoparticulate coatings by wet colloid chemical routes: optical and photocatalytic properties, 9th Conference on Colloid Chemistry, Siófok, Hungary, 3rd-5th October 2007, Abstr. P.1

12. Lívia Naszályi, Nóra Ábrahám, Attila L. Kovács, Péter Baranyai, Didier Cot, André Ayral and Zoltán Hórvölgyi: Post modification of Langmuir-Blodgett films of ZnO nanoparticles for improving their mechanical and chemical stability, 9th Conference on Colloid Chemistry, Siófok, Hungary, 3rd-5th October 2007, Abstr. P.48

13. N. Ábrahám, L. Naszályi Nagy, Z. Hórvölgyi: Stability experiments on multifunctional nanoparticulate coatings, XIII. International Conference on Chemistry, Cluj Napoca, Romania (XIII. Nemzetközi Vegyészkonferencia, Kolozsvár, Románia) 2007

14. L. Naszályi, N. Ábrahám, A. Deák, A. L. Kovács, A. Ayral, E. Hild, Z. Hórvölgyi: Preparation and Characterization of Nanoparticulate Langmuir-Blodgett Films with Gradient Refractive Index, 20th ECIS Conference, Budapest, Hungary 17-22 September 2006, Abstr. P6.23 


\section{FÜGGELÉK}

\section{XI.1 Diszperz rendszerek kisszögü röntgenszórására vonatkozó általános összefüggések}

Ha a röntgensugarak kolloid mérettartományban lévő részecskéken szóródnak, az inhomogenitások miatt jelentkező elektronsürüség-különbség következtében a szórt sugárzás $I$ intenzitása a szórásszög $(2 \Theta)$, illetve a szórásvektor $(h=(4 \pi / \lambda) \sin \Theta)$ függvénye $[147,148,149,150]:$

$$
I(h)=\eta^{2}(0) V \int_{0}^{\infty} 4 \pi r^{2} \gamma_{0}(r) \frac{\sin h r}{h r} d r
$$

ahol $V$ a rendszer térfogata, amelyben az elektronokon a röntgensugarak szóródása történik. A fenti egyenletben $\eta^{2}(0)$ függvény értéke a következők szerint definiálható [147149]:

$$
\eta^{2}(0)=\frac{1}{V} \int_{0}^{\infty}\left(\rho_{\mathrm{e}}(\mathrm{r})-\rho_{\mathrm{e}}\right)^{2} \mathrm{~d}^{3} \mathrm{r}
$$

ahol $\rho_{e}(r)$ az elektronsürüség-eloszlási függvény adott $\mathrm{r}$ távolságban, illetve $\rho_{e}$ az átlagos érték. Ha bevezetjük az elektronsürüség-fluktuáció fogalmát: $\eta(r)=\rho_{e}(r)-\rho_{e}$, akkor megadható a (24) egyenletben szereplö korrelációs függvény:

$$
\gamma_{0}(r)=\frac{\eta^{2}(r)}{\eta^{2}(0)},
$$

amely jelentős információt tartalmaz a szóró részecskék nagyságáról és alakjáról.

A szórásgörbe úgynevezett Porod-tartományára (amelynél $h R>1$ ), a következő összefüggés érvényes $[150,151,152,153,154,155]$ :

$$
I(h)=\eta^{2}(0) 2 \pi \frac{S}{h^{4}},
$$

ahol $S$ a részecskék felületének nagysága. A részecskék fajlagos felülete ( $V$ térfogategységre vonatkoztatva) [149-151]: 


$$
\frac{S}{V}=\pi \frac{\lim _{h \rightarrow \infty} I(h) h^{4}}{Q}=\pi \frac{K_{p}}{Q},
$$

ahol $K_{p}$ a Porod-konstans. A tömegegységre vonatkoztatott fajlagos felület $S / V$ relatív értékéből az alábbi egyenlet szerint számítható:

$$
S_{p}=\frac{S / V \times 10^{3}}{d},
$$

ahol $d$ a diszperz rendszer sürüsége $\mathrm{g} / \mathrm{cm}^{3}$-ben megadva.

A korrelációs hossz $\left(l_{c}\right)$ a szórásgörbéböl közvetlenül számítható, ha ismerjük az alábbi integrált [152-155]:

$$
l_{c}=\pi \frac{\int_{0}^{\infty} I(h) h d h}{Q} .
$$

A szórásgörbe Porod-tartományából meghatározható a részecskék tömeg- $\left(D_{m}\right)$ és felületi fraktáldimenziója $\left(D_{s}\right)$. Ha a szórásgörbe legalább egy nagyságrenden keresztül lineáris szakasszal rendelkezik $(\log I(h)=p \log h)$, akkor a $p$ meredekség értékéből adódik:

$$
D_{m}=|p|+1 \text { és } D_{s}=p+5 \text {. }
$$

\section{XI.2 Nanorészecskés filmek fajlagos tömegének meghatározása abszorbancia kalibráció és elméleti számítás alapján}

A 3-7 nm-es $\mathrm{ZnO}$ részecskékből épített többrétegü Langmuir-Blodgett filmek területegységre eső tömegét kétféle módon határoztam meg.

Az első esetben hígítási sorozatot készítettem a ZnO szolból, majd a spektrumok mérése után abszorbancia vs. koncentráció kalibrációt készítettem (65. ábra). A 3D-s koncentrációt $\left(\mathrm{mg} / \mathrm{cm}^{3}\right)$ ezután megfeleltettem 2D-s koncentrációnak, azaz fajlagos film tömegnek $\left(\mathrm{mg} / \mathrm{cm}^{2}\right)$. Ez a megfeleltetés úgy képzelhető el, hogy adott $\mathrm{ZnO}$ mennyiség ugyanannyi fényt nyel el, ha az $1 \mathrm{~cm}^{3}$ szolban van diszpergálva vagy ha egy $1 \mathrm{~cm}^{2}$ területre van leválasztva. Úgy is értelmezhető, hogy a kalibrációt tulajdonképpen nem ZnO koncentrációra, hanem $\mathrm{ZnO}$ tömegre készítjük el, amely lehet egységnyi térfogatú szolban vagy egységnyi területű filmben. A kalibrációs egyenes meghatározása után lemértem a 
$\mathrm{ZnO}$ részecskékből felépített film abszorbanciáját, majd a kalibráció alapján visszaszámolva megkaptam a $\mathrm{ZnO}$ részecskék tömegét.

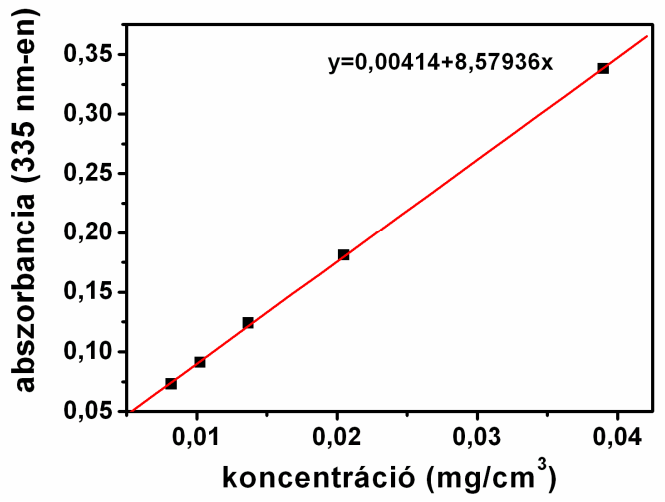

65. ábra. A ZnO szol esetén mért abszorbancia vs. koncentráció kalibrációs diagram ( $\lambda=335 \mathrm{~nm})$.

Elméleti úton is kiszámítható az egységnyi területü film tömege, ha feltételezzük, hogy a részecskék gömb alakúak, egyforma méretüek és szoros, hexagonális illeszkedésben rendezkednek el a filmben. Ez persze egy idealizált kép, amely ezeknél a részecskéknél nem fedi a valóságot, azonban becsléshez mindenképpen alkalmazható. Elsőként egy részecske köré írható hatszög területét számítottam ki a (6) egyenlettel, ennek reciproka megadja az $1 \mathrm{~cm}^{2}$-re eső részecskék számát $\left(N_{Z n O}\right)$. A részecskék mérete $(r)$ alapján kiszámítható egy részecske térfogata $\left(V_{Z n O}\right)$, ezt megszorozva a $\mathrm{ZnO}$ sürüségével $\left(\rho_{Z n O}\right)$ és a részecskék darabszámával, eredményül kapjuk az egységnyi területü film tömegét $\left(\mathrm{mg} / \mathrm{cm}^{2}\right)$ :

$$
m_{Z n O}=N_{Z n O} \rho_{Z n O} V_{Z n O}=N_{Z n O} \rho_{Z n O} \frac{4 r^{3} \pi}{3} .
$$

Ezzel egy egyrétegű film tömegét kaptuk meg, további rétegek esetén a megfelelő többszöröst kell venni. 


\section{IRODALOMJEGYZÉK}

[1] N. N. Greenwood, A. Earnshaw: Chemistry of the Elements, Butterworth-Heinemann, 2. kiadás, 1997

[2] http://www.sci.uidaho.edu/geol464-564/pdf/lectures_pdf/Lecture_5.pdf

[3] Ü. Özgür, Ya. I. Alivov, C. Liu, A. Teke, M. A. Reshchikov, S. Doğan, V. Avrutin,S.-J. Cho, H. Morkoçd: A comprehensive review of ZnO materials and devices, J. Appl. Phys. 98 (2005) 041301 .

[4] Tokyo Denpa Co., Ltd, Japán

[5] Zinc Oxide: Fundamentals, Materials and device Technology, ed. by H. Morkoc, Ü. Özgür, Wiley-VCH, 2009

[6] E. Pál, V. Hornok, A. Oszkó, I. Dékány: Hydrothermal synthesis of prism-like and flower-like $\mathrm{ZnO}$ and indium-doped $\mathrm{ZnO}$ structures, Colloid Surf A: Physicochem. Eng. Aspects 340 (2009) $1-9$.

[7] E.Pal, V. Hornok, R. Kun, A. Oszkó, T.Seemann, I. Dekany, M. Busse: Hydrothermal synthesis and humidity sensing propertty of $\mathrm{ZnO}$ nanostructures and $\mathrm{ZnO}-\mathrm{In}(\mathrm{OH}) 3$ nanosomposites. J. Colloid and Interface Sci., 378 (2012) 100-109

[8] E. Pál, V. Hornok, R. Kun, V. Chernysev, T. Seemann, I. Dékány, M. Busse, Growth of raspberry-, prism- and flower-like $\mathrm{ZnO}$ particles using template-free low-temperature hydrothermal method and their application as humidity sensors, J Nanopart Res 14 (2012) 1002

[9] L. Wang, M. Muhammed: Synthesis of zinc oxide nanoparticles with controlled morphology, J. Mater. Chem. 9 (1999) 2871-2878.

[10] F. Yuan, P. Hu, C. Yin, S. Huang, J. Li: Preparation and properties of zinc oxide nanoparticles coated with zinc aluminate, J. Mater. Chem. 13 (2003) 634-637.

[11] J. Wang, L. Gao: Synthesis and characterization of $\mathrm{ZnO}$ nanoparticles assembled in onedimensional order, Inorg. Chem. Commun. 6 (2003) 877-881.

[12] E. Pál, I. Dékány, Structural, optical and photoelectric properties of indium-doped zinc oxide nanoparticles prepared in dimethyl sulphoxide, Colloid Surf. A.: Physicochem. Eng. Aspects 318 (2008) 141-150.

[13] J. Németh, G. Rodrígez-Gattorno, D. Díaz, A. R. Vázquez-Olmos, I. Dékány: Synthesis of $\mathrm{ZnO}$ nanoparticles on a clay mineral surface in dimethyl sulfoxide medium, Langmuir 20 (2004) 2855-2860.

[14] S.K. Na Ayudhya, P. Tonto, O. Mekasuwandumrong, V. Pavarajarn, P. Praserthdam: Solvothermal synthesis of $\mathrm{ZnO}$ with various aspect ratios using organic solvents, Cryst. Growth Des. 6 (2006) 2446-2450.

[15 ] F. Rataboul, C. Nayral, M-J. Casanove, A. Maisonnat, B. Chaudret: Synthesis and characterization of monodisperse zinc and zinc oxide nanoparticles from the organometallic precursor $\left[\mathrm{Zn}\left(\mathrm{C}_{6} \mathrm{H}_{11}\right)_{2}\right]$, J. Organomet. Chem. 643-644 (2002) 307-312.

[16] P. X. Gao, Y. Ding, W. J. Mai, W.L. Hughes, C.S. Lao, Z.L. Wang: Conversion of zinc oxide nanobelts into superlattice-structured nanohelices, Science 309 (2005) 1700-1704.

[17] S. Ashtaputre, S. Marathe, S. Kulkarni: Doughnut-shaped zinc oxide particles, J Mater Sci 42 (2007) 9990-9994. 
[18]The-Long Phan, S.C.Yu, R.Vincent, N.H.Dan, W.S.Shi: Photoluminescence properties of various CVD-grown ZnO nanostructures, J. Lumin. 130 (2010) 1142-1146.

[19] http://www.phy.bris.ac.uk/groups/electron_microscopy, Bristol Egyetem, Fizikai Intézet, Elektronmikroszkóp Csoport honlapja

[20] L. Spanhel, M. A. Anderson: Semiconductor clusters in the sol-gel process: quantized aggregation gelation, and crystal growth in concentrated $\mathrm{ZnO}$ colloids, J. Am. Chem. Soc. 113 (1991) 2826-2833.

[21] E. A. Meulenkamp: Synthesis and growth of ZnO nanoparticles, J. Phys. Chem. B 102 (1998) 5566-5572.

[22] D. Sun, M. Wong, L. Sun, Y. Li, N. Miyatake, H.-J. Sue: Purification and stabilization of colloidal ZnO nanoparticles in methanol, J Sol-Gel Sci. Technol. 43 (2007) 237-243.

[23] C.-H. Hung, W.-T. Whang: Effect of surface stabilization of nanoparticles on luminescent characteristics in $\mathrm{ZnO} /$ poly(hydroxyethyl methacrylate) nanohybrid films, J. Mater. Chem. 15 (2005) 267-274.

[24] Y.L. Wu, A.I.Y. Tok, F.Y.C. Boey, X.T. Zeng, X.H. Zhang: Surface modification of ZnO nanocrystals, Appl. Surf. Sci. 253 (2007) 5473-5479.

[25] CH. H. Kuhn, R. Lipski, F. Seeler, D. Mauder G. Müller, L. Spanhel: New Variations in the Colloidal Route to ErIII@ZnO Nanocrystals and Films, J. Sol-Gel Sci. Techn. 26 (2003) 499_ 503.

[26] L. Guo, S. Yang, Synthesis and characterization of poly(vinylpyrrolidone)-modified zinc oxide nanoparticles, Chem. Mater. 12 (2000) 2268-2274.

[27] R. Viswanatha, S. Sapra, B. Satpati, P. V. Satyam, B. N. Devb, D. D. Sarma, Understanding the quantum size effects in $\mathrm{ZnO}$ nanocrystals, J. Mater. Chem. 14 (2004) 661-668.

[28] B. Krishnan, L. Irimpan, V.P.N. Nampoor, V. Kumar, Synthesis and nonlinear optical studies of nano $\mathrm{ZnO}$ colloids, Physica E 40 (2008) 2787-2790.

[29] L. Irimpan, B. Krishnan, A Deepthy, V P N Nampoori, P Radhakrishnan, Excitation wavelength dependent fluorescence behaviour of nano colloids of $\mathrm{ZnO}$, J. Phys. D: Appl. Phys. 40 (2007) 5670-5674.

[30] X.L. Cheng, H. Zhao, L.H. Huo, S. Gao, J.G. Zhao, ZnO nanoparticulate thin film: preparation, characterization and gas-sensing property, Sens. Actuators B 102 (2004) 248-252.

[31] M. Vafaee, M. Sasani Ghamsari, Preparation and characterization of $\mathrm{ZnO}$ nanoparticles by a novel sol-gel route, Mater. Lett. 61 (2007) 3265-3268.

[32] A. Chittofrati, E. Matijevic: Uniform Particles of Zinc-oxide of Different Morphologies, Colloid Surf. 48 (1990) 65-78.

[33] Q.P. Zhong, E. Matijevic: Preparation of uniform zinc oxide colloids by controlled double-jet precipitation, J. Mater. Chem. 6 (1996) 443-447.

[34] H. Jiang, JQ. Hu, F. Gu, CZ. Li: Large-scaled, uniform, monodispersed ZnO colloidal microspheres, J. Phys. Chem. C 112 (2008) 12138-12141.

[35] M. Inoguchi, K. Suzuki, K. Keisuke, T. Hiroshi, Y. Sakabe: Monodispersed and WellCrystallized Zinc Oxide Nanoparticles Fabricated by Microemulsion Method, J. Am. Chem. Soc. 91 (2008) 3850-3855.

[36] C. Feldmann: Polyol-mediated synthesis of nanoscale functional materials Solid State Sciences 7 (2005) 868-873. 
[37] C. Feldmann and H.-O. Jungk: Polyol-Mediated Preparation of Nanoscale Oxide Particles, Angew. Chem. Int. Ed. 40 (2001) 359-362.

[38] Fine particles, Synthesis, Characterization and Mechanisms of Growth, ed. by T. Sugimoto, Surfactant Science Series, Volume 92, Marcel Dekker Inc., New York, 2000

[39] D. Jezequel, J. Guenot, N. Jouini, F. Fivet: Preparation and morphological characterizaton of fine, spherical, monodisperse particles of ZnO, Materials Science Forum 152-153 (1994) 339342.

[40] E. W. Seelig, B. Tang, A. Yamilov, H. Cao, R.P.H. Chang: Self-assembled 3D photonic crystals from ZnO colloidal spheres, Materials Cemistry and Physics 80 (2003) 257-263.

[41] Y.Y. Tay, S. Li, F. Boey, Y.H. Cheng, M.H. Liang: Growth mechanism of spherical ZnO nanostructures synthesized via colloid chemistry, Physica B 394 (2007) 372-376.

[42] L. Spanhel, Colloidal ZnO nanostructures and functional coatings: A survey, J Sol-Gel Sci. Technol. 39 (2006) 7-24.

[43] A. Janotti, C. G Van de Walle: Fundamentals of zinc oxide as a semiconductor, Rep. Prog. Phys. 72 (2009) 126501

[44] Z. L. Wang: Zinc oxide nanostructures: growth, properties and applications, J. Phys.: Condens. Matter 16 (2004) R829-R858

[45] S. Dutta, S. Chattopadhyay, A. Sarkar, M. Chakrabarti, D. Sanyal, D. Jana: Role of defects in tailoring structural, electrical and optical properties of $\mathrm{ZnO}$, Progress in Materials Science 54 (2009) 89-136.

[46] L. Schmidt-Mende, J. L. MacManus-Driscoll: $\mathrm{ZnO}$ - nanostructures, defects, and devices, Materials Today 10 (2007) 40-48.

[47] D. W., Bahnemann; C. Kormann; M. R. Hoffmann: Preparation and Characterization of Quantum Size Zinc Oxide: A Detailed Spectroscopic Study J. Phys. Chem. 91 (1987) 3789_ 3798.

[48] J. Tauc, Optical properties of amorphous semiconductors, in: J. Tauc (Ed.), Amorphous and liquid semiconductors, Plenum Press, New York, 1974, pp. 159-220.

[49] L. Brus: Electronic wave functions in semiconductor clusters: experiment and theory, J. Phys. Chem. 90 (1986) 2555-2560.

[50] A. van Dijken, E.A. Meulenkamp, D. Vanmaekelbergh, A. Meijerink: Identification of the transition responsible for the visible emission in $\mathrm{ZnO}$ using quantum size effects, Journal of Luminescence 90 (2000) 123-128.

[51] J. Liqiang, Q. Yichun, W. Baiqi, L. Shudan, J. Baojiang, Y. Libin, F. Wei, F. Honggang, Sun Jiazhong: Review of photoluminescence performance of nano-sized semiconductor materials and its relationships with photocatalytic activity, Solar Energy Mater. Solar Cells 90 (2006) 1773-1787.

[52] A. van Dijken, E. A. Meulenkamp, D. Vanmaekelbergh, A. Meijerink: The Kinetics of the Radiative and Nonradiative Processes in Nanocrystalline ZnO Particles upon Photoexcitation, J. Phys. Chem. B 104 (2000) 1715-1723.

[53] A. van Dijken, E. A. Meulenkamp, D. Vanmaekelbergh, A. Meijerink, The luminescence of nanocrystalline $\mathrm{ZnO}$ particles: the mechanism of the ultraviolet and visible emission, J. Lumin. 87-89 (2000) 454-456.

[54] L. Zhang, L. Yin, C. Wang, N. lun, Y. Qi, D. Xiang: Origin of Visible Photoluminescence of ZnO Quantum Dots: Defect-Dependent and Size-Dependent, J. Phys. Chem. C 114 (2010) 9651-9658. 
[55] K. Vanheusden, W. L. Warren, C. H. Seager, D. R. Tallant, J. A. Voigt, B. E. Gnade: Mechanisms behind green photoluminescence in $\mathrm{ZnO}$ phosphor powders, J. Appl. Phys. 79 (10) 7983-7990 1996

[56] D. C. Reynolds, D. C. Look, B. Jogai, J. E. Van Nostrand, R. J. J. Jones: Source of the yellow luminescence band in GaN grown by gas-source molecular beam epitaxy and the green luminescence band in single crystal ZnO, Solid State Commun. 106 (1998) 701-704.

[57] Y. H. Leung, A. B. Djurisic, Z. T. Liu, D. Li, M. Hai Xie, W. Kin Chan: Defect photoluminescence of $\mathrm{ZnO}$ nanorods synthesized by chemical methods, Journal of Physics and Chemistry of Solids 69 (2008) 353-357.

[58] C. H. Ahn, Y. Y. Kim, D. C. Kim, S. K. Mohanta, H K. Cho: A comparative analysis of deep level emission in $\mathrm{ZnO}$ layers deposited by various methods, Journal of Applied Physics 105, 013502 (2009)

[59] Lin, B. X., Fu, Z. X., Jia, Y. B.: Green luminescent center in undoped zinc oxide films deposited on silicon substrates, Appl. Phys. Lett. 79 (2001) 943-945.

[60] F. A. Kröger, The Chemistry of Imperfect Crystals, $2^{\text {nd }}$ Edition, North Holland, Amsterdam (1974) 73

[61] P.S. Xu, Y.M. Sun, C.S. Shi, F.Q. Xu, H.B. Pan: The electronic structure and spectral properties of $\mathrm{ZnO}$ and its defects, Nuclear Instruments and Methods in Physics Research B199 (2003) 286-290

[62] A. van Dijken, J. Makkinje, A. Meijerink, The influence of particle size on the luminescence quantum efficiency of nanocrystalline ZnO particles, J. of Lumin. 92 (2001) 323-328.

[63] A. van Dijken, E. A. Meulenkamp, D. Vanmaekelbergh, A. Meijerink, Influence of adsorbed oxygen on the emission properties of nanocrystalline $\mathrm{ZnO}$ particles, J. Phys. Chem. B 104 (2000) 4355-4360.

[64] Y. Liu, C. Lü, M. Li, J. Liu, L. Zhang, J. Zhang, B. Yang, Transparent and stable photoluminescent sol-gel hybrid films by incorporating surface modified $\mathrm{ZnO}$ nanocrystals, Thin Solid Films 516 (2008) 8507-8512.

[65] L. Guo, S. Yang, Highly monodispersed polymer-capped $\mathrm{ZnO}$ nanoparticles: preparation and optical properties, Appl. Phys. Lett. 76 (2000) 2901-2903.

[66] C. L. Yang, J. N. Wang, W. K. Ge, L. Guo, S. H. Yang, D. Z. Shen, Enhanced ultraviolet emission and optical properties in polyvinyl-pyrrolidone surface modified $\mathrm{ZnO}$ quantum dots, J. Appl. Phys. 90 (2001) 4489-4493.

[67] L. Irimpan, V. P. N. Nampoori, P. Radhakrishnan, A. Deepthy, B. Krishnan: Size dependent fluorescence spectroscopy of nanocolloids of ZnO, J. Appl. Phys 102 (2007) 063524

[68] Sefan A. Maier: Plasmonics: Fundamentals and Application, 2007 Springer Science and Business Media LLC

[69] R. Sardar, A. M. Funston, P. Mulvaney, Royce W. Murray: Gold Nanoparticles: Past, Present, and Future, Langmuir 2009, 25(24), 13840-13851.

[70] J. Perez-Juste, I. Pastoriza-Santos, L. M. Liz-Marza, P. Mulvaney: Gold nanorods: Synthesis, characterization and applications, Coordination Chemistry Reviews 249 (2005) 1870-1901.

[71] Kyeong-Seok Lee, Mostafa A. El-Sayed: Gold and Silver Nanoparticles in Sensing and Imaging: Sensitivity of Plasmon Response to Size, Shape, and Metal Composition, J. Phys. Chem. B 2006, 110, 19220-19225.

[72] G. Mie: Beiträge zur Optik trüber Medien, speziell colloidaler Metallösugen, Ann. Phys. 330 (1908) 377-445. 
[73] Elisa Hutter, Janos H. Fendler: Exploitation of localised surface plasmon resonance, Adv. Mater 16 (2004) No 19.

[74] Csapó Edit (MTA-SZTE Szupramolekuláris és Nanoszerkezetü Anyagok Kutatócsoport), részben közölt redmények; Ag gömb: E. Csapó, R. Patakfalvi, V. Hornok,L.T. Tóth, Á. Sipos, A. Szalai, M. Csete and I. Dékány : Effect of $\mathrm{pH}$ on stability and plasmonic properties of cysteine-functionalized silver nanoparticle dispersions, Colloids and Surfaces B., 98 (2012) 43 49; Au gömb: E.Csapó, A. Oszkó, E.Varga, Á.Juhász, N. Buzás, L-Körösi, A.Majzik I. Dékány: Syhtesis and characterization of $\mathrm{Ag} / \mathrm{Au}$ alloy and core( $\mathrm{Ag})$-shell( $\mathrm{Au}$ ) nanoparticles, Colloids and Surfaces A. 415 (2012) 281-287, Au rúd: nem publikált

[75] Stephan Link, Mostafa A. El-Sayed: Size and Temperature Dependence of the Plasmon Absorption of Colloidal Gold Nanoparticles, J. Phys. Chem. B 1999, 103, 4212-4217.

[76] S. Link, Z. L. Wang, M. A. El-Sayed: Alloy Formation of Gold-Silver Nanoparticles and the Dependence of the Plasmon Absorption on Their Composition, J. Phys. Chem. B 103 (1999) 3529-3533.

[77] R. B. M. Schasfoort, A. J. Tudos, Handbook of Surface Plasmon Resonance, The Royal Society of Chemistry, Cambridge, UK, 2008.

[78] Amanda J. Haes, Richard P. Van Duyne: A unified view of propagating and localized surface plasmon resonance biosensors, Anal Bioanal Chem 379 (2004) 920-930.

[79] Prashant K. Jain, Xiaohua Huang, Ivan H. El-Sayed, Mostafa A. El-Sayed: Review of Some Interesting Surface Plasmon Resonance-enhanced Properties of Noble Metal Nanoparticles and Their Applications to Biosystems, Plasmonics 2 (2007) 107-118.

[80] P. K. Jain, I. H. El-Saved, M. A. El-Sayed: Au nanoparticles target cancer, Nano Today 2 (2007) 18-29.

[81] Dakrong Pissuwan, Stella M. Valenzuela. Michael B. Cortie: Therapeutic possibilities of plasmonically heated gold nanoparticles, TRENDS in Biotechnology 24 (2006) 62-67.

[82] Santanu Pyne, Gobinda Prasad Sahoo, Dipak Kumar Bhui, Harekrishna Bar, Priyanka Sarkar, Sadhan Samanta, Ashim Maity, Ajay Misra: Enhanced photocatalytic activity of metal coated ZnO nanowires, Spectrochimica Acta Part A 93 (2012) 100- 105.

[83] Ma. De Lourdes Ruiz Peralta, U. Pal, R. Sánchez Zeferino: Photoluminescence (PL) Quenching and Enhanced Photocatalytic Activity of Au-Decorated ZnO Nanorods Fabricated through Microwave-Assisted Chemical Synthesis, ACS Appl. Mater. Interfaces 4 (2012) 4807-4816.

[84] Adam Dorfman, Nitin Kumar, Jong-in Hahm: Highly Sensitive Biomolecular Fluorescence Detection Using Nanoscale ZnO Platforms, Langmuir 22 (2006) 4890-4895.

[85] X. Gu, T. Qiu, W. Zhang, P. K Chu: Light-emitting diodes enhanced by localized surface plasmon resonance Nanoscale Research Letters 6 (2011) 199.

[86] A. P. Abiyasa, S. F. Yu, S. P. Lau, Eunice S. P. Leong, and H. Y. Yang: Enhancement of ultraviolet lasing from Ag-coated highly disordered $\mathrm{ZnO}$ films by surface-plasmon resonance, Appl. Phys. Lett. 90 (2007) 231106

[87] C. W. Cheng, E. J. Sie, B. Liu, C. H. A. Huan, T. C. Sum, H. D. Sun, H. J. Fan: Surface plasmon enhanced band edge luminescence of $\mathrm{ZnO}$ nanorods by capping $\mathrm{Au}$ nanoparticles, Appl. Phys. Lett. 96 (2010) 071107

[88] H. Y. Lin, C. L. Cheng, Y. Y. Chou, L. L. Huang, Y. F. Chen, K. T. Tsen: Enhancement of band gap emission stimulated by defect loss, Optics Express 14 (2006) 2372-2379. 
[89] Jisun Im, Jagdeep Singh, Jason W. Soares, Diane M. Steeves, and James E. Whitten: Synthesis and Optical Properties of Dithiol-Linked ZnO/Gold Nanoparticle Composites, J. Phys. Chem. C 115 (2011) 10518-10523.

[90] Moumita Mahanti, Durga Basak: Highly enhanced UV emission due to surface plasmon resonance in Ag-ZnO nanorods, Chemical Physics Letters 542 (2012) 110-116.

[91] Lanlan Sun, Dongxu Zhao, Zhiming Song, Chongxin Shan, Zhenzhong Zhang, Binghui Li, Dezhen Shen: Gold nanoparticles modified $\mathrm{ZnO}$ nanorods with improved photocatalytic activity, Journal of Colloid and Interface Science 363 (2011) 175-181.

[92] Myung-Ki Lee, Tae Geun Kim, Woong Kim, Yun-Mo Sung: Surface Plasmon Resonance (SPR) Electron and Energy Transfer in Noble Metal-Zinc Oxide Composite Nanocrystals, J. Phys. Chem. C 112 (2008) 10079-10082.

[93] V. Subramanian, E. E. Wolf, P. V. Kamat: Green Emission to Probe Photoinduced Charging Events in $\mathrm{ZnO}-\mathrm{Au}$ Nanoparticles. Charge Distribution and Fermi-Level Equilibration, J. Phys. Chem. B 107 (2003) 7479-7485.

[94] Xuehong Li, Yang Zhang, Xijun Ren: Effects of localized surface plasmons on the photoluminescence properties of Au-coated ZnO films, Optics Express 17 (2009) 8735-8740.

[95] B.J. Lawrie, R.F. Haglund Jr, R. Mu: Enhancement of $\mathrm{ZnO}$ photoluminescence by localized and propagating surface plasmons, Optics Express 17 (2009) 2565-2572.

[96] Richard F. Haglund Jr, Benjamin J. Lawrie, Richard Mu: Coupling of photoluminescent centers in $\mathrm{ZnO}$ to localized and propagating surface plasmons, Thin Solid Films 518 (2010) 4637-4643.

[97] Jaeil Lee, Hyeong Seop Shim, Myeongsoon Lee, Jae Kyu Song, Dongil Lee: Size-Controlled Electron Transfer and Photocatalytic Activity of $\mathrm{ZnO}-\mathrm{Au}$ Nanoparticle Composites, J. Phys. Chem. Lett. 2 (2011) 2840-2845.

[98] Lanlan Sun, Dongxu Zhao, Zhiming Song, Chongxin Shan, Zhenzhong Zhang, Binghui Li, Dezhen Shen: Gold nanoparticles modified $\mathrm{ZnO}$ nanorods with improved photocatalytic activity, Journal of Colloid and Interface Science 363 (2011) 175-181.

[99] P. V. Braun, P.Wiltzius, Microporous materials - Electrochemically grown photonic crystals, Nature 402 (1999) 603.

[100] J. D. Joannopoulos, P. R. Villeneuve, S. Fan: Photonic crystals: putting a new twist on light, Nature, 386 (1997) 143-149.

[ 101 ] O. D. Velev, E.W. Kaler: Structured Porous Materials via Colloidal Crystal Templating: From Inorganic Oxides to Metals, Adv. Mater. 12 (2000) 531-534.

[102]Younan Xia, Byron Gates, Yadong Yin, Yu Lu: Monodispersed Colloidal Spheres: Old Materials with New Applications, Adv. Mater. 12 (2000) 693-713.

[103] O. Velev, S. Gupta: Materials fabricated by micro and nanoparticle assembly - The challenging path from science to engineering, Adv. Mater. 21 (2009) 1897-1905.

[104] Hongta Yanga, Peng Jianga, Bin Jiang: Vapor detection enabled by self-assembled colloidal photonic crystals, Journal of Colloid and Interface Science 370 (2012) 11-18.

[105] B. G. Prevo, Y. Hwang, O. D. Velev: Convective Assembly of Antireflective Silica Coatings with Controlled Thickness and Refractive Index Chem., Mater. 17 (2005) 3642-3651. 
[106] Y. Yin, Y. Lu, B. Gates, Y. Xia: Template-Assisted Self-Assembly: A Practical Route to

Complex Aggregates of Monodispersed Colloids with Well-Defined Sizes, Shapes, and Structures J. Am. Chem. Soc. 123 (2001) 8718-8729.

[107] A. Deák, B. Bancsi, A.L. Tóth, A.L. Kovács, Z. Hórvölgyi: Complex Langmuir-Blodgett films from silica nanoparticles: An optical spectroscopy study, Colloids and Surfaces A: Physicochem. Eng. Aspects 278 (2006) 10-16.

[108] M. Szekeres, O. Kamalin, R. A. Schoonheydt, K. Wostyn, K. Clays, A. Persoons, I. Dékány: Ordering and optical properties of monolayers and multilayers of silica spheres deposited by the Langmuir-Blodgett method, J. Mater. Chem. 12 (2002) 3268-3274.

[109] G. Zhavnerko, G. Marletta: Developing Langmuir-Blodgett strategies towards practical devices, Materials Science and Engineering B 169 (2010) 43-48.

[110] N. D. Denkov, O. D. Velev, P. A. Kralchevsky, I. B. Ivanov, H. Yoshimura, K. Nagayama: Two-Dimensional Crystallization, Nature 361 (1993) 26.

[111] P. Jiang, J. F. Bertone, K. S. Hwang, V. L. Colvin: Single-Crystal Colloidal Multilayers of Controlled Thickness, Chem. Mater. 11 (1999) 2132-2140.

[112]Z. Yuan, D. B. Burckel, P. Atanassov, H. Fan: Convective self-assembly to deposit supported ultra-thin mesoporous silica films, J. Mater. Chem., 16 (2006) 4637-4641.

[113] H. Wang, K.P.Yan, J.Xie, M.Duan: Fabrication of ZnO colloidal photonic crystal by spincoating method, Materials Science in Semiconductor Processing 11 (2008) 44-47.

[114] B. G. Prevo, O. D. Velev: Controlled, Rapid Deposition of Structured Coatings from Microand Nanoparticle Suspensions, Langmuir 20 (2004) 2099-2107.

[115] Franklin Kim, Serena Kwan, Jennifer Akana, Peidong Yang: Langmuir-Blodgett Nanorod Assembly, J. Am. Chem. Soc. 123 (2001) 4360-4361.

[116] W. Stöber, A. Fink, E. Bohn: Controlled growth of monodisperse silica spheres in the micron size range, J. Coll. Interface Sci. 26 (1968) 62-69.

[117] Yong-Hong Ye, Theresa S. Mayer, Iam-Choon Khoo, Ivan B. Divliansky, Neal Abrams, Thomas E. Mallouk: Self-assembly of three-dimensional photonic-crystals with air-core line defects, J. Mater. Chem., 12 (2002) 3637-3639.

[118] I. Langmuir: The Constitution and Fundamental Properties of Solids and Liquids II. Liquids, J. Am. Chem.Soc 39 (1917) 1984-1906.

[119] K. B. Blodgett: Films Built by Depositing Successive Monomolecular Layers on a Solid Surface, J. Am. Chem. Soc. 57 (1938) 1007-1022.

[120] Langmuir-Blodgett-filmek, Kiss Éva, A kémia újabb eredményei 95., Akadémiai Kiadó, 2006

[121] M. C. Petty, Langmuir-Blodgett films. An introduction.Cambridge University Press, Cambridge, 1996.

[122] Hórvölgyi Zoltán: Anorganikus részecskék folyadék-fluidum hattárrétegbeli diszperziói és szilárd hordozós filmjei, MTA doktori értekezés, 2011.

[123] Nagyné Naszályi Lívia: Preparation and characterization of functional nanostructured thin layers composed of silica, $\mathrm{ZnO}$ and core/shell silica/ZnO particles, $\mathrm{PhD}$ disszertábió, BME, 2008 
[124] L. Naszályi, A. Deák, E. Hild, A. Ayral, A.L. Kovács, Z. Hórvölgyi: Langmuir-Blodgett films composed of size-quantized $\mathrm{ZnO}$ nanoparticles: Fabrication and optical characterization, Thin Solid Films, 515 (2006) 2587-2595.

[125] E. Hild, A. Deák, L. Naszályi, Ö. Sepsi, N. Ábrahám, Z. Hórvölgyi: Use of the optical admittance function and its WKB approximation to simulate and evaluate transmittance spectra of graded-index colloidal films, Journal of Optics A: Pure and Applied Optics 9 (2007), 920930.

[126] L. Naszályi Nagy, N. Ábrahám, E. Hild, A. L. Kovács, A. van der Lee, V. Rouessac, D. Cot, A. Ayral, Z. Hórvölgyi: Zinc oxide LB films with improved antireflective, photocatalytic and mechanical properties, Progr. Coll, Polymer Sci, Progr Coll Polym Sci 135 (2008) 107-118.

[127] L. Naszályi Nagy, N. Ábrahám, E. Hild, D. Cot, A. Ayral, Z. Hórvölgyi: Complex LangmuirBlodgett films of $\mathrm{SiO} 2$ and $\mathrm{ZnO}$ nanoparticles with advantageous optical and photocatalytical properties, Langmuir 24 (2008) 12575-12580.

[128] M. P. Shortell, H. W. Liu, H. Zhu, E. A. Jaatinen, E. R. Waclawik: Formation of OneDimensional Capped $\mathrm{ZnO}$ Nanoparticle Assemblies at the Air/Water Interface, Langmuir 26 (2010) 14472-14478.

[129] A. Azam, S. M. Muhamed, A. S. Ahmed, M.L. Singla, A.H. Naqvi: The kinetics of Langmuir-Blodgett $\mathrm{ZnO}$ nano-film deposition for sensing electrodes, Materials Letters 65 (2011) 2721-2723.

[130] A. Schweikart, A. Fery: Controlled wrinkling as a novel method for the fabrication of patterned surfaces, Microchim Acta (2009) 165:249-263.

[131] A. Schweikart, . Pazos-Perez, R. A. Alvarez-Puebla, A. Fery: Controlling inter-nanoparticle coupling bywrinkle-assisted assembly, Soft Matter 7 (2011) 4093-4100.

[132] M. Pretzl, A. Schweikart, C. Hanske, A. Chiche, U. Zettl, A. Horn, A. Böker, A. Fery: A Lithography-Free Pathway for Chemical Microstructuring of Macromolecules from Aqueous Solution Based on Wrinkling, Langmuir 24 (2008) 12748-12753.

[133] A. Schweikart, A. Fortini, A. Wittemann, M. Schmidt, A. Fery: Nanoparticle assembly by confinement in wrinkles: experiment and simulations Soft Matter 6 (2010) 5860.

[134] M. Müller, M. Karg, A. Fortini, T. Hellweg, A. Fery: Wrinkle-assisted linear assembly of hard-core/soft-shell particles: impact of the soft shell on the local structure Nanoscale 4 (2012) 2491-2499.

[135] N. Pazos-Perez, W. Ni, A. Schweikart, R. A. Alvarez-Puebla, A. Fery, L M. Liz-Marzan, Chem. Sci. Highly uniform SERS substrates formed by wrinkle-confined drying of gold colloids 1 (2010) 174-178.

[136] J. Turkevich: Colloidal Gold. Part I., Gold Bulletin, 18 (1985) 86-91.

[137] A. Majzik, R. Patakfalvi, V. Hornok, I. Dékány: Growing and stability of gold nanoparticles and their functionalization by cysteine, Gold Bulletin 42 (2009) No 2.

[138]A. Majzik, L. Fülöp, E. Csapó, F. Bogár, T. Martinek, B. Penke, G. Bíró, I. Dékány: Functionalization of gold nanoparticles with amino acid, $\beta$-amyloid peptides and fragment, Colloids and Surfaces B: Biointerfaces 81 (2010) 235-241.

[139] M. Müller, M. Karg, A. Fortini, T. Hellweg, A. Fery:Wrinkle-assisted linear assembly of hard-core/soft-shell particles: impact of the soft shell on the local structure, Nanoscale, 2012, 4, 2491-2499.

[140] Folyadékszorpció és immerziós nedvesedés hidrofil/hidrofób felületeken, Dékány Imre, A kémia újabb eredményei 76., Akadémiai Kiadó, 1993. 
[141] G. N. Lewis: The atom and the molecule, J. Am. Chem. Soc. 38 (1916) 762-785.

[142] Lakowicz, J. Anal. Biochem: Radiative decay engineering 5: metal-enhanced fluorescence and plasmon emission 337 (2005) 171-194.

[143] Xuehong Li, Yang Zhang, Xijun Ren: Effects of localized surface plasmons on the photoluminescence properties of Au-coated ZnO films, Opt. Express 2009, 17, 8735-8740

[144] D. Sebők, T. Szabó, I. Dékány: Optical properties of zinc peroxide and zinc oxide multilayer nanohybrid films, Appl. Surf. Sci. 255 (2009) 6953-6962.

[145] E. Hild, A. Deák, L. Naszályi, Ö. Sepsi, N. Ábrahám, Z. Hórvölgyi: Use of the optical admittance function to stimulate and evaluate transmittance spectra of graded-index colloidal films, J. Optics A: Pure and Appiled Optics 9 (2007) 920-930.

[146] A. N. Gruzintsev, G. A. Emelchenko, V. M. Masalov: Photoluminescence of ZnO Infiltrated into a Three-Dimensional Photonic Crystal, Semiconductors 43 (2009) 1017-1022.

[147] O. Glatter, O. Kratky: Small-Angle X-ray Scattering; Academic Press: New York, 1982.

[148] A. Guinier, G. Fournet: Small-Angle Scattering of X-rays; J Wiley: New York, 1955.

[149] G. Porod: Die Röntgenkleinwinkelstreuung von dichtgepackten kolloiden Systemen I. Teil (X-ray low angle scattering of dense colloid systems. Part I.), Kolloid-Zeitschrift 124 (1951) 83114.

[150] O. Kratky: Diffuse Röntgenkleinwinkelstreuung Bestimmung von Größe und Gestalt von Kolloidteilchen und Makromolekülen, Angew Chem. 72 (1960) 467-482.

[151] O. Kratky, P. Laggner: X-Ray Small-Angle Scattering, Encyclopedia of Physical Science and Technology 14 (1987) 693.

[152] P.W. Schmidt, D. Avnir, D. Levy, A. Hohr: Small-angle x-ray scattering from the surfaces of reversed-phase silicas: Power-law scattering exponents of magnitudes greater than four. $\mathrm{J}$. Chem. Phys. 94 (1991) 1474-1479.

[153] J.A. Hurd, D.W. Schaefer, J.E. Martin: Surface and mass fractals in vapor-phase aggregates, Phys. Rev. A 35 (1987) 2361-2364.

[154] P. Zipper, A. Janosi, E. Wrentschur, P.A. Abuja: Small-angle and wide-angle X-ray scattering investigations of injection-molded polypropylene, Journal of Applied Crystallography. 24 (1991) 702-708.

[155] M. Kriechbaum, G. Degovics, J. Tritthardt: Fractal structure of Portland cement paste during age hardening analyzed by small-angle x-ray scattering, Progress in Colloid and Polimer Science. 79 (1989) 101-105. 